\title{
Principal Insects Affecting Tobacco Plants in the Field *
}

\author{
by \\ Peter A. Edde \\ Altria Client Services LLC, Research Development and Engineering, 601 East Jackson Street, Richmond, VA 23219, USA
}

\section{SUMMARY}

Tobacco, Nicotiana tabacum, is a high-value crop grown in many temperate and tropical countries of the world. Several insects attack tobacco throughout the season, from transplant production, growth in the field, during storage, and in the marketed product. This review focuses on economically important insects of the seedling tobacco or the growing crop in major tobacco-producing regions of the world. The species covered herein are tobacco aphid, black cutworm, tobacco budworm, tobacco hornworm, tobacco flea beetle, thrips, Japanese beetle, and tobacco wireworm. The occurrence and economic importance of these insects vary from region to region.

For each insect discussed, the following information is provided: the scientific name and taxonomic position of the insect; its geographical distribution; the stage that causes the damage and plant hosts; a brief discussion on classification and description of the species; a summary of the biology and ecology; details regarding pest management, which include scouting-/monitoring methods, action threshold, cultural (non-chemical) methods, natural enemies, and chemical control. In addition, a concluding paragraph is presented on insect pest management for tobacco. [Beitr. Tabakforsch. Int. 28 (2018) 117-165]

\section{KEYWORDS}

Tobacco; field insect pests; tobacco aphid; black cutworm; tobacco budworm; tobacco hornworm; tobacco flea beetle; thrips; Japanese beetle; and tobacco wireworm.

\section{ZUSAMMENFASSUNG}

Tabak, Nicotiana tabacum, ist eine hochwertige Pflanze, die in vielen Ländern der Welt mit gemäßigtem und tropischem Klima angebaut wird. Verschiedene Insekten greifen die Tabakpflanze während der gesamten Saison an, von der Produktion von Setzlingen, während des Wachstums auf dem Feld, während der Lagerung und im fertigen Produkt. Diese Übersicht konzentriert sich auf Insekten, die gravierende wirtschaftliche Schäden am jungen und heranwachsenden Tabak verursachen, indem sie den TabakKeimling oder die wachsende Pflanze in wichtigen tabakproduzierenden Regionen der Welt befallen. Bei den hier behandelten Arten handelt es sich um Tabakblattläuse, schwarze Eulenfalter, Tabakknospenwürmer, Tabakschwärmer, Tabakflohkäfer, Thripse, Japanische Käfer und Tabakdrahtwürmer. Das Vorkommen und die wirtschaftliche Bedeutung dieser Insekten variieren von Region $\mathrm{zu}$ Region.

Für jedes besprochene Insekt werden die folgenden Informationen bereitgestellt: der wissenschaftliche Name und die taxonomische Position des Insekts; seine geografische Verteilung; das Stadium, das den Schaden verursacht, und die Pflanzenwirte; eine kurze Diskussion über die Klassifizierung und Beschreibung der Arten; eine Zusammenfassung der Biologie und Ökologie; und Details bezüglich des Schädlingsmanagements, die Scouting-/ Überwachungsmethoden, Aktionsschwellenwerte, kulturelle (nicht-chemische) Methoden, natürliche Feinde und chemische Kontrolle umfassen. Darüber hinaus wird ein abschließender Absatz zum Thema Schädlingsbekämpfung bei Tabak präsentiert. [Beitr. Tabakforsch. Int. 28 (2018) 117-165] 


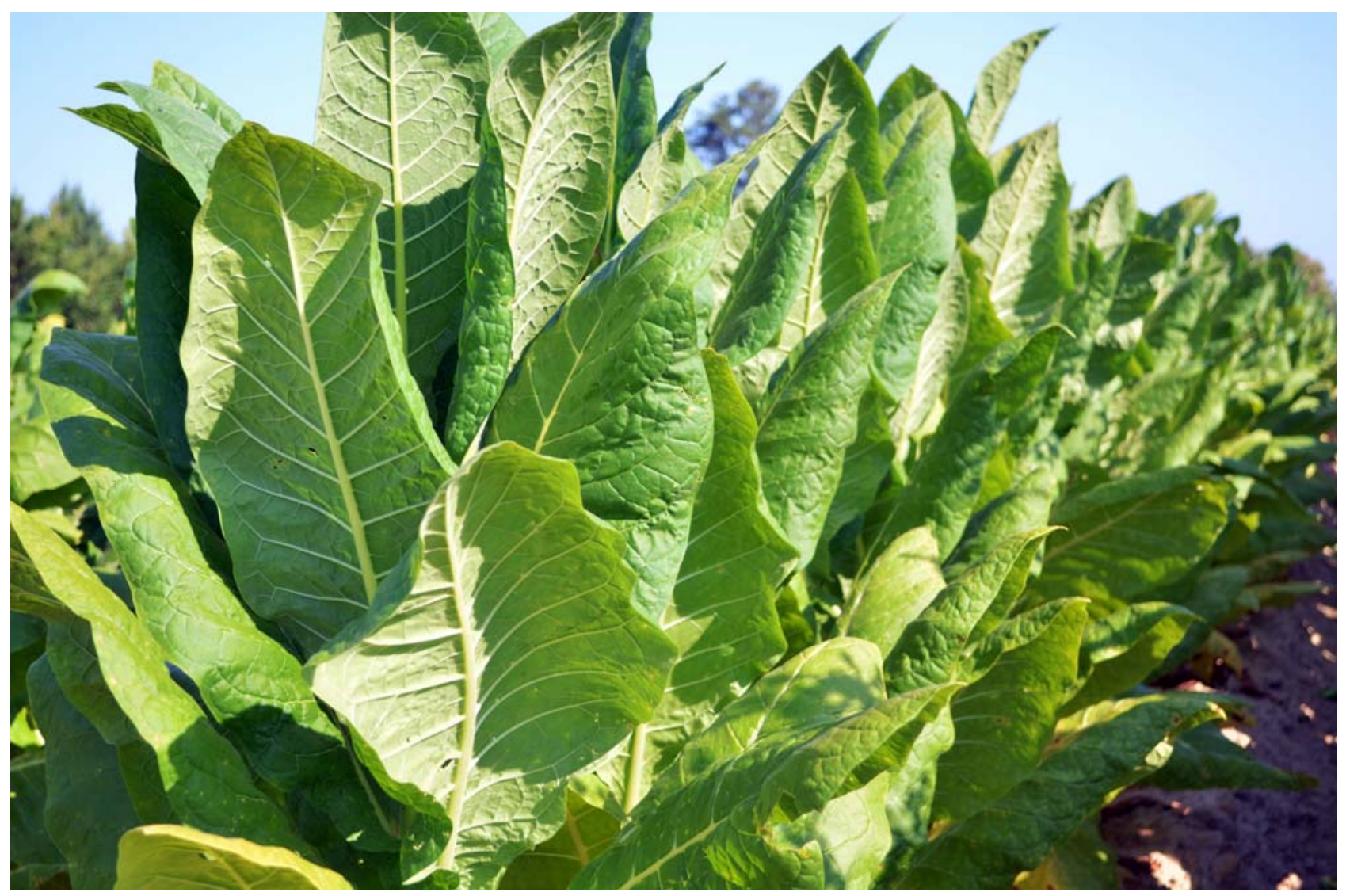

Figure 1. The tobacco plant, Nicotiana tabacum (photograph by Peter Edde).

\section{RESUME}

Le tabac, Nicotiana tabacum, est une culture de grande valeur cultivée dans de nombreux pays tempérés et tropicaux du monde. Plusieurs insectes attaquent le tabac tout au long de la saison, à partir de la production de transplantations, de la croissance sur le terrain, pendant le stockage et dans le produit commercialisé. Cette revue se concentre sur les insectes économiquement importants du semis de tabac ou sur la production de régions productrices de tabac dans le monde. Les espèces couvertes ici sont les pucerons du tabac, le ver gris, la tordeuse du tabac, le sphinx du tabac, la chrysomèle du tabac, le thrips, le scarabée japonais et le taupin du tabac. L'occurrence et l'importance économique de ces insectes d'une région à l'autre est présenté.

Pour chaque insecte discuté, les informations suivantes sont fournies: le nom scientifique et la position taxonomique de l'insecte; sa répartition géographique; le stade qui cause les dégâts et les plantes hôtes; une brève discussion sur la classification et la description de l'espèce; un résumé de la biologie et de l'écologie; et des détails sur la lutte antiparasitaire, notamment les méthodes de dépistage et de surveillance, les seuils d'intervention, les méthodes culturealles (non chimiques), les ennemis naturels et la lutte chimique. En outre, un paragraphe de conclusion est présenté sur la lutte contre les insectes nuisibles au tabac. [Beitr. Tabakforsch. Int. 28 (2018) 117-165]

\section{INTRODUCTION}

Tobacco is a species in the genus Nicotiana, of the plant family Solanaceae, the Nightshade family. The family includes many important vegetable crops such as tomato, potato, pepper, and eggplant. The genus is named after the French diplomat Jean Nicot de Villemain who, in 1560, became the first person to import these plants from the Americas to Europe. There are over 75 naturally occurring Nicotiana species, including 49 and 25 native to America and Australia, respectively (1-3). Most commercial tobaccos cultivated today belong to Nicotiana tabacum L. (1), a plant with a large, stout hairy stem that grows from 1-2 m tall (Figure 1). The National Plant Germplasm System listed over 1,900 N. tabacum cultivated varieties (cultivars) (4).

N. tabacum, henceforth referred to as tobacco, is grown as an annual crop in several countries, primarily in regions with a mild and sunny climate. For best performance of the crop, a frost-free period of 100-130 days from date of transplanting to maturity in the field is needed. The tobacco plant is extremely hardy and adapts to most soil types. However, each tobacco type needs certain soil types and climatic conditions to ensure the desirable qualities (color, texture, and aroma) for which it is prized.

Tobacco is an important economic crop, with high nicotine, cellulose, ammonia, protein, and potassium contents. Major tobacco-producing countries in the world include China, India, Brazil, and the United States. Other countries with significant tobacco production include Indonesia, Turkey, 
Zimbabwe, Zambia, and Malawi. Tobacco is a high-value crop, earning more cash per hectare than most crops (5). For example, one hectare of tobacco in the United States yields about five times the dollar value for corn.

It is necessary to cure tobacco after harvesting and before it can be consumed. Depending on the tobacco type, the leaves are cured with one of the following three methods: 1) air-curing, 2) flue-curing, and 3) fire-curing. To improve aroma, taste, and other quality characteristics, cured tobaccos are held in storage for 1-2 years or more to allow for slow fermentation, or aging of the leaves under natural conditions of temperature and humidity. Cured tobacco leaf is consumed in the form of a cigar, cigarette, dipping tobacco, snuff, or pipe tobacco. The plant can also be used as organic pesticide and, when extracted in the form of nicotine tartrate, it is used in some medicines.

Like many economic crops, tobacco is subjected to damage by several species of insects from the time when the seed is sown in the greenhouse or seed bed in the field, from transplanting to the completion of harvest, in storage, and after the manufactured products have been prepared and offered for sale. The insects that attack the seedling tobacco or the growing crop include hornworms, budworms, flea beetles, aphids, splitworms, green June beetle larvae, Japanese beetles, tobacco budworms, and wireworms.

Other species attacking tobacco, but not mentioned in this review, include webworms, green June beetles, grasshoppers, mole crickets, vegetable weevils, midge larvae, slugs, whiteflies, whitefringed beetles, cabbage loopers, and stink bugs. During storage, the cigarette beetle infests practically all types of tobacco, worldwide. In temperate or subtropical regions, stored tobacco may be attacked by the tobacco moth.

In this review, attention is given to economically important insects that attack tobacco in the greenhouse and in the field. A discussion of the insects that attack the crop in storage will be presented elsewhere. The species covered herein are the tobacco aphids, black cutworms, tobacco budworms, tobacco hornworms, tobacco flea beetles, thrips, Japanese beetles, and tobacco wireworms. However, the occurrence and economic importance of these insects vary from region to region.

For each insect discussed, the following information is provided: scientific name and taxonomic position of the insect; its geographical distribution; the stage of the insect that injures the plant and host plant; a discussion on classification and description of each species; a summary of the biology and ecology; and information on pest management, including scouting/monitoring methods, action threshold, cultural (non-chemical) methods, and natural enemies. A list of some of the registered insecticides used for the control of the pests and, where essential, the recommended application methods were reviewed. However, it should be noted that some insecticides are applied several ways depending upon the pest that is targeted. In addition, the registration of pesticides varies considerable from country to country and each company has a list of insecticides that should not be used on the tobacco leaf that they buy. Finally, a concluding paragraph is presented on the general management of insect pests on tobacco.
TOBACCO APHID — Myzus persicae Sulzer, 1776

Taxonomic position

Order: Hemiptera

Family: Aphididae

\section{Common names}

Cabbage aphid; green sesame aphid; peach aphid; peach curl aphid; peach-potato aphid; potato aphid; tobacco aphid, green peach aphid

\section{Synonyms}

Aphis convolvuli Kaltenbach, 1843

Aphis consors Walker, 1848

Aphis cynoglossi Walker, 1848

Aphis derelicta Walker, 1849

Aphis dianthi Schrank, 1801

Aphis dubia Curtis, 1842

Aphis egressa Walker, 1849

Aphis malvae Mosl, 1841

Aphis persicae Sulzer, 1776

Aphis persola Walker, 1848

Aphis rapae Curtis, 1842

Aphis redundans Walker, 1849

Aphis suffragans Walker, 1848

Aphis vulgaris Kyber, 1815

Myzodes tabaci Mordvilko, 1914

Myzus malvae Oestlund, 1886

Myzus pergandei Sanders, 1901

Myzus persicae nicotianae Blackman, 1987

Myzus persicae var. sanguisorbella Theobald, 1926

Myzus persicae var. cerastii Theobald, 1926

Phorodon cynoglossi Williams, 1891

Phorodon persicae Sulzer, 1776

Rhopalosiphum betae Theobald, 1913

Rhopalosiphum calthae Koch, 1854

Rhopalosiphum lactucellum Theobald, 1915

Rhopalosiphum solani Theobald, 1912

Rhopalosiphum tuberosellae Theobald, 1922

Rhopalosiphum tulipae Thomas, 1879

Siphonophora achyrantes Monell, 1879

Siphonophora nasturtii Koch, 1855

\section{Damaging stages}

Adult and nymph

\section{Distribution}

Myzus persicae is believed to have originated in Asia because its primary host plant Prunus persica L., on which sexual reproduction occurs, is Asiatic. The species is now found everywhere in the world except where there are extremes of temperature or humidity (6). 


\section{Plant hosts}

M. persicae is a key pest of tobacco, worldwide. In addition, the pest has an extensive host range, and damages caused by the species have been reported on many cultivated and wild species in a wide range of plant families, including Amaranthaceae, Amaryllidaceae, Apiaceae, Anacardiaceae, Apocynaceae, Araceae, Asparagaceae, Asphodelaceae, Asteraceae, Balsaminaceae, Boraginaceae, Brassicaceae, Cannabaceae, Caricaceae, Caryophyllaceae, Convolvulaceae, Cucurbitaceae, Euphorbiaceae, Fabaceae, Iridaceae, Lamiaceae, Lauraceae, Liliaceae, Lythraceae, Malvaceae, Myrtaceae, Papaveraceae, Pedaliaceae, Plantaginaceae, Poaceae, Polygonaceae, Rosaceae, and Solanaceae.

However, like many phytophagous insects, this aphid shows different physiological charateristics on its host plants. For example, SEMTNER et al. (7) found that tobacco aphids reared on leaf discs of several weedy species of Solanum had survival, longevity, developmental time, and fecundity like those reared on flue-cured tobacco. Tomato, potato (Solanum tuberosum), Carolina horsenettle (Solanum carolinense), cotton (Gossypium hirsutum) and okra (Abeinoschus ficulneus) were unfavorable hosts. The aphid also performed moderately well on several species of Brassica and Ipomea.

\section{Classification and description}

Aphididae is one of the three families of the superfamily Aphidoidea. The other two members of the superfamily are Adelgidae and Phylloxeridae. Aphididae or aphids differ markedly from Adelgidae and Phylloxeridae in biology and structure. In biology, Adelgidae and Phylloxeridae have retained the ancestral trait of oviparity in all generations, while only the sexed Aphididae females, which are produced in the fall, are normally oviparous. According to BAKER (8), the wing is sligtly different in an Adelgid or Phylloxera from that in some of the specialized genera of the Aphididae. For example, the stigma in the Phylloxeridae is formed by the radial sector, and the stigmal vein is the media. In the Aphididae, on the other hand, the stigma is formed by the radius, and the stigmal vein is the radial sector. In addition, Adelgidae and Phylloxeridae can also be distinguished from the Aphididae by the absence of siphunculi (9). BAKER (8), EASTOP (10), and BLACKMAN and EASTOP (11) have given detailed descriptions of the morphology of aphids. The earliest available record of occurrence of aphids on tobacco in the United States is by HOWARD (12) who reported the potato aphid (Macrosiphum solanifolii (Ashm.)) infesting experimental tobacco in Maryland. Few years later, GILLETTE and TAYLOR (13) reported the occurrence of the green peach aphid $M$. persicae on tobacco in a greenhouse in Colorado. The green color morph of the aphids has been a major problem on tobacco in the United States since at least the mid-1940s (14). During the mid- to late 1980 s, a red or reddish-brown morph with elevated levels of esterases became established and replaced the green as the predominant morph on tobacco in the country (15), and in most tobacco producing regions of the world. BLACKMAN (16) identified both the red and green forms from tobacco as M. persicae nicotia-

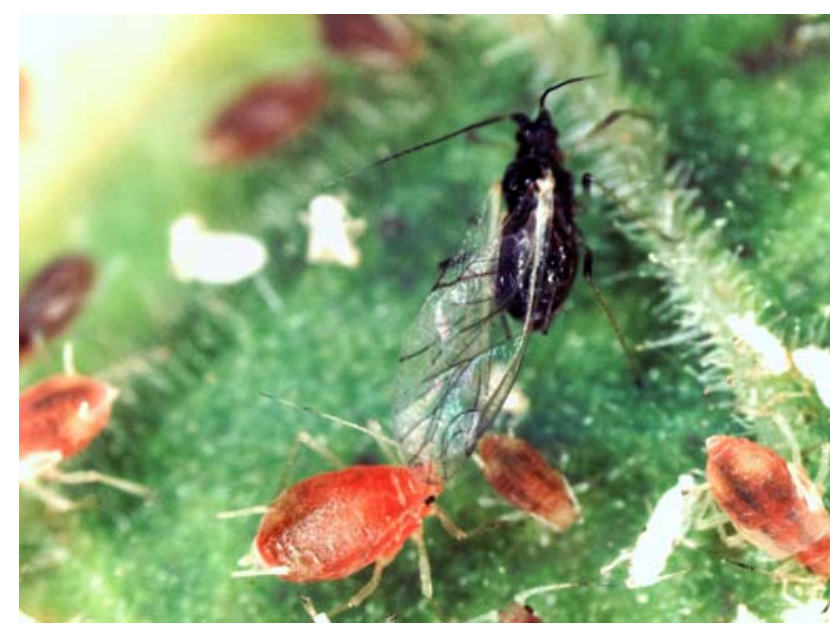

Figure 2. Winged and wingless forms of the tobacco aphid, Myzus persicae nicotianae (photograph by Peter Edde).

nae (Figure 2). The relative preference of $M . p$. nicotianae for tobacco and its ability to thrive on a diet containing high nicotine content have been demonstrated in several studies [e.g., MARGARITOPOUlOS et al. (17); RAMSEY et al. (18)]. For example, RAMSEY et al. (18) showed that the taxon can reproduce on nicotine-containing artificial diets at concentrations that were 15-fold higher than those that were lethal to a non-adapted $M$. persicae lineage. $M$. p.nicotianae and $M$. persicae can be found in either the same country or the same locality (19). As previously indicated, M. persicae nicotianae is the main form of aphids found on tobacco in the United States, and the prevalent aphid on tobacco in the Americas, Africa, Southern Europe, the Middle East, and Asia.

DEVI and SingH (20) have provided a detailed description of $M$. persicae nymphal stages and adult morphs. The species occur as winged (alate) and wingless forms (apterous). The wingless forms are oval-bodied about $1.2-2.5 \mathrm{~mm}$ long and $0.82-1.04 \mathrm{~mm}$ wide. They have welldeveloped lateral frontal tubercles at the base of their antennae, which give the impression of an indentation in front of the head. The antennae are 6-segmented and about 0.6-0.9 times the body length. The cornicles are $0.4-0.5 \mathrm{~mm}$ long, and they are reticulated terminally. The cauda appears triangular, about $0.2-0.3 \mathrm{~mm}$ long and has 6 segments. The siphunculi are cylindrical, twice the length of the cauda, and have a flange. This flange is often absent in nymphal stages. The rostrum is darker at the tip and reaches the hind coxae.

The winged or alate forms are brownish-black, including the head, thorax legs, siphunculi, rostrum and antennae, with a black central patch on the abdominal dorsum from segments 3 to 6 .

Alates tend to be longer (1.78-2.18 mm long) than the apterous adults, but less broad ( $0.85-0.98 \mathrm{~mm}$ wide). Their wings are shiny with brownish veins. Their siphunculi are cylindrical and without a flange, unlike the wingless adults. Wingless $M$. persicae are yellowish green to pale green, and some may have a reddish color.

The tobacco-adapted form (nicotianae) is typically reddish brown and has higher levels of esterases that break down organophosphate and carbamate insecticides than the green 


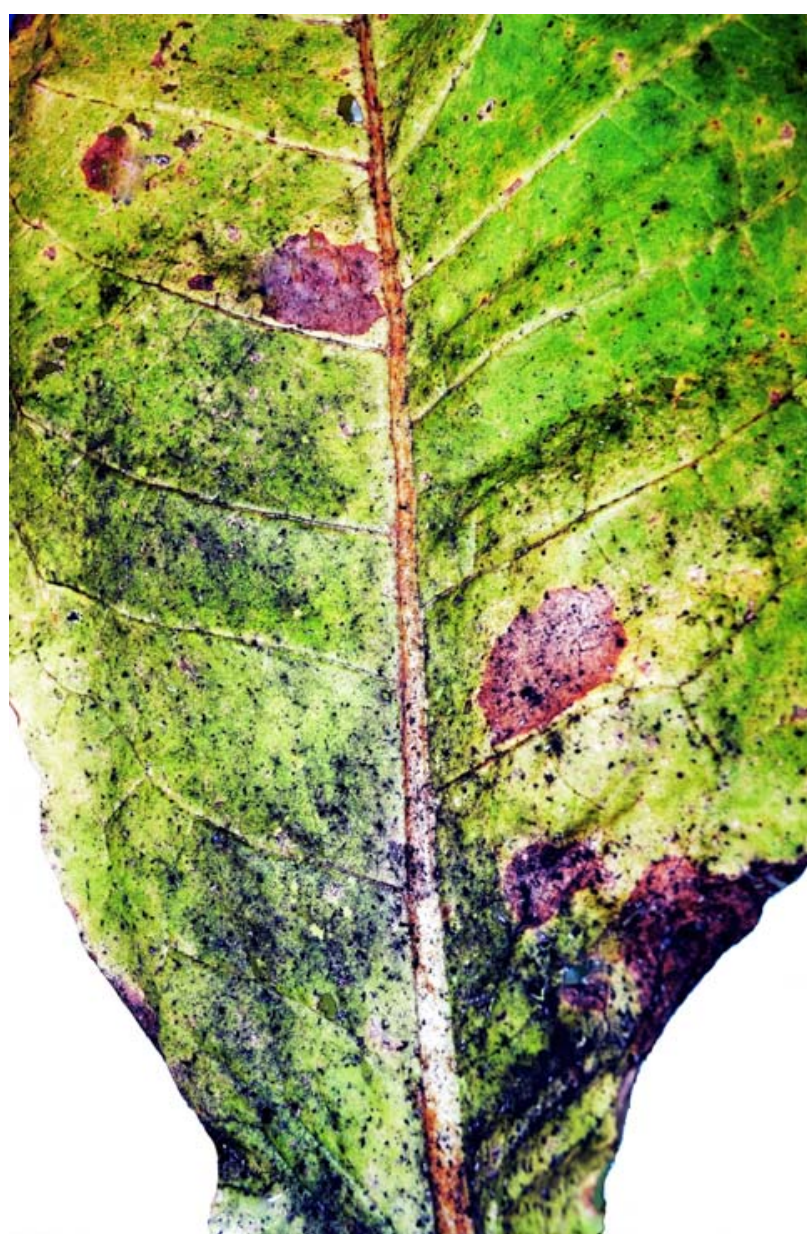

Figure 3. Sooty mold on tobacco leaf due to aphid attack (photograph by Peter Edde).

morph (15). The red morph also has higher fecundity and survival than the green morph at constant temperatures of 25,30 , and $32{ }^{\circ} \mathrm{C}(21)$. In the United States, the red morph of the aphid often makes up higher percentages of the populations in the field as the season progresses and the temperatures and the nicotine content of the tobacco increase (22).

\section{Damage}

Several researchers (e.g., 23-26) have investigated the effects of aphids feeding on yield and quality of flue-cured tobacco. For example, REED and SEMTNER (24) reported that high populations of the tobacco aphid reduced economic returns by 27 and 30\%. Aphids typically occur in colonies on the undersides of the plants' leaves, suckers, and buds. They attack tobacco in both the greenhouse and in the field. Aphids damage the tobacco plant by sucking the sap from growing stems and younger leaves. When aphids are abundant, the plants suffer water stress and become stunted. Leaves from these plants are thin and difficult to cure to the desired yellowish-brown color. A severely damaged leaf may die or may ripen prematurely. Tobacco aphids also contaminate tobacco by depositing cast skins and sugary excretions, known as honeydew, on the leaves. Most aphids secrete honeydew during feeding. Honeydew deposition, though an indirect source of dam- age, may be more serious than the actual feeding because it causes the leaves to stick together making them difficult to separate without damage and makes the leaves susceptible to sun scald. Under high humidity, a sooty mold grows on the honeydew giving the leaves a blackish appearance (Figure 3), which makes them less desirable for curing and reduces their quality.

The economic impact of $M$. persicae also derives from its ability to vector viruses. For example, the aphid is an important vector of various viral diseases of tobacco, such as tobacco etch virus (tobacco etch), tobacco vein distorting virus, tobacco vein-mottling virus, tobacco yellow net virus, and the bushy-top virus of tobacco in parts of Asia and Africa. According to CABI (6), M. persicae is also known to transmit the following viruses: alfalfa mosaic virus, bean common mosaic necrosis virus, bean common mosaic virus (common mosaic of beans), bean leafroll virus (pea leafroll virus), bean yellow mosaic virus (bean yellow mosaic), beet mild yellowing virus (beet mild yellowing), beet mosaic virus (spinach mosaic virus), beet western yellows virus (turnip (mild) yellows), beet yellows virus (beet yellows), carnation latent virus, cauliflower mosaic virus (cauliflower mosaic), clover yellow vein virus (CYVV), cowpea aphid-borne mosaic virus, cucumber mosaic virus (cucumber mosaic), East Asian passiflora virus, hop mosaic virus, lettuce mosaic virus (lettuce mosaic), maize dwarf mosaic virus (dwarf mosaic of maize), onion yellow dwarf virus (onion yellow dwarf), papaya ringspot virus, pea enation mosaic virus-1 (pea virus 1), peanut mottle virus (peanut mottle), peanut stripe virus (groundnut stripe disease), peanut stunt virus (peanut stunt), pepper veinal mottle virus, plum pox virus (sharka), potato leafroll virus, potato virus Y (potato mottle), red clover vein mosaic virus, soybean mosaic virus (soybean mosaic), sugarcane mosaic virus (mosaic of abaca), tulip breaking virus, turnip mosaic virus (cabbage A virus mosaic), watermelon mosaic virus (watermelon mosaic), and zucchini yellow mosaic virus.

\section{Biology and ecology}

The life cycle of $M$. persicae varies depending on environmental conditions. Based on host use and form of reproduction, the life cycle of the aphid can be described as heteroecious holocyclic, especially in the more temperate areas, where the insect alternates between primary and secondary host plants and can reproduce sexually and asexually. In colder regions, a generation of males and egg-laying females develops in the fall. The aphid overwinters in the egg stage. The eggs are laid mostly on Prunus spp., and wild Plumeria. M. persicae eggs are green when newly deposited but soon turn shiny black. Hatching occurs in the spring, and the nymphs feed on flowers, young foliage, and stems of the primary host. The second or third spring generations of the aphids develop wings and leave from overwintering hosts to infest tobacco fields. The insect continues to reproduce asexually on the secondary host until environmental conditions become unfavorable, and winged adults return to Prunus spp. in the fall where mating occurs, and eggs are deposited and overwinter. However, M. persicae does not reproduce sexually in the southern United States, as far north as Tennessee and 
Maryland, where most of the country's tobacco production occurs because males are not present, and no sexual reproduction is known to occur in $M$. p. nicotianae (16). The host plants in the fall, winter, and early spring include cabbage, collard greens, raddish, turnip, and wild mustards. Population build-up occurs when viviparous parthenogenetic winged females fly into tobacco fields, usually during the middle part of the growing season. They settle on the plant, feed, and give birth to young nymphs. They molt four times before developing into wingless females, which in turn produce another generation of wingless females. Newborns can reach adulthood and begin to reproduce in about a week. Successive generations of wingless females are produced throughout the tobacco-growing season. However, winged females are produced at intervals; they serve primarily as a means of transfer to progressively younger crops.

Several environmental factors that influence the production of winged aphids include light, temperature, crowding, starvation, wilting of the host plant, and parentage, etc. The life span of the aphid ranges from 1 to 3 weeks, and a female can produce up to 80 offspring. There could be from 15 to 21 generations of wingless aphids in one year until available host plants or environmental conditions become unfavorable. The best temperature for aphids is about $22{ }^{\circ} \mathrm{C}$, with most activity occurring during the warmer months. The lower and upper temperature thresholds for aphid development are about $5^{\circ} \mathrm{C}$ and $35^{\circ} \mathrm{C}$, respectively. As noted above, REED and SEMTNER (21) reported that the red morph produces more nymphs and lives longer than the green morph at constant temperatures of 25 and $30{ }^{\circ} \mathrm{C}$. Longevity and fecundity are similar at temperatures of $20^{\circ} \mathrm{C}$ and less.

\section{Management}

\section{- Scouting technique}

Aphids occur on tobacco plants at about 3-4 weeks after transplanting. They colonize on the upper stalk and developing leaves, feeding on the underside of the leaves. Tobacco fields should be scouted at least once a week through to topping, i.e., the removal of the plant flowers. Carefully examine the undersides of leaves in the upper one-third of the plant for aphids and the upper surfaces of the middle and lower leaves for honeydew.

Scientists at North Carolina State University suggest using a sampling scheme based on field size (27). Briefly, in fields of less than $1.2 \mathrm{ha}$, walk through the entire field in a "zigzag" or "W" sampling pattern, make eight stops and examine at least five plants for a total of 40 plants across the field. For fields 1.6-3.2 ha, make at least ten stops and examine five plants at each stop for a total of 50 plants. In larger fields, for each 1.6 ha a field exceeds 3.2 ha, add two stops (observing five plants at each stop). For example, in a 16.2 ha field; add eight stops for a total of 26 stops with 130 plants examined across the field. Sampling accuracy improves with the more stops made. Do not sample the same plants each week.

\section{- Action threshold}

The economic threshold recommendations for aphids vary with countries. In Canada and major tobacco growing regions of the United States, the recommendation is to treat the field when $10 \%$ of the plants have 50 or more aphids before "topping". Topped tobacco plants have thicker leaves and higher alkaloid content than plants that were not topped, and they are less susceptible to aphid attack. Chemical control for aphids is often not needed posttopping.

\section{- Non-chemical}

Tobacco varieties with resistance to aphids and which also produce leaves with desirable qualities have not been developed. Consequently, pest management strategies in tobacco plants often rely on the use of insecticides. However, as shown in the following examples, several wellestablished agronomic practices may help to lower populations of aphids in tobacco fields:

- In the United States, tobacco aphids primarily come into the crop in mid-June or earlier and early July in response to the phenology of their spring host plants. To minimize infestations and proliferation of aphids and viral diseases, growers are encouraged to transplant tobacco early to avoid severe aphid damage.

- Only tobacco free of aphids should be transplanted.

- Stalks should be destroyed as soon as possible after harvest is completed.

- Good weed-management should be practiced within tobacco fields and surrounding areas.

- Farming practices such as crop rotation, no-till, etc. may help to reduce aphid populations by making the environment less favorable for the pest.

- Aphid populations usually crash following topping; therefore, timely topping operations and the application of sucker control chemicals after topping can be used to reduce aphid populations and damage.

\section{- Natural enemies}

For a more detailed list of aphid natural enemies, consult relevant work on the subject, including that by STARÝ (28), MINKS et al. (29), and BODENHEIMER and SWIRSKI (30). JosHI et al. (31) gave a detailed literature review on the biological control of aphids in India. AsLAN et al. (32) and ASLAN and UYGUN (33) gave a list of aphid parasitoids in Kahramanmaras, Turkey.

The most important natural enemies of aphids include following insects: 1) lady beetles (Coleoptera: Coccinellidae), 2) syrphid fly larvae (Diptera: Syrphidae), 3) stilt bugs (Hemiptera: Berytidae), 4) lacewings larvae (Neuroptera: Chrysopidae), and 5) aphidiine parasitoids (Hymenoptera: Braconidae). The lady beetles appear to be the most common on tobacco in North America and appear to play the most key role in aphid population control (34). Some of these insects, e.g., lacewings, convergent ladybird beetle (Hippodamia convergens) and the two-spotted lady beetle, Adalia bipunctata, are commercially available from many biological control suppliers in the United States, and elsewhere. 
In addition to insects, fungal diseases particularly those caused by Entomophthorales, e.g., Erynia spp. and Pandora spp. are important natural factors for reducing aphid populations in many cropping systems, including tobacco $(35,36)$. Working in Virginia, USA, REED and SEMTNER (34) reported that $P$. neoaphids often control aphids from July through September, especially in wet seasons. However, epizootic disease often occurs too late to keep aphid populations from reaching damaging levels, and infected aphids often remain attached to leaves, causing serious leaf contamination (37).

Members of the virus family Dicistroviridae can cause severe pathogenic effects in arthropods (38). For example, two dicistroviruses are known to infect aphids: aphid lethal paralysis virus (ALPV) and Rhopalosiphum padi virus (RhPV) (39). An isolate of ALPV, ALPV-AN (GenBank accession number JX480861.1) was shown to be highly pathogenic to the green peach aphid, Myzus persicae, in laboratory experiments $(38,40)$.

Although JOSHI et al. (31) noted that parasitoids in general, and especially aphidiine parasitoids, have greater potential than predators and entomopathogens to controlling aphids both in the fields and in glasshouses, Aphelinidae parasitoids, however, are not very important for aphid control on tobacco in the United States and are only on field tobacco early in the season and in the greenhouse. Although natural enemies are usually abundant in tobacco field, they are effective only when the populations of the pest are low or moderate but have difficulties keeping large populations of the pest below economic injury levels.

Other beneficial organisms that have been reported to attack aphids in tobacco and related ecosystems include the following:

- Araneae - Alopecosa pulverulenta (Lycosidae), Phylloneta impressa (Theridiidae), and Xysticus sp. (Thomisidae).

- Bacteria - Bacillus subtilis, B. thuringiensis (Bacillaceae), and Pseudomonas fluorescens (Pseudomonadaceae).

- Coleoptera - Agonum dorsale, Poecilus cupreus, Pterostichus melanarius (Carabidae), and Dicranolaius bellulus (Melyridae).

- Dermaptera - Doru luteipes, Forficula decipiens (Forficulidae)

- Diptera - Aphidoletes aphidimyza, Endaphis aphidimyza (Cecidomyiidae).

- Fungi-Conidiobolus spp. (Ancylistaceae), Beauveria bassiana, Lecanicillium spp., Nomuraea rileyi, Metarhizium spp. (Clavicipitaceae), Fusarium pallidoroseum (Nectriaceae), Neozygites fresenii (Neozygitaceae), Purpureocillium lilacinum (Ophiocordycipitaceae), Verticillium lamellicola (Plectosphaerellaceae), Paecilomyces spp. (Eurotiales), and Glomerella cingulata (Glomerellales).

- Hemiptera - Anthocoris spp., Orius spp. (Anthocoridae), Jalysus wickhami (Berytidae), Geocoris spp. (Geocoridae) Deraeocoris spp., Dicyphus spp., Macrolophus spp., Nesidiocoris tenuis (Miridae), Nabis spp. (Nabidae), Podisus spp. (Pentatomidae), and Zelus renardii (Reduviidae).

- Hymenoptera - Aphelinus spp. (Aphelinidae), Aphidius spp., Binodoxys spp., Cotesia rubecula,
Diaeretiella rapae, Ephedrus spp., Lipolexis spp., Monoctonus nervosus, Neoephedrus kalimpongensis, Ovomermis spp., Praon spp., Toxares spp., Trioxys spp., Zele chlorophthalma (Braconidae), and Solenopsis invicta (Formicidae).

- Neuroptera - Hemerobius pacificus, Micromus spp., and Wesmaelius subnebulosus (Hemerobiidae).

\section{- Chemical}

Insecticides recommended for aphid control have included carbamates (methomyl), neonicotinoids (acetamiprid, imidacloprid, thiamethoxam), organophosphate (acephate), pyrethroids/pyrethrins (bifenthrin, cyhalothrin, cyfluthrin, cypermethrin + chlorpyrifos, deltamethrin), pyridine (flonicamid), and selective homopteran feeding blockers such as pymetrozine. Azadirachtin derived from the natural oil found in seeds of the neem tree can be also applied to control aphids and other soft-bodied insects. In addition, horticultural oil (summer oils) and fatty acid salts (insecticidal soaps) are very effective against many aphids and related insects.

Insecticides are currently the most reliable means of reducing high tobacco aphid populations below damaging levels. Aphicides, that is, pesticide intended to kill aphids, can be grouped into two major groups: 1) those that are applied as foliar sprays in response to aphid infestations, such as pyrethroids/pyrethrins, and 2) systemic insecticides applied to soils before transplanting as a preventative treatment, such as acephate and imidacloprid. Systemic insecticides give long term protection against aphid population buildup during the early stages of plant growth when the plant is most susceptible to aphid attack. Some aphicides (e.g., acetamiprid), however, can be applied as a foliar spray or a soil treatment against a wide spectrum of aphid species. For best results, foliar insecticides should be applied before aphid populations become too high. Thorough coverage including the underside of the leaves improves control with foliar insecticides. According to REED AND SEMTNER (34), the use of higher pressure higher spray volume (75.7 liter/acre or more), higher pressure (4.14 bar or more), and a sprinkler-sticker can improve coverage.

M. persicae shows many characteristics that contribute to its persistence and pest status on agronomic crops. For example, chemical management of aphids has been difficult and unpredictable because of the ease with which the insects develop resistance to pesticides within both local and widespread geographic regions. The first report of insecticide resistance in $M$. persicae in the United States was by ANTHON (41). The resistance was to an organophosphorus insecticide. However, insecticide resistance is now reported to most classes of insecticide, including the organophosphates, carbamates, pyrethroids, cyclodienes, and neonicotinoids. According to SiLvA et al. (42), M. persicae has developed resistance to at least 70 active ingredients, one of the highest amongst all arthropods. At least six genetically independent mechanisms of resistance have been reported in this species worldwide. The mechanisms, according to SILVA et al. (42) include: (i) Modified acetylcholinesterase, which confers resistance to organophosphates and carbamate insecticides, (ii) $k d r$ and super $k d r$ 
mutations in a voltage-gated sodium channel, which is the target of pyrethroids and organochlorines, (iii) the mutation of the GABA receptor, $r d l$, which is target of organochlorines of the cyclodiene type, (iv) mutation of a key residue in the loop D region of a $\mathrm{nAChR}$ b1 subunit, (v) the over-production of esterases E4 or FE4, which confers resistance to organophosphates, pyrethroids and to a lesser extent carbamates, and (vi) over-production of a cytochrome P450 confers resistance to neonicotinoids. Another factor that has contributed to $M$. persicae persistence as pest is its short development times. This factor particularly contributes high intrinsic rate of increase which result in overlapping generations and allow the pest populations to reach economic injury levels quickly. In addition, aphid populations tend to resurge following applications of certain insecticides for other insect pests due to the killing or repelling of beneficial insects.

The varied insecticide resistance mechanisms described above for $M$. persicae illustrate the complexity of the involved evolutionary responses. An insecticide resistance management strategy is recommended that emphasizes the rotation of insecticides that offers no cross-resistance along with the use of other tactics of integrated pest management.

BLACK CUTWORM - Agrotis ipsilon Hufnagel, 1766

\section{Taxonomic position}

Order: Lepidoptera

Family: Noctuidae

\section{Common names}

Black cutworm; dark sword grass moth; gram cutworm; greasy cutworm; lance rustic; overflow worm; potato cutworm; silver Y-moth; tobacco cutworm; and ypsilon dart

\section{Synonyms}

Agrotis aneituna Walker, 1865

Agrotis aureolum Schaus, 1898

Agrotis bipars Walker, 1857

Agrotis frivola Wallengren, 1860

Agrotis pepoli Bertolini, 1874

Agrotis telifera Harris, 1841

Agrotis ypsilon Rottemburg, 1776

Bombyx idonea Cramer, 1780

Bombyx spinula Esper, 1786

Noctua suffusa Denis \& Schiffermüller, 1775

Noctua ypsilon Rottemburg, 1777

Phalaena idonea Cramer, 1780

Phalaena ipsilon Hufnagel, 1766

Phalaena spinifera Villers, 1789

Phalaena spinula Donovan, 1801

Damaging stages

Larva

\section{Distribution}

Agrotis ipsilon is prevalent in almost all agricultural areas of the world, being found throughout the United States, in southern Canada, Mexico, South America, Europe, Africa, Asia, East Indies, New Zealand, and Australia (43, 44). It is one of the most widely distributed of the cutworms.

\section{Plant hosts}

A. ipsilon is a highly polyphagous insect. It attacks the seedling or vegetative growing stage of several economically important crops in many plant families including Amaranthaceae, Apiaceae, Asparagaceae, Asteraceae, Brassicaceae, Caryophyllaceae, Chenopodiaceae, Convolvulaceae, Cucurbitaceae, Ericaceae, Euphorbiaceae, Fabaceae, Ginkgoaceae, Iridaceae, Lamiaceae, Malvaceae, Musaceae, Papaveraceae, Pedaliaceae, Poaceae, Rosaceae, Rubiaceae, Rutaceae, Solanaceae, Theaceae, Vitaceae, and Zingiberaceae.

Periodically, black cutworms have been severe pests of tobacco grown in southern Africa, North America, Malaysia, India, and other regions (45). The black cutworm is also one of the most destructive insects on corn seedlings in the United States, China, and New South Wales $(46,47)$, and of cotton seedlings, sugar beets, flax, legumes, vegetables, and golf course greens in Japan and the United States (48-50). In South America, the black cutworm has commonly been found attacking young coffee (Coffea arabica) plants in Brazil (51) and cotton in several regions in Peru (52).

\section{Classification and description}

The black cutworm, A. ipsilon, is a moth in the family Noctuidae. Noctuids (Latin "night owl") are nocturnal in habit, though some are diurnal. KIRTI and DAR (53) provided keys for the identification of noctuid subfamilies. Most noctuids are usually dull gray to brown in color and have lines or spots on their wings. Wingspans range from 20 to $48 \mathrm{~mm}$, depending on the species. Frenulum and ocelli are often present. The labial palpi are of moderate dimensions, upturned, with the second segment densely scaled, and the third generally short. The hind tibia always bears two pairs of spurs. Similar to some members of the super family Noctuoidea, the ventral forewing of noctuid moths has quadrifid forewing venation. Metathoracic tympanum is present and orient toward the anterior end of the body. When at rest, most noctuid moths hold their wings above their bodies like a roof. Abdomens never have contrasting bright red or orange colors.

Noctuids can also be readily separated from other Lepidopterans based on venation of the hind wing, where $\mathrm{SC}+\mathrm{R} 1$ is separated from RS and is connected with the discal cell at the base. Another identifying feature is the number of tibial spurs, i.e., 0-2-4 [foreleg-midleg-hindleg], and the foreleg usually bears an epiphysis, a leaf-like or spur-like process. The male antennae are strongly pectinate, bipectinate or serrate, offering characters that separate groups of species within a genus.

HAMPSON (54) gave the following description of the genus Agrotis: eyes naked and without lashes; proboscis fully formed; palpi obliquely porrect, the 2 nd joint evenly scaled, 


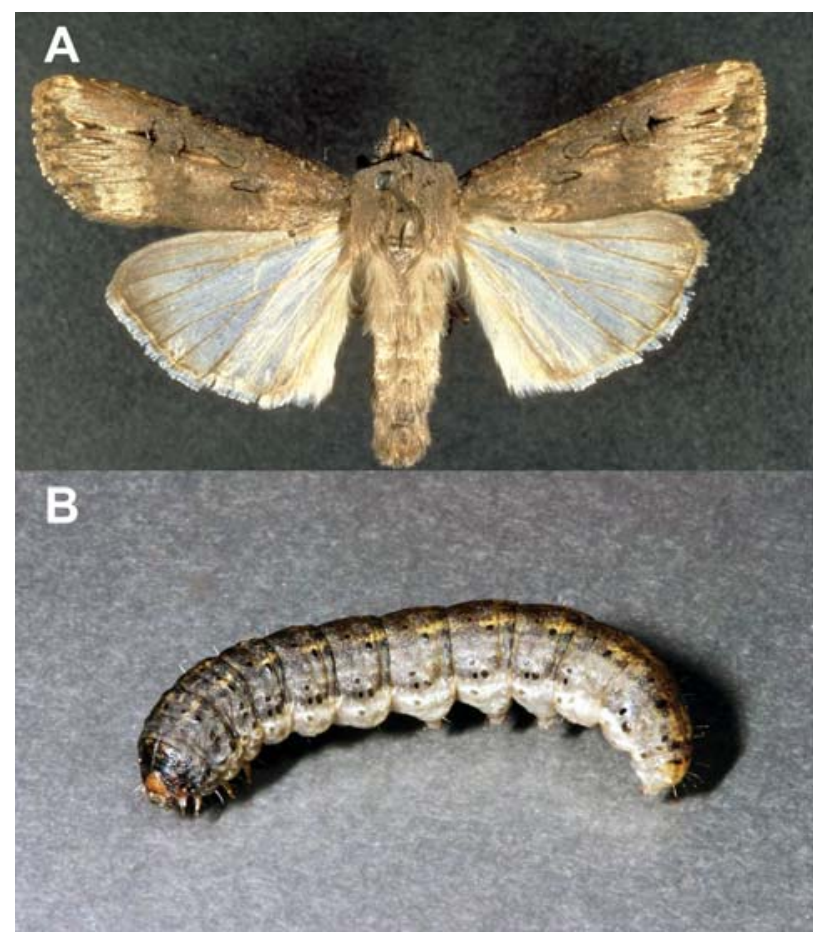

Figure 4. (A) Black cutworm moth, Agrotis ipsilon (photograph by W.M. Hantsbarger, https://Bugwood.org, with permission) and (B) black cutworm, Agrotis ipsilon (photograph courtesy of Kansas State University, Department of Entomology).

the 3rd prominent. Thorax and abdomen without tufts, the latter a bit flattened. Tibiae are very strongly spined. The outer margin of the forewings is not crenulate; hindwing with veins 3 and 4 from cell. There are many distinct species of cutworms contained in the genera Agrotis. The adult or moth of $A$. ipsilon (Figure 4) can be recognized by its long, narrow wings, which, when spread, measure about 36-55 $\mathrm{mm}$ across. The inner two-thirds of the forewings are uniformly mahogany brown, while the outer one-third (distal area) is much lighter in color. The reniform is kidney shaped, relatively large, and dark colored. The middle of the reniform is marked outwardly by a distinct black dagger-shaped dash, which typically stops before reaching the subterminal line. Two other dashes of similar shape are directed toward this dash from the subterminal line. The orbicular spot is moderate or small, uniformly colored, variable in shape, narrowly outlined in black. Claviform is small and outlined in black. The transverse posterior line is dark and irregular. The subterminal line is close to outer margin, with prominent tooth-like projections, which are marked by preceding arrow-shaped points that are obvious and black opposite the cell. The projections are longest on veins three and four. The hind wings are whitish or dusky, with a pearly lustre, and a brown tint along the margins. The antennae of males are evenly bipectinate, and the anterior tibiae are sparsely spined. Female antennae are filiform.

\section{Damage}

The larval stages of $A$. ipsilon are primarily pests of seedling plants and are very damaging up to 4 weeks after transplanting into the field. The main damage caused by black cutworms is that they cut off tobacco transplants. This causes a need for replanting or running the risk of producing a crop with missing plants, which affects crop uniformity. This increases labor costs and diminishes crop quality. A. ipsilon belongs to a group of species of cutworms known as the "tunnel-making cutworm" or "tunnel makers" (55). Other members of the group include the swordman dart or claybacked cutworm, A. gladiaria (Morrison); rascal dart or palesided cutworm, A. malefida (Guenee); and dusky cutworm, A. venerabilis (Walker). Tunnel-making cutworms have the habit of making tunnels in the moist soil near their host plants, where they hide during the day. At night, they appear and cut off portions of the host plants, which topples them, and sometimes they drag this food into their tunnels to continue their feeding. However, some plants, such as cabbages are often bored into from below, and the larvae can be found in the borehole. However, young larvae of these species will feed above ground on weeds or young seedlings, leaving small irregular holes in the leaves. The quantities of food consumed in the first three instars are small, and have negligible impact on the plant until about the fourth instar, when feeding increases abruptly $(56,57)$. Cutworms often appear first along weedy margins or portions of the bed lying along field edges. WILLIAMSON and POTIER (58) reported that the greatest feeding activity of the larvae occurs between midnight and one hour before sunrise.

\section{Biology and ecology}

Detailed life history and habits of the more common cutworms in North America, including the black cutworm, has been published $(43,55,59)$. MAXWELL-LEFROY and GHOSH (60) provided a detailed description of the biology of $A$. ipsilon under field conditions in India. CRUMB (43) presented good descriptions of the life stages, and presented a key for use in the identification of eggs, larvae, and pupae of important cutworm species in the United States. Methods for the continuous rearing of $A$. ipsilon under laboratory conditions using artificial media was described by MANGAT (61), REESE et al. (62), and ALLAN (63). Information on the seasonal distribution and migratory habits of $A$. ipsilon in North America was provided by SHOWERS et al. $(64,65)$, in Europe by BRETHERTON (66), in India by MAXWELLLEFROY and GHOSH (60), and in Israel and the Middle East by ODIYO (67) and RIVNAY and YATHOM (68).

In some parts of the world, the black cutworm appears throughout the year either with continuous generations or a diapausing stage. However, the nature of the diapausing stage has yet to be fully understood (69). In the United States along the Gulf Coast and in Mexico, it is believed that $A$. ipsilon overwinters as pupa or adult within the pupal shell. However, the larvae are found from early fall to late spring during mild winters in Florida, USA, suggesting that the insects likely pass the winter as either larvae or pupae in subtropical environments (70). Moths of the first or overwintering brood emerge from about the middle of March to early May $(43,56)$. In northern latitudes, such as Kansas, USA (71) and Illinois (72), A. ipsilon does not overwinter, and infestation by the insect during the spring is the result of migration of adult moths from overwintering 
areas in the south $(64,65)$. As the weather conditions become hot and dry, the moths migrate northward by mass movement on the leading edges of cold fronts to areas of favorable weather conditions (64). ODIYO (67) observed similar migratory behavior by the species in the Middle East; he reported an annual mass migration of $A$. ipsilon from Egypt to Israel in spring, in order to avoid the very hot Egyptian summer.

The male moth uses female-produced sex pheromones to find its mating partner. HiLl et al. (73) identified two compounds: (Z)-7-dodecen-1-yl acetate (I) and (Z)-9-tetradecen-1-yl acetate (II) as the sex pheromone components of A. ipsilon. Female moths emit the compounds in an approximately 5:1 ratio. Male moths have two different receptor sites for the two compounds. SwIER et al. $(74,75)$ studied mating behavior and found that 4-day-old females were most attractive and mating generally occurred 4 days after female emergence. Most mating activity occurs after dark between 2400 and 0300 (CST).

ALLAN (63) observed a preoviposition period of about 4-6 days after emergence, at $18-26{ }^{\circ} \mathrm{C}$ and $30-80 \%$ relative humidity. However, SWIER et al. $(74,75)$ noted that oviposition began 3 days after mating and peaked at 6 days under laboratory conditions of $24-25{ }^{\circ} \mathrm{C}$ and $70-75 \%$ relative humidity. Reproductive ability of the black cutworm is high. WALKDEN (55) found that the number of eggs in dissected field-collected females ranged from 477 to 2,257, with an average of 1,367 eggs. ABDEL-GAWAAD and EL-SHAZLI (76) reported females as laying from 386 to 754 eggs at $22{ }^{\circ} \mathrm{C}$ and $65-70 \%$ relative humidity. Other reports suggest the moth can lay up to 3,000 eggs per female (67). The percentage of egg hatching is also very high, reaching up to $90.8 \%$ (76).

The eggs of $A$. ipsilon are white when newly laid, but they turn brown or pale red with development. They are almost spherical in shape, with a slightly flattened base. They measure $0.6-0.7 \mathrm{~mm}$ in diameter and $0.43-0.50 \mathrm{~mm}$ high $(43,55)$. The eggs bear $35-40$ slightly curved ribs. The ribs are alternately long and short, and they radiate from the apex. Under field conditions, the eggs are deposited in batches of 1-30 on leaves and stems that are near the ground (43). With few exceptions, egg-laying occurs during the night. Eggs are not laid on bare soil. They are deposited in low-growing broadleaf plants that grow in damp, low areas within fields, overflow ground, and in other areas overgrown with weeds, especially winter annual weeds (71). The duration of the egg stage is $3-5$ days at $18-26^{\circ} \mathrm{C}$ and $30-80 \%$ relative humidity (63). This observation is similar to findings by ABDEL-GAWAAD and EL-SHAZLI (76).

There are reports of five $(55)$ to eight $(55,56)$ larval instars, but six or seven appear to be the most common $(43,55,76$, 77 ). The larval stage (Figure 4 ) is about 20-28 days at $18-26{ }^{\circ} \mathrm{C}$ with relative humidity fluctuating between $30-80 \%$ (63). The average duration of the larval stages under normal summer conditions in the United States is about $2-3,1-2,1-2,2-4,2-4,2-15$, and 4-15 days for instars one through seven, respectively (55). Optimal relative humidity for larval development lies between $75 \%$ and $80 \%$. Mean and range head capsule widths are about $0.29(0.26-0.35), 0.44(0.36-0.52), 0.79(0.61-0.1 .11), 1.39$ (0.77-2.07), 2.14 (1.09-2.8), 3.06 (1.47-3.94), and 3.6
(3.14-3.95) $\mathrm{mm}$ for instars one through seven, respectively (56). The head capsule is the least variable major part of the black cutworm larvae, making it a good guide for figuring out the instar in the species. SATTERTHWAIT (56) found that the head measurement is 1.5 times the size of the preceding head width if the growth is completed in six instars. Larval body length was reported to be 3.5, 5.3-6.2, 7, 10, 20-30, 30-45 mm for instars one through six, respectively (43). Larval body lengths are similar for instars six and seven, which is about $50 \mathrm{~mm}$.

MAXWELL-LEFROY and GHOSH (60) studied the behavior of the black cutworm larva. The newly hatched larvae curled up and fell to the ground when the plant upon which they rested was disturbed. The larvae then continued to feed on dead leaves and other debris on the ground, as they would not climb back up the plant. As they matured, they moved to cracks and holes in the ground and fed upon plants, mostly at night, by cutting stems at or just above the ground level. Larvae tend to be cannibalistic, and significant mortality can be seen in large overcrowded populations.

When fully grown, the larvae are about 30-45 mm long (43). The head is distinctly reticulate, with adfrontal sutures ending in the occipital foramen. Under magnification, the skin granules appear coarse, strongly convex, or conical, interspersed irregularly with smaller secondary granules. When viewed from the top, the general body color is uniformly dark greasy-gray to black, while it is greenishyellow from below. A pale yellow line runs along the center of the back, and three others of the same color run along the side of the body, the upper of which on each side is the most distinct. Black cutworms are best identified by the differences in size of the black and shiny tubercles found along the middle of the back. On each abdominal segment, the pair of tubercles closest to the head (tubercle I) is about one-third the size of the pair nearest to the abdomen (tubercle II) $(43,55)$.

The matured larva makes puparium about $3-12 \mathrm{~cm}$ within the soil in which pupa is produced. Pupa is deep brown, about $17-22 \mathrm{~mm}$ long and 5-6 $\mathrm{mm}$ in diameter. ABDELGAWAAD and EL-SHAZLI (76) estimated that the pupa stage lasts about $21.3 \pm 0.8$ days at $22 \pm 1{ }^{\circ} \mathrm{C}$ and $65-70 \%$ relative humidity, which was longer than the observations by Allan (63) who reported 10-12 days at $18-26^{\circ} \mathrm{C}$ and $30-80 \%$ relative humidity. Under field conditions in northern Tennessee, USA, the pupal stage lasts for about 2 weeks or more during July-August, while the AugustSeptember pupal stage needs about 3 weeks for the earlier individuals, and 8 or 9 weeks for the later ones (43). CRUMB (43) further noted that the first week of October is about the earliest date of pupation that results in overwintering pupae; pupae that are formed before this date became moths in the same season. As would be expected, development of the black cutworm is governed by temperature. The life cycle from egg to adult at the three constant temperatures was estimated to be about 67,41 , and 32 days at 20,26 , and $30^{\circ} \mathrm{C}$, respectively.

A. ipsilon has several generations annually, the number of generations being dependent on location. The insect is capable of five generations per annum in South Africa (78). In North America, two generations of the insect are possible annually in Canada, while up to four or more are common in the United States, where, for example, COOK 
(79) found that the insect has two generations in Minnesota, SATTERTHWAIT (56) found three generations in Missouri, while CRUMB $(43,80)$ observed four generations a year in northern Tennessee. During autumn, A. ipsilon respond to the deteriorating environmental conditions by using certain weather systems with northerly (southward displacement) near-surface airflow to complete midcontinent migration to their more favorable areas and overwintering sites in the gulf coast region (65).

\section{Management}

\section{- Scouting technique}

Cutworm adults can be monitored using pheromone traps. Pheromone trapping helps in early detection of pest occurrence and timing of larval monitoring to improve pest management decisions. Pheromone traps should be set up between March and April. However, this date may vary slightly depending on the region, and the location within the region. The number of moths captured per night in pheromone traps should be recorded to pinpoint when significant capture of the moth occurs. Intensive scouting for larvae should start 2 weeks after the first significant capture of moths in traps.

Cutworms damage tobacco during the first 4-5 weeks after transplanting. The Canadian Tobacco Research Foundation recommends scouting for cutworms every week, from transplanting through to early July. Select and stop at 5-10 sites or more and examine 20 plants per site for signs of cutworm feeding (holes in leaves, missing growing points, or stems severed at soil line) (81). It is recommended that the plants to be sampled should be pre-selected at random before starting scouting to avoid biasing counts by selectively stopping at damaged plants.

\section{- Action threshold}

Treatment is recommended when at least $5 \%$ of the plants show signs of cutworm feeding, or when two or more cutworms are found per 100 plants (81).

\section{- Non-chemical}

The following is a brief outline of the non-chemical methods recommended for management of cutworms:

- Use good agronomic practices that promote crop pest suppression, such as keeping weeds down always. Crop fields free from weeds typically suffer far less from cutworms than weedy ones.

- Plowing the land before using it as a tobacco plant bed or tobacco field may reduce the number of cutworms in the soil. For example, fall plowing breaks many of the cells in which the insect passes the winter as pupae, and pupae in these broken cells die. The effects of this practice will vary with the locality.

- If possible, avoid planting crops in fields with a known history of cutworm problems. Cutworm damage is most likely to occur when susceptible crops are planted in land that formerly was grassland, pasture, or meadow.

- Keep the land free of green vegetation by cultivation for at least 60 days before setting tobacco or plow in autumn or winter to keep winter weeds down. Partially starved wintering larvae produce moths that lay few or no eggs in the spring.

- Monitor adult flight activity and weather to predict when the crops are most vulnerable to attack. Another way to predict cutworm problems in a field is to place clumps of green vegetation (grass or clover) and check under the clumps in 4 to 7 days.

\section{- Natural enemies}

Many insect parasites and several diseases attack cutworms. However, due to the subterranean habit of the larvae, the effects of these natural enemies are seldom noticed, but without them cutworm outbreaks would occur more often $(43,82)$. Important natural enemies of the cutworms are birds, common predatory beetles, nematodes, and tachinid flies. In the United States, CRUMB (43) estimated that cutworms and other lepidopterous larvae make up more than $20 \%$ of the food of common bird species in May, the month during which cutworms do the most conspicuous damage under field conditions.

Heterorhabditis spp. (Heterorhabditidae) and Steinernema spp. (Steinernematidae) are highly virulent to black cutworm. Heterorhabditidae and Steinernematidae typically form an insect killing symbiosis with bacteria. Nematodes invade and traverse the gut of susceptible insects; they release bacterial symbionts in the insect blood (hemolymph), which suppress host immune responses and function as pathogens. In addition, several granuloviruses (e.g., 84-87) and entomopathogenic fungi (e.g., 88) have been used or investigated for the control of $A$. ipsilon and its congeneric $A$. segetum.

SALAMOV (89) gave examples of ichneumonid parasites of the cutworm A. segetum. A list of the hosts of tachinid flies, which include $A$. ipsilon, have also been complied (e.g., 90). A list of natural enemies of Agrotis spp. from Gujarat, India was published by PATEL et al. (91). In addition, other beneficial organisms that have been observed or evaluated for the control of Agrotis are given in CABI (92).

\section{- Chemical}

Larvae of the black cutworm can be very difficult to control with insecticide because of the subterranean habit of the most damaging stages (fourth instars and above) of the insect. It is, therefore, very important to detect and treat the young larvae as early as possible.

Some of the insecticides used or tested against black cutworms include acephate, bifenthrin, clothianidin, chlorantraniliprole, chlorpyrifos, chlorpyrifos-ethyl, cyfluthrin, lambda-cyhalothrin, Malathion, Trichlorfon, zeta-cypermethrin, and zeta-cypermethrin + bifenthrin. For example, chlorpyrifos applied as a pre-plant incorporated treatment and acephate applied in the transplant water are used as preventative treatments. Acephate and the others can be applied as foliar treatments if a problem develops after transplanting. Because cutworm infestations are sporadic, seed- or soiltreatment is only justified where perennial infestations occur (71). Soil treatments for control of cutworms are more effective if they are applied about 1 week before transplanting (93). 
TOBACCO HORNWORM - Manduca sexta Linnaeus, 1763

\section{Taxonomic position}

Order: Lepidoptera

Family: Sphingidae

\section{Common names}

Carolina sphinx moth; six-spotted sphinx moth; tobacco hawk moth; tobacco hornworm; goliath worm (as larvae)

Synonyms

Macrosila carolina Clemens, 1839

Manduca carolina Hübner, 1809

Phlegethontius carolina Hübner, 1819

Phlegethontius sexta Kirby, 1892

Protoparce carolina Butler, 1876

Protoparce griseata Butler, 1875

Protoparce jamaicensis Butler, 1876

Protoparce leucoptera Rothschild and Jordan, 1903

Protoparce sexta Rothschild \& Jordan, 1903

Protoparce sexta luciae Gehlen, 1928

Protoparce sexta peruviana Bryk, 1953

Protoparce sexta saliensis Kernbach, 1964

Sphinx caestri Blanchard, 1854

Sphinx carolina Linnaeus, 1764

Sphinx eurylochus Philippi, 1860

Sphinx lycopersici Boisduval, 1875

Sphinx nicotianae Boisduval, 1875

Sphinx paphus Cramer, 1779

Sphinx sexta Linnaeus, 1763

Sphinx tabaci Boisduval, 1875

\section{Damaging stages}

Larva

\section{Distribution}

Tobacco hornworm and the closely related tomato hornworm, Manduca quinquemaculata, both occur in North America from Canada to Florida, USA. However, M. sexta extends its range into Mexico, the Caribbean, Central America, and parts of South America. M. quinquemaculata is rarely found south of Florida. In the United States, both of these insects are found in tobacco fields, but $M$. quinquemaculata is more common in the northern part of the country, while $M$. sexta is the predominant species farther south.

\section{Plant hosts}

M. sexta larvae primarily feed on tobacco, but they will also feed on related solanaceous crops, such as Solanum lycopersicum, S. melongena, S. tuberosum, and Capsicum. In addition, Manduca have been observed to feed on flowers of several plants species. Datura stramonium, Nicotiana alata, N. reparida, Petunia axillaris (Solanaceae), Campsis radicans, Catalpa speciosa (Bignoniaceae),
Ipomoea pandurata (Convolvulaceae), Oenothera biennis (Onagraceae), Hemerocallis sp. (Asphodelaceae), Hibiscus lasiocarpus, Alcea rosea (Malvaceae), Crinum pedunculatum (Amaryllidaceae), Mirabilis jalapa (Nyctaginaceae), Lonicera sp. (Caprifoliaceae) Link \& Otto, and Albizia julibrissin (Fabaceae).

The preferred flowers appear to be D. stramonium and Catalpa $(94,95)$, and N. tabacum.

\section{Classification and description}

Manduca species are in the moth family Sphingidae, a member of the superfamily Bombycoidea. The larvae of the superfamily exhibit horns. Sphingidae or sphingid moths have a streamlined shape, narrow wings, and a swift and rapid flight that is reminiscent of a hawk, hence the name "hawkmoth". The common name "hummingbird moth" is also used because of their ability to hover at flowers while feeding like a hummingbird. They are also referred to as sphinx moths based on the habit of the larva rising up in a defensive position when startled, thus loosely resembling the Egyptian Sphinx (96).

The adult M. sexta (Figure 5) is a large moth, which averages about $5.8 \mathrm{~cm}$ long and $1.3 \mathrm{~cm}$ in diameter, with a wing spread of $11-12.8 \mathrm{~cm}$. Its head and thorax are gray to dark gray. The abdomen is dark gray with six conspicuous orange spots on each side of the abdomen segments 3-8, laterally outlined in black; and a white transverse band between and below the spots. Occasionally, the number of spots is reduced to five (96). M. quinquemaculata have five similar but less distinct spots on each side of abdominal segments 4-8; occasionally the number of spots is increased to six (96). In addition, the center of the hind wings of the tomato hornworm bears two distinct, zigzag or wavy lines, which are less distinct and darkened in tobacco hornworm. The moth of M. sexta has a small white area which extends from near the base of the forewing to the part of the thorax next to the base of the wing. This white area is absent in M. quinquemaculata. There are no differences in color and markings between the males and females in either species. In general, the females can be separated from the males in both species by their larger size, and they have narrower antennae than the males. Hornworms are crepuscular and nocturnal in habit.

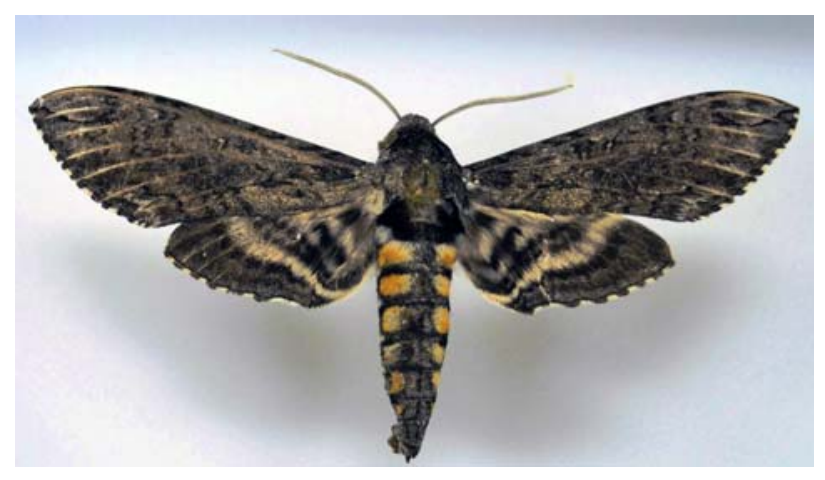

Figure 5. Adult tobacco hornworm (Manduca sexta) (photograph by Peter Edde). 


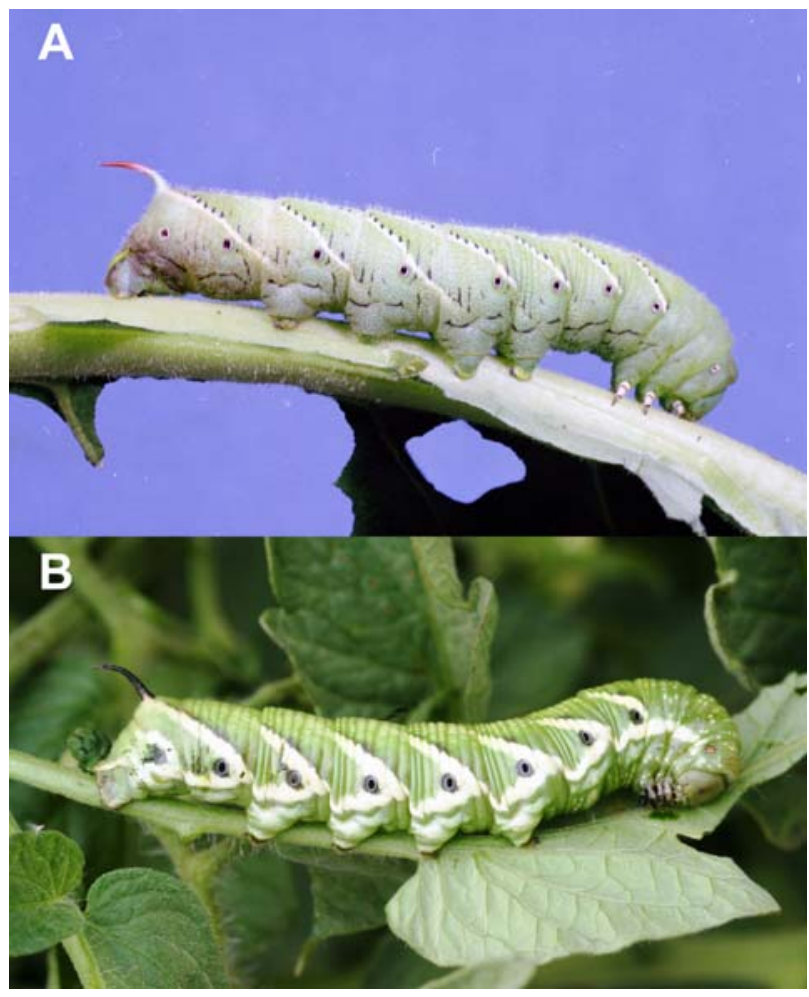

Figure 6. (A) Tobacco hornworm (Manduca sexta) larva and (B) tomato hornworm (Manduca quinquemaculata) larva (photographs by Whitney Cranshaw, https://Bugwood.org, with permission).

\section{Damage}

Hornworm larvae (Figure 6) are a major economic pest in tobacco because they consume tobacco leaves (Figure 7), the main marketable part of the crop. Two large hornworms can completely defoliate a tobacco plant, leaving only midribs and stem. The larvae spend almost all their time, both day and night, eating. The fourth and, especially, the fifth instar larval are particularly damaging because of their voracious eating habit. In addition to the loss in weight of cured tobacco due to hornworm feeding, the market value of the damaged leaves is lower because of their unfavorable appearance (95).

\section{Biology and ecology}

The biology of the $M$. sexta has been described by MADDEN and CHAMBERLin (94), MORGAN (97), and Gilmore (95), and that of M. quinquemaculata by SVEC (98), BANHAM (99), and MADDEN and CHAMBERLIN (100). The following is a summary of the biology of the hornworms as described for $M$. sexta, which is similar to that of M. quinquemaculata. M. sexta spends the winter in the pupal stage 10 to $18 \mathrm{~cm}$ below the surface of the soil. The adult begins to emerge in mid-April, and emergence continues until the middle of August or later, depending on the location.

Studies conducted at $24^{\circ} \mathrm{C}$ under LD 16:8 cycles showed that the female $M$. sexta begins to attract males for mating within $2 \mathrm{~h}$ during the early scotophase (101). Semiochemicals associated with the calling behavior of the moth

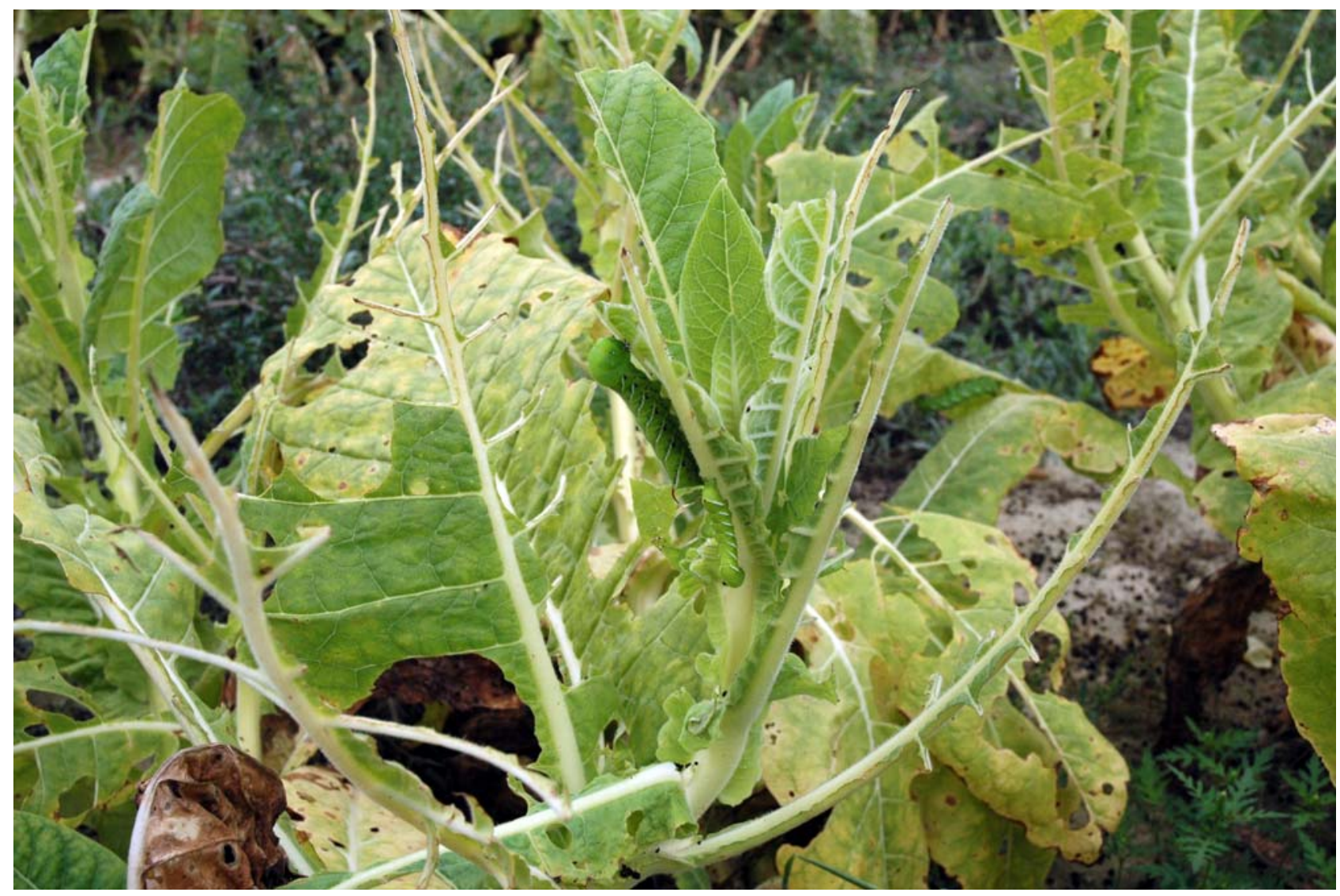

Figure 7. Defoliated tobacco stalks caused by hornworm (photograph by Whit Morris, with permission). 
have been described (102-104). For example, TUMLINSON et al. (103) isolated and identified 12 compounds from pheromone glands excised from calling female $M$. sexta. The compounds are (Z)-9-hexadecenal, $(Z)$-11-hexadecenal, (E)-11-hexadecenal, hexadecanal, $(E, Z)$-10,12-hexadecadienal, $(E, E)$-10,12-hexadecadienal, $(E, E, Z)$-10,12,14-hexadecatrienal, $(E, E, E)-10,12,14$-hexadecatrienal, $(Z)$-11-octadecenal, (Z)-13-octadecenal, octadecanal, and (Z,Z)-11,13-octadecadienal. However, only two of the compounds, $(E, Z)-10,12-$ hexadecadienal and $(E, E, Z)-10,12,14$-hexadecatrienal, are required to elicit the full sequence of behaviors exhibited by male $M$. sexta in response to the natural pheromone blend. The authors suggest that the remaining ten components of the blend play subtle, but undefined roles in the communication system of the moth.

In captivity, mating usually occurs during the second or third night after emergence, and it often lasts $1 \mathrm{~h}$ or longer (95). Oviposition occurs in the succeeding scotophases if a tobacco plant is present (101). Females deposit their first egg in about 1.8 days after they emerge, and most ovipositing females would have begun egg laying by the third to fourth day after emergence $(94,97)$. Many of the eggs are deposited within 6.4 days (94). The eggs are deposited singly, preferably on the marginal underside of the distal one-third of the leaf. MADDEN and CHAMBERLIN (94) reported that female moths reared on tobacco leaves from field-collected larvae laid an average of 300 eggs per female, but the moth can lay as many as 1133 eggs. The eggs, which are about $1.48 \mathrm{~mm}$ long and $1.34 \mathrm{~mm}$ wide, are spherical and flattened above and below. Newly laid eggs are light green in color, and with very little surface sculpturing. The eggs turn a lighter tinge of green within about $24 \mathrm{~h}$ after being laid, then they turn to yellow, and finally white before hatching.

The average incubation period under summer conditions is about 4 days, but could extend to 8 days depending on temperature. The mean weight of a newly hatched larva is about $1.4 \mathrm{mg}$. The newly hatched larvae first feed on the egg shell before migrating to feed on leaves. Sphingid larvae are easily recognized by the presence of a stout, fleshy horn at the posterior abdominal segment, and by $6-8$ annulets on each body segment. Saturniidae and Notodontidae may also have the caudal horn, but they lack the annulets (105). The horn in M. sexta larvae (Figure 6) is slightly curved backward. In matured larvae, the horn is orange, yellow red, or reddish in color, while that of M. quinquemaculata is straight and dark green with black sides. Both also have oblique white strips on the side of the body. There are seven of these stripes in $M$. sexta larvae, and they extend farther up on the back of the larvae, whereas in M. quinquemaculata larvae (Figure 6), there are eight V-shaped stripes, with each of the "V" marks pointing anteriorly and embracing each spiracle except the anterior one, and the stripes do not extend farther up the back of the larvae. The larvae of the two species are difficult to separate in the first two instars. Later, the lateral markings, color, and position of the horn are useful in separating the species. The full-grown larvae of both species are about 75-85 mm long and 12-14 mm wide (95).

The larvae usually undergo five instars in about a month or less when reared on tobacco. A sixth instar larval is possible, but very rare. The first instar larvae have silk glands that produce a strand on which they could descend. Second, third, and fourth instar larvae typically ingest part of their cast skin soon after molting and before feeding on the plant (106). At $25^{\circ} \mathrm{C}$ and $12 \mathrm{~h}$ photophase, the average length of time spent in the first through fifth instar is about 2.3, 2.0, $2.2,3.1$, and 8 days, respectively (106). The average body length of the first through fifth instar larva is about 6.7, $11.2,23.4,49.0$, and $81.3 \mathrm{~mm}$, respectively (94). The amount of food consumed by the larvae markedly increases with successive stadia, the increase being greatest during the fifth or last stadium. At $25^{\circ} \mathrm{C}$ and $12 \mathrm{~h}$ photophase, the average duration of the prepupal stage is about 3.6 days (106). As shown earlier, the mature larvae burrow into the soil to a depth of about $14 \mathrm{~cm}$ (range, 10-18 cm), form an earthen cell, and then transform to pupae (95).

Pupae (Figure 8) are light to deep brown, elongate-oval in form, and pointed at the posterior end. They are about $40-60 \mathrm{~mm}$ in length. In the tobacco hornworm, the tip of the structure that encases the mouthparts, the maxillary loop, extends backward touching the body about one-third the distance from the tip of the abdomen and in front of the

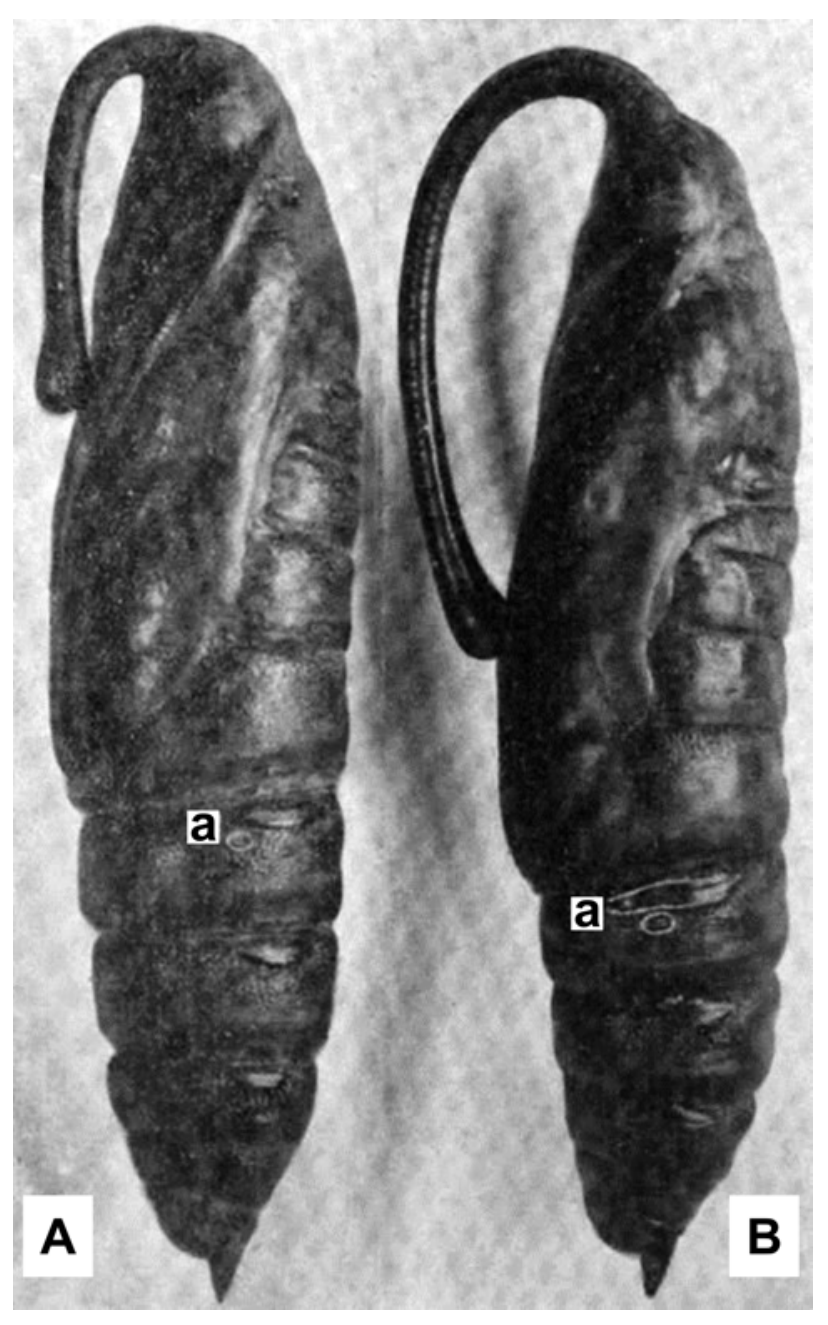

Figure 8. Pupa of the tobacco hornworm, showing (A) the groove in the fifth abdominal segment stopping at spiracle at "a" and (B) the groove in the fifth abdominal segment extending to "a" below the spiracle. Pores and groove are outlined to render them more conspicuous [adapted from GARMAN and JEWETT (265)]. 
tip of the antennae. The groove before the spiracle of the fifth abdominal segment in tobacco hornworm is short, not extending ventral to spiracle. The tip of the maxillary loop in the tomato hornworm touches the body posterior to, or opposite, the tips of the antennae and at about the middle of the length of the body. Groove is anterior to spiracle of fifth abdominal segment long, extending ventral to spiracle. MORGAN (97), working in Kentucky and Tennessee, USA, noted that most larvae that pupate not later than the last week of July emerge as adult moths of the second generation in about 3 weeks. Those that pupate mid- to lateAugust will usually hibernate and will not emerge as adult moths until the following year. REINECKE et al. (106) observed the duration from pupation to adult emergence is about 22 days in non-diapausing pupae, and about 97 days for diapausing pupae. Adults tend to take to flight about $3.5 \mathrm{~h}$ after eclosion. MORGAN (97) estimated an average of 48 days for the completion of the life cycle from egg to adult. Longevity of adult males range from a minimum of 1 day to a maximum of 19 days, with an average of 6.7 days, and females live from 1 day to 20 days, with an average of 8.8 days (94).

The number of generations in a year varies depending on location. For example, in the United States, two generations are common in Maryland, Virginia, North Carolina, Kentucky, and other tobacco growing regions in the south. Three complete generations, with the possibility of a fourth are possible in other locations, where the moths appear earlier. For example, field observations by MADDEN and CHAMBERLIN (94) in Florida showed that adults emerge from the overwintering pupae from the middle to the latter part of April, just in time to deposit their eggs on newly transplanted tobacco. The eggs begin hatching about the end of the month. Due to lower temperatures, as compared to summer months, the development of the insect is slower in the spring, needing about 8 weeks and 25 days to complete larval and pupae development, respectively. Thus, the first generation is completed about early- to mid-June. The second generation needs about 48 days and is completed about the first week in August. The third generation is completed about mid-September, thus allowing sufficient time for the completion of a fourth generation before the advent of wintry weather.

\section{Management}

\section{- Scouting technique}

Tobacco and tomato hornworms are first noticed at 3-4 weeks after transplanting, but they are most common after topping and through harvest. Therefore, weekly scouting for small larvae is very important; as it would help to detect infestation before populations of large larvae reach damaging levels. Newly hatched larvae may be found on the upper surfaces of leaves. As they grow, they tend to be on the underside of the leaves. Large larvae are obvious and easy to detect. They typically feed within the upper half of plants and are usually found near their feeding site. As they feed, their barrel-shaped feces drop down and are collected on the leaves underneath the leaf with the worm, or on the ground if the plant has been severely defoliated. Larval populations can also be estimated on crop by using a sweep net or a beating tray/sheet (a white sheet or tray slid under the plants and shaken to dislodge the larvae) method. However, sweeping and shaking tobacco leaves may injure the plants and even knock off leaves.

Recommendations on tobacco sampling method for pest management decision making purposes are like those described previously in the section that discussed the tobacco aphids (see page 122).

\section{- Action threshold}

Threshold recommendation in major tobacco growing region of the United States is largely based on larval size, especially healthy larvae. In Virginia, USA, SEMTNER(107) recommended insecticide application to avoid economic loss when there are one or more larvae at least $25.4 \mathrm{~mm}$ long and without parasites (Cotesia congregata cocoons) found per 10 plants examined (i.e., 10\% infestation). For hornworms 12.7 to $19.1 \mathrm{~mm}$ long, the author recommends treatment when 1 hornworm is observed per plant.

\section{- Non-chemical}

Important cultural control measures include the following strategies:

- Hornworm pupae overwinter in the ground, about 100 to $177 \mathrm{~mm}$ deep. This depth is within reach of typical soil tillage implements. Consequently, fall and winter plowing of tobacco fields after harvest is completed will help to expose most of the overwintering pupae to predation and reduce the overwintering population in the spring (95).

- Tobacco hornworms have the potential for producing a large overwintering population toward the end of the growing season, when most cultural or chemical control practices have ceased. Therefore, stalk and root destruction and early plowing at once after harvest helps to reduce the amount of available food for the hornworm and other foliage feeding insects (budworms, flea beetles).

- Hand picking and destruction of larvae is often practical and effective in small fields or home gardens, at least until the middle of the year or later.

- Topping tobacco in the button or early flowering stage makes the plant a less desirable host for hornworms.

- Effective sucker control reduces food sources for hornworms and other tobacco pests such as budworms, and aphids (107).

- In the United States, for example, hornworms are more abundant during the late summer and early fall. Earlyplanted tobacco is less likely to suffer hornworm damage because it matures earlier and is a less desirable oviposition site than younger, more succulent plants and will, therefore escape the later hornworm generation.

- Adoption of agronomic practices that encourage populations of natural enemies.

- The use of sterile (irradiated) male techniques to potentially control $M$. sexta has been demonstrated in isolated locations by SNOW et al. (108).

- Blacklight traps can help reduce moth populations. 


\section{- Natural enemies}

There are many natural enemies of hornworms, including vertebrates, other insects, and several microorganisms:

- Bacteria - The bacteria Serratia spp. (Enterobacteriaceae), Pseudomonas spp. (Pseudomonadaceae), Bacillus spp. (Bacillaceae), and Enterobacter spp. (Enterobacteriaceae) are among the most predominant and effective pathogens of lepidopteran larvae, including the hornworms. For example, B. sphingidis causes hornworm septicemia disease. Symptoms and postmortem changes in hornworms suffering from the disease have been described by WHITE (109). First, infected larvae lose their appetite and exhibit dysenteric (watery feces) conditions. Late during the disease, a thin "vomitus" oozes from the mouth, and the larva loses the characteristic turgidity associated with healthy larvae. Dead larvae can be found hanging head downward on plants by the hooks of a proleg. Soon after death the body of the larva becomes light brown, and finally turns almost black. The voracious feeding of hornworm larvae provides a good opportunity for them to ingest bacterial pathogens with their food.

- Diptera - The tachinid flies Archytas marmoratus, Palexorista laxa, Peribaea orbata, Sturmia incompta, and Winthemia manducae cause mortality in budworm and hornworm in either the prepupal or the pupal stage of the tobacco hornworm. W. manducae, for example, deposit eggs on the integument of the last instar larval of the host. However, hatching of the egg is delayed until the host prepupae molted in its cell in the soil; thus, the parasitic larva can enter the host pupa before its integument hardens. The tachinid larvae develop inside the host pupa. The developing fly larvae kill hornworm pupae. The fly larvae mature in about 7 days and exit the host to pupate in the soil.

- Hemiptera - Stilt bug adults and nymphs (Jalysus spinosus) (Berytidae) prey on tobacco hornworm and tobacco budworm eggs, while the big-eyed bugs ( $\mathrm{Geo}$ coris spp.) (Geocoridae) attack the larvae. The spined soldier bug, Podisus maculiventris (Pentatomidae), preys on a wide variety of other arthropods, especially larval forms of Coleoptera and Lepidoptera, including M. sexta.

- Hymenoptera - The vespid wasps Polistes species (Vespidae) prey on hornworm and other lepidopteran larvae as food for their young ones. For example, RABB (110) observed that up to $10 \%$ of hornworm larvae in a tobacco field in North Carolina, USA were killed by $P$. fuscatus alone. Hornworm larvae are attacked by the wasps Meteorus sp. and Cotesia congregata (Braconidae). The parasitoid injects eggs into first to third instar larvae. The eggs hatch and the young larvae feed on the hemolymph of the host, while the host stays alive. Offspring emerge from fourth and fifth instar larvae. In the case of Cotesia, the mature larvae stay inside the host and spin many white cocoons protruding from the hornworms body. The life cycle of Meteorus species is similar to that of $C$. congregata, but the larvae of the former do not spin white cocoons. Instead, just before the host pupates, mature Meteorus larvae exit the host, move to a nearby leaf or twig, form a silk pad on the substrate, and pupate (111). In both Cotesia and Meteorus sp., the host soon dies after parasites emergence from the pupae or larva, respectively. Important hymenopterous parasites of the egg stage include several Trichogramma species (Trichogrammatidae). The ichneumonid wasp Hyposoter exiguae (Ichneumonidae) is also an effective endoparasite of several species of lepidopteran larvae, including $M$. sexta. The biology of $H$. exiguae has been described by PUTTLER (112). Other hymenopterous endoparasites of lepidopteran larvae, including M. sexta, are Goniozus legneri (Bethylidae), Cardiochiles nigriceps, (Braconidae), Euplectrus spp. (Eulophidae), Campoletis spp., Hyposoter spp. (Ichneumonidae), Telenomus spp. (Scelionidae), and Vespula vidua (Vespidae).

- Nematode - The larval stages of hornworm are susceptible to parasitic nematodes such as Heterorhabditis bacteriophora (Heterorhabditidae), Steinernema carpocapsae, and $S$. Riobrave (Steinernematidae).

- Neuroptera - Chrysoperla spp. (Chrysopidae) are important biological control agents of the egg stage of tobacco hornworm.

- Vertebrates - Skunks (Mephitidae), and moles (Talpidae) prey in large numbers on the prepupae and pupae of both species of hornworms. These vertebrates can find them several centimeters below the soil surface $(95,100)$.

- Virus - Granulosis virus (Baculoviridae) and cytoplasmic polyhedrosis viruses (Reoviridae) occur naturally and often cause natural outbreaks (epizootics) in hornworm populations.

- Araneae - Aysha gracilis (Anyphaenidae), Acanthepeira stellata (Araneidae), Cheiracanthium inclusum (Miturgidae), Oxyopes salticus, Peucetia viridans (Oxyopidae), Phidippus audax (Salticidae), Misumenops celer, Misumenops sp. (Thomisidae).

- Coleoptera - Calathus opaculus (Carabidae), Cycloneda munda, Hippodamia convergens, Coleomegilla spp. (Coccinellidae), and Collops balteatus (Melyridae).

- Other predators that exert occasional check on hornworm populations, especially after root and stalk destruction, include several species of wild birds and domestic fowls, especially chickens and turkeys.

\section{- Chemical}

Bacillus thuringiensis (Bt) products, (e.g., Bacillus thuringiensis ssp. kurstaki), in a spray formulation are effective as preventative treatments throughout the entire growing season. However, Bt endotoxin crystals are more effective if the toxin is ingested when larvae are small and in their early developmental stages.

The following insecticides can be applied for suppression of larval populations: acephate, bifenthrin, chlorantraniliprole, cyhalothrin, and cyhalothrin + thiamethoxam and cyhalothrin + chlorantraniliprole, and bifenthrin + imidacloprid, chlorantraniliprole + lambda-cyhalothrin, abamectin benzoate, flubendiamide, indoxacarb, methomyl, and spinosad. Hornworms are easier to control than tobacco budworms. 
BUDWORMS - Tobacco budworm (Heliothis virescens Fabricius, 1777) - Cotton bollworm (Helicoverpa armigera Hübner, 1808)

\section{Taxonomic position}

Order: Lepidoptera

Family: Noctuidae

\section{Common names}

See the common names of the respective species.

Damaging stages

Larva

\section{Distribution}

See the distribution of the respective species.

\section{Plant hosts}

All species of Heliothis and Helicoverpa feed on a very large variety of wild and cultivated herbaceous plants. The larvae of the species feed on foliage, although they prefer buds, inflorescences, fruits, and pods of their hosts. This feeding behavior contributes to the potential injuriousness of the pests and causes them to directly influence crop yield.

$H$. virescens tobacco budworm infests more than 19 crops and at least 80 wild plants (113). Although $H$. virescens is very damaging on tobacco, Desmodium spp. (Fabaceae) are its preferred food plants. Tobacco budworm is also known to cause severe economic loss in Gossypium spp. (Malvaceae), Solanum lycopersicum (Solanaceae), Hibiscus spp. (Malvaceae), Helianthus (Asteraceae), and Glycine max (Fabaceae). Larvae have also been consistently recovered from S. tuberosum (Solanaceae), Cicer arietinum, Pisum sativum, Lathyrus odoratus (Fabaceae), Brassica oleracea (Brassicaceae), Strelitzia reginae (Strelitziaceae), Chrysanthemum (Asteraceae), Geranium (Geraniaceae), Abelmoschus spp., Abutilon theophrasti (Malvaceae), Medicago sativa, Trifolium spp. (Fabaceae), Linum sp. (Linaceae), and several species in the genus Antirrhinum (Plantaginaceae) and genus Ageratum (Asteraceae).

$H$. armigera larvae have been recorded as damaging 180 species of plants as hosts distributed in about 45 families. The food plants of the species appear similar to those of Heliothis. The most important cultivated plants damaged are Sorghum, Zea mays (both Poaceae), and Gossypium (Malvaceae). In addition, BEGEMANN and SCHOEMAN (114) reported that citrus is a principal host of $H$. armigera in the drier parts of South Africa in spring when alternative hosts have yet to blossom.

$H$. armigera and $H$. assulta have similar feeding behaviors, but their host-plant ranges are quite different. Unlike $H$. armigera, which is a highly polyphagous species, $H$. assulta is oligophagous feeding primarily on Solanaceae species such as Nicotiana, Physalis, and Solanum species.

\section{Classification and description}

Heliothis and Helicoverpa are two genera of heliothine, in moth family Noctuidae. Diagnostic features of the family have been described above in the section that discussed the black cutworm moth, A. ipsilon (see page 124).

Tobacco Budworm — Heliothis virescens Fabricius, 1777

\section{Common name}

Tobacco budworm

Synonyms

Noctua virescens Fabricius, 1777

Phalaena rhexiae Smith, 1797

Xanthia viridescens Walker, 1857

Xanthia prasina Walker, 1857

Heliothis spectanda Strecker, 1876

Chloridea virescens Dyar, 1903

\section{Distribution}

Heliothis virescens is a native of North America. It is found throughout the United States and southern Canada, and it is widely distributed throughout the Americas. In the United States, the insect is most damaging to crops in the southwestern States, where it successfully overwinters in the pupal stage. Tobacco budworm does not survive the winter in northern states' populations, and moth populations found in northern United States and southern Canada during the late summer are believed to be migrant populations from the overwintering sites in the south.

\section{Classification and description}

The tobacco budworm is placed in the genus Heliothis. HAMPSON (54) gave a description of the genus Heliothis. The eyes are naked and without lashes. The proboscis is fully developed. Palpi extend forward, projecting, and the second segment is evenly covered with long setae. The third segment is short and depressed and a short frontal shift. The thorax and abdomen are without tufts. Fore tibia has a pair of slender terminal spines, and the mid and hind tibiae are also spined. Fore wings with veins 8 and 9 are sometimes given off from the end of the areole.

The adult form of the tobacco budworm (Figure 9) is light green with brown overtones. Wing expanse averages about 30-38 mm. Three dark bands, each accompanied by a whitish or cream-colored border, cross the front wings transversely. The hind wings are whitish or cream-colored and are bordered with a brownish or dark band. $H$. virescens is often difficult to distinguish from other species of the virescens complex, especially $H$. subflexa (Guenee). However, the two species can be separated using the outer band on their front wings. The outer band ends before reaching the apical angle in $H$. virescens, while the outer band ends at the apical angle in $H$. subflexa. The adults of the other four species in the $H$. virescens complex [H. subflexa (Guenée), H. tergeminus (Felder and Rogen 


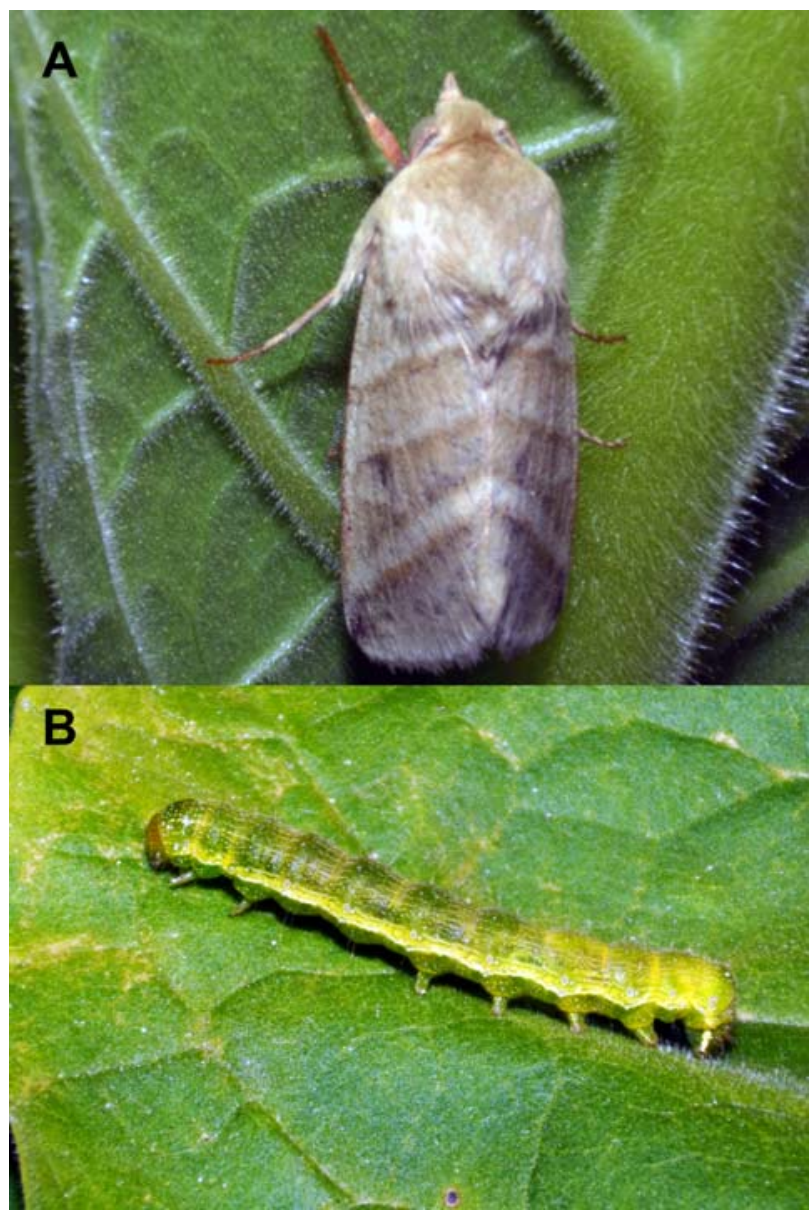

Figure 9. Tobacco budworm moth, Heliothis virescens, with folded wings: (A) adult and (B) larva (photograph by Peter Edde).

hofer), H. distinctus (Schaus), and H. molochitinus (Berg)] can also be separated from each other using the maculation characters on their front and hind wings.

Fully grown larvae (Figure 9) are about $38.5 \mathrm{~mm}$ long. Usually, they are light green and have several longitudinal pale green stripes running lengthwise on the body, but color may range from green to yellowish brown or dark reddish brown, depending on the environment (e.g., exposure to light, temperature, color of the flowers on which the insects are feeding) and heredity.

The early larval instars of tobacco budworm are similar in appearance to those of the corn earworm Helicoverpa (= Heliothis) zea (Boddie), but NeUNZIG (115) provided a key to aid in separation. Older tobacco budworm larvae (third instar and above) have a tooth-like projection on the inside surface of the mandible and microspines or small tooth-like projections on the first, second, and eighth abdominal projection (tubercles) that are about half the height of the tubercles. The projections and hairs are absent in H. zea.

Cotton Bollworm - Helicoverpa armigera Hübner, 1808

\section{Common names}

Due to its worldwide distribution and ability to cause damage on many cultivated crops, $H$. armigera is known under various common names in different regions of the world including African cotton bollworm or American bollworm in Africa, and Old World bollworm in Europe and Asia. Other common names include gram pod borer, tobacco budworm, tobacco worm, cotton bollworm, tomato fruit worm, tomato grub, maize cobworm, corn earworm, peaworm, lupinworm, top grub, citrus bollworm, scarce bordered straw, and carnation budworm.

\section{Synonyms}

Noctua barbara Fabricius, 1794

Heliothis armigera Hübner, 1805

Noctua armigera Hübner, 1805

Chloridea armigera Hübner, 1808

Chloridea obsoleta Duncan \& Westwood, 1841

Heliothis conferta Walker, 1857

Heliothis pulverosa Walker, 1857

Heliothis uniformis Wallengren, 1860

Heliothis fusca Cockerell, 1889

Helicoverpa commoni Hardwick, 1965

Heliothis rama Bhattacherjee \& Gupta, 1972

\section{Distribution}

Helicoverpa armigera is widely distributed across Africa, central and south-eastern Asia, Australia, Europe, India and New Zealand. Although the species is often intercepted at ports of entry in the United States since 1985, it has not yet been established in the country. However, in South America, $H$. armigera has been confirmed to be the present in Brazil (116), Argentina, and Paraguay (117), placing North America at risk of invasion by $H$. armigera .

\section{Classification and description}

Helicoverpa is a worldwide genus consisting of 20 described species. Originally, the species that are nowadays in the genus Helicoverpa were placed together with others under Heliothis. However, HARDWICK $(118,119)$ proposed the genus Helicoverpa based on the following characteristics: (i) they differ from the dispacea (Linnaeus) type species of Heliothis; (ii) no generic name is available for the group; and, more importantly, (iii) characteristic differences in the male and female genitalia, make them a natural generic entity discrete from Heliothis. In doing so, he recognized five species groups within the genus Helicoverpa: the Punctigera group (in Australia), the Gelotopoeon group (South America), the Hawaiiensis group (Hawaii), the Zea group (throughout the world) and the Armigera group (Old World) (118). Related historical notes on the nomenclature of $H$. armigera can be found in the works by COMMON (120), TOOD (121), PEARSON (122), FORBES (123), KiRKPATRICK (124), HARDWICK $(118,119)$, and SINGH (125).

SARWAR et al. (126) gave the description of the genus Helicoverpa as follows: frons mostly smoothed with a corneous plate below; head and thorax roughly haired; mid and hind tibiae spine in some species; fore tibiae tiny and wide, spines at sides, with one or two long claws on outer side and a short claw or three claws on inner side; the discal cell is more than half as long as fore wing, but in hind wing 
much shorter than fore wing, veins 3, 4, 6 and 7 on long stalks; forewing long and narrow with prominent apex but hind wing broader and shorter.

HARDWICK (118) published keys to the groups and to their species. KIRKPATRICK (124) provided the morphological description of four Heliothis species, including H. armigera, up to their immature stages. PEARSON (122) provided a description of the adult $H$. armigera. The adult moth (Figure 10) is stout-bodied with a typical noctuid moth appearance, broad across the thorax and thence tapering, having wing span of 35-40 mm and body length of $18 \mathrm{~mm}$. Color is variable, but usually from dull yellow or olive-grey to brown, sometimes with a pinkish suffusion, particularly on the underside. Forewings have a black or deep brown kidney-shaped marking near the center, and surrounded squarish brown ring, with a row of seven or eight black spots along outer margin. Hind wings are creamy white with a deep brown or dark gray band on outer margin. $H$. armigera is identical to $H$. zea (the corn earworm). The wing color of these two Helicoverpa species is quite variable. Therefore, authoritative identification of the adult $H$. armigera needs dissection of genitalia $(118,120,124)$. Both males and females are similar in appearance, except females are slightly bigger and have tufts of hair on the tip of the abdomen.
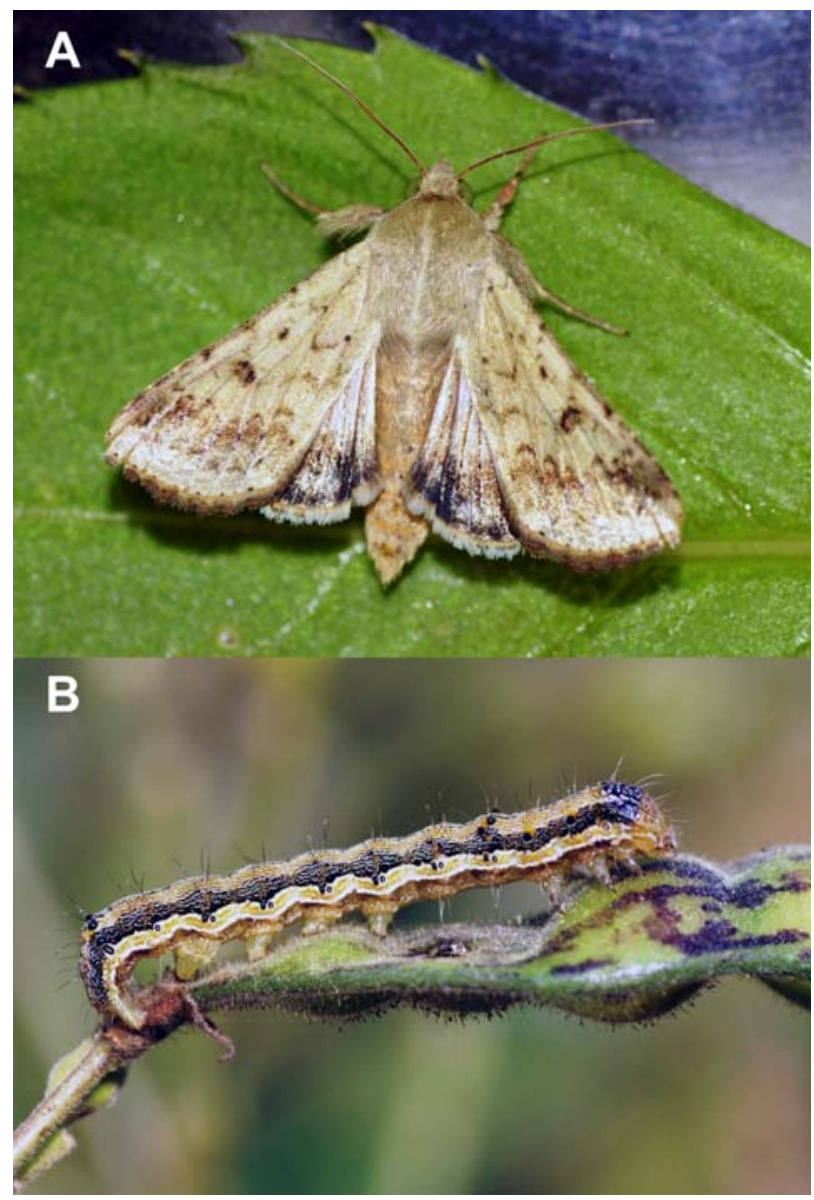

Figure 10. Helicoverpa armigera (A) adult and (B) larva (photograph courtesy of ICAR-NBAIR, India).

\section{Synonyms}

$H$. assulta Guenée (oriental tobacco budworm) is closely related to $H$. armigera and $H$. zea. $H$. assulta is migratory and widely distributed in Asia, Africa, Australia, and Oceania. Other names by which $H$. assulta has been described in the literature include the following:

Heliothis assulta Guenée, 1852

Helicoverpa separata Walker, 1857

Helicoverpa temperata Walker, 1857

Helicoverpa succinea Moore, 1881

Chloridea assulta Hampson, 1903

Helicoverpa afra Hardwick, 1965.

H. assulta is a serious pest in China where it often occurs sympatrically with $H$. armigera (127). In confinement, the two species can mate and produce viable offspring. However, under natural conditions, because of differences in their pheromone communication systems, they seldom attract each other for mating (128).

Morphologically, all stages of $H$. armigera and $H$. assulta are very similar in appearance. However, the former is slightly broader. The hind wings of both species have a dark terminal area interrupted by a small pale patch between veins $\mathrm{M}$ and CU. COMMON (120) provided the following key to separate the adult moths of $H$. armigera and H. assulta in Australia.

1. H. armigera: Hind wing with basal area whitish; valva in male broad, aedeagus usually with a distinct sclerotized thorn at base of vesica; lumen of ductus seminalis in female densely clothed with fine spinule.

2. H. assulta: Hind wing with basal area ochreous yellow; valva in male narrow, aedeagus without a thorn or similar process at base of vesica, rarely with minute thorn; lumen of ductus seminalis in female without spinules.

The full-grown larva of $H$. armigera (Figure 10) is about $35-40 \mathrm{~mm}$ long. The larval body color is highly variable. RANJITH (129) observed up to seven larval color types on tomato in India: light green, light green with orange spots, greenish, green with dark green dorsal lines, green with black lines and spot, brown with orange spots, and brown with white lateral lines. The body usually has longitudinal lines or bands. The larval skin has a characteristic granular appearance, with the surface consisting of close set, minute tubercles (122). AMATE et al. (130) presented a key for the identification of $H$. armigera and other economically important noctuid pests in Spain, based mainly on the study of chaetotax. Li et al. (131) provided photographical images of important morphological structures to separate larvae of $H$. armigera and $H$. assulta. Molecular methods have also been used to distinguish $H$. armigera from morphologically similar congeneric, regardless of the life stage (129).

\section{Damage}

Budworm damage to the tobacco plant is caused only by the larva. Although some damage is done by larger larvae feeding on mature leaves, greater damage is inflicted on the small, immature bud leaves. In preflowering plants, the females lay eggs singly on the undersides of leaves; usually the fourth to tenth leaves below the bud. After topping, 


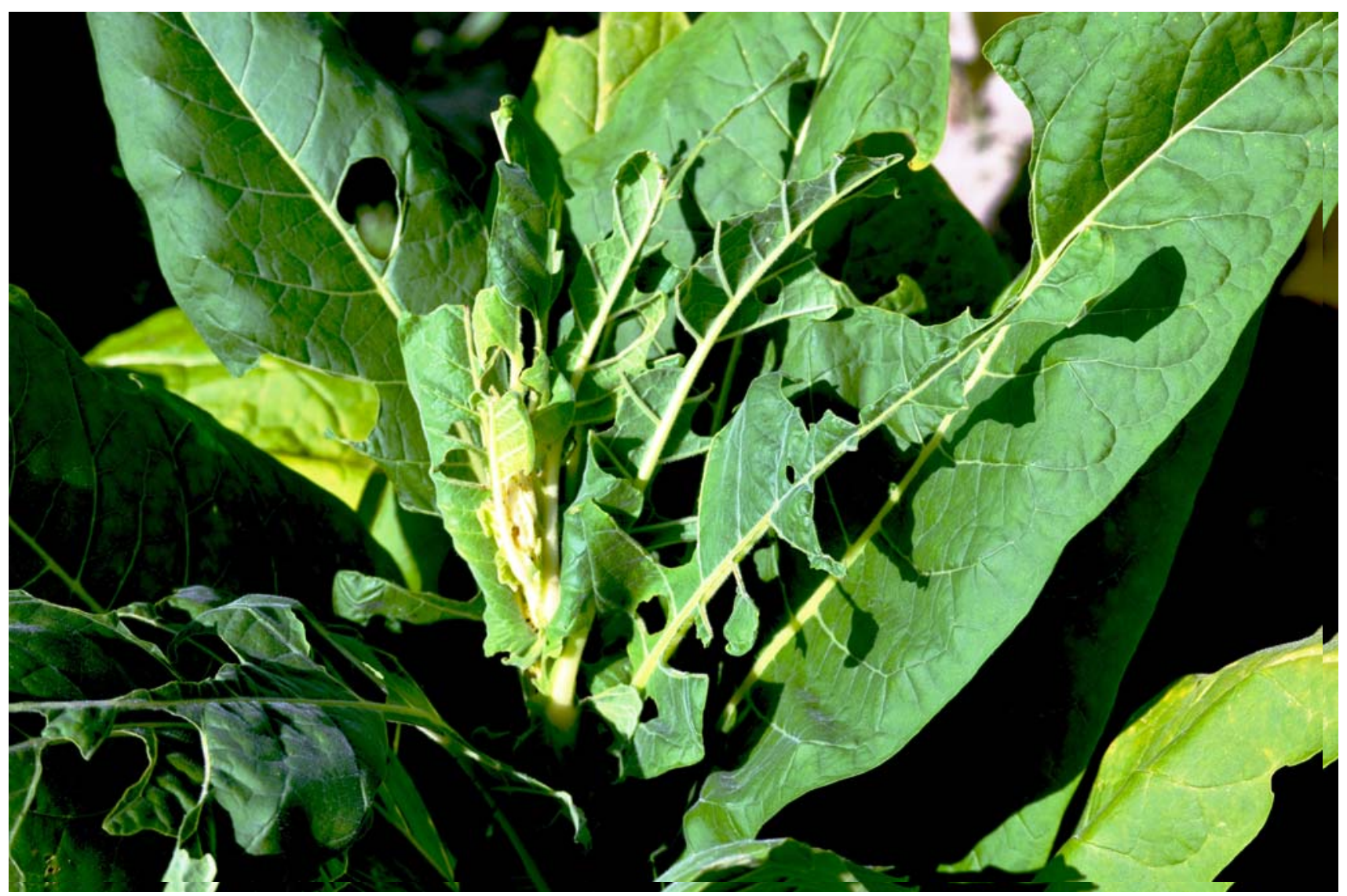

Figure 11. Injury to tobacco caused by the tobacco budworm (photograph by Peter Edde).

most eggs are laid on sucker leaves (132). The newly hatched larvae first feed on the egg shell and then from small areas on the leaf surface, leaving behind tiny holes about the size of a pinhead, before moving to the bud or tip of the undeveloped leaves of the plant, usually reaching it in about $24 \mathrm{~h}$ (133). On reaching the bud, the larvae conceal themselves between the immature leaves and begin to feed on the leaves. The leaves that expand from the buds are often ragged and distorted (Figure 11). Tobacco budworms sometimes top the plants prematurely causing early sucker growth that may stunt the plant and require extra labor to remove the suckers. Once the tobacco plants button, i.e., when the flower bud begins to show as the flower stem begins to elongate, budworm moths usually deposit eggs on the flower bud or opened flowers, destroying the flowers; the moths readily feed on the developing seed pods and leaves.

\section{Biology and ecology}

Details of the life history and behavior of $H$. armigera $(118,122,134,135)$ and $H$. assulta $(127,136-138)$ appear to be broadly similar to those of $H$. virescens (139-144). The following account on the biology and ecology of the species is based on that given for $H$. virescens, with an explanation of where they differ from the Helicoverpa species.

The tobacco budworm survives the winter as diapausing pupae in soil. The adults emerge in spring. The larvae typically begin to appear in tobacco about one month after transplanting. The adult budworm is active at night or at dusk, and most of its activity including mating and egg deposition occurs after dark. Intense flight activity occurs at night between the hours of 2100 and 2200, after which it stays low until 2300. Moth flight activity becomes intense again from midnight until about 0330 , during which most of the male movement occurs to find "calling" females. MING et al. (145) found that both $H$. armigera and $H$. assulta females called throughout the scotophase, and there was more calling during the second half of the scotophase than during the first half.

KLUN et al. (146) identified seven components of the femaleproduced sex attractant: (Z)-11-hexadecenal (77-91\%), (Z)-7-hexadecenal $(0.1-2 \%),(Z)-9$-hexadecenal $(0.3-2 \%)$, hexadecanal (3-19\%), (Z)-11-hexadecen-1-ol (1-5\%), tetradecanal (1-3\%), and (Z)-9-tetradecenal (1-3\%). However, the two most important compounds, as judged by their influence on the behavioral responses of the male budworms, are (Z)-11-hexadecenal and (Z)-9-tetradecenal $(147,148)$. The two components are inactive separately, but they are very effective in attracting males when mixed in the ratio 16:1, respectively, which is how they occur in the insect. Courting male $H$. virescens have been reported to emit (Z)-9-tetradecenal, which serves to repel other males of the species (149).

Similarly $H$. armigera and $H$. assulta both use (Z)-11-hexadecenal (Z11-16:Ald) and (Z)-9-hexadecenal (Z9-16:Ald) as their sex pheromone components [reviewed in MING et al. (145)]. Although $H$. armigera and $H$. assulta often occur sympatrically, as they do in China, the species have 
evolved several mechanisms to prevent interspecific mating and sexual isolation. For example, the ratios of the sex pheromone components differ significantly between the species. In $H$. armigera and $H$. assulta, the pheromone components Z11-16:Ald and Z9-16:Ald are produced in opposite ratios, 100:25 and 6:100, respectively, with Z11-16:Ald being the major sex pheromone component in H. armigera, whereas Z9-16:Ald is the major component in $H$. assulta (145). Differences in the temporal patterns of sexual behavior have also been identified as a factor in the reproductive isolation between the species. MING et al. (145) reported that the maximal pheromone titer and maximal calling activity in $H$. armigera synchronously occurred at the sixth hour into the scotophase, while in $H$. assulta, the maximal pheromone titer occurred $2 \mathrm{~h}$ before the peak of calling.

Ovipositing females need a minimum two-day preoviposition period, and oviposition typically occurs in most females by the fifth or sixth day (142). Oviposition usually lasts for about 2 weeks, and then, the insect dies, shortly after oviposition is completed. The female mostly prefers laying eggs on the upper surfaces of the terminal leaves and buds of tobacco plants. The freshly laid eggs are yellowish white, but turn yellowish after 1 day and become mahogany brown just before hatching. A female lays an average about 300-500 eggs over its lifespan. However, FYE and MCADA (142) noted that a female moth derived from a larva that was reared on an artificial diet at $20-25{ }^{\circ} \mathrm{C}$ laid about 900-1,600 eggs.

The egg stage of $H$. virescens has been described in considerable detail by NeUnZIG $(115,141)$. The eggs are $0.51-0.60 \mathrm{~mm}$ (average, $0.56 \mathrm{~mm}$ ) in diameter and $0.50-0.61 \mathrm{~mm}$ (average, $0.55 \mathrm{~mm}$ ) in height. They are spherical, with a flattened base with about 8-12 narrow vertical ridges (ribs) running from top to bottom. PEARSON (122) reported approximately 24 longitudinal ribs on $H$. armigera eggs. PHILLIPS (150) noted that the ridges on budworm eggs rarely touch the micropyle, while those of H. zea (Boddie) (cotton bollworm) usually fuse with the micropyle $(139,151)$. Freshly laid eggs are translucent white to yellowish-white, but darken within $48 \mathrm{~h}$, and the embryo appears as a reddish ring. The eggs assume a light brown to grayish appearance just before hatching. In summer temperatures, 3-5 days are needed for hatching. Budworm larvae normally go through six instars, but five or seven instars may occur before pupation. FYE and MCADA (142) noted that at $25^{\circ} \mathrm{C}$, it takes on the average $3.1,2.0,1.9,2.1,5.6$, and 2.5 days for the larvae to develop from instars one through six, respectively. Head capsule widths for larvae that develop through five instars measure $0.26-0.31,0.36-0.53,0.72-0.85,1.12-1.25,1.60-1.72$, and 2.40-2.82 $\mathrm{mm}$ for instars one through six, respectively. PATEL et al. (135) provided data on body length and head capsule widths for $H$. armigera larvae. Field data from southern United States show that 18-31 days are needed for the development of budworm larvae in May and June (133). At an average temperature of $27.7^{\circ} \mathrm{C}$, the larval feeding period on favored hosts was completed in 14 days. When about to pupate, the larva leaves the plant, sometimes by dropping to the ground, and burrows into the soil to a depth of about $25 \mathrm{~mm}$, and changes to the pupa in the soil within a packed earthen cell. NEUNZIG (152) provided a detailed description of the tobacco budworm pupa and provided a key to separate pupae of the species from those of Helicoverpa zea. Unique morphological characters are found in 3rd through 5th instar budworm larvae. Budworm larvae (3rd instar and above) have a tooth-like projection on the inside surface of the mandible (80). Another diagnostic character of budworm larvae is the presence of microspines on the 2nd and 8th abdominal projections (tubercles) that are about half the height of the tubercles. In contrast, $H$. zea larvae have smooth tubercles and mandibles lacking a cuticular process. PEARSON (122) described the H. armigera larvae.

Tobacco budworm pupae average $18.2 \mathrm{~mm}$ (range, $15.0-20.0 \mathrm{~mm}$ ) in length and $4.7 \mathrm{~mm}$ (range, 3.3-5.0 $\mathrm{mm}$ ) in width (152). FYE and MCADA (142) reported that 14-18 days are required for pupal development at $20-25^{\circ} \mathrm{C}$. The duration of the pupal stage under normal field conditions is about 6-10 days. If pupation occurs in late fall or winter, the insect stays a pupa until spring. PHILLIPS and NEWSOM (153) reported that pupae of both the cotton bollworm and the tobacco budworm could remain in diapause for at least 20 months at $18^{\circ} \mathrm{C}$. Pupae of both species are shiny, reddish-brown before turning mahogany brown due to adult pigmentation just before emergence. The moth appears from the pupa by crawling up the tunnel with its wings unexpanded, and it breaks through the thin crust of earth at the top, after which its wings expand. A generation of the tobacco budworm, from egg to adult, is produced in about 33 days during summer, but may be 46 days or longer in spring and fall (133). PATEL et al. (135) observed that the duration of the life cycle of the female is longer than that of the male in $H$. armigera, the average being 39 and 43 days, respectively. Most of the ovules of the female $H$. armigera are differentiated by the first day of pupation, and their development is continuous until the moth appears, at which time no ovules have reached the lower part of the ovarioles (122). In unfed moths, the body fat is rapidly used up, but the ovarioles remain small, and very few eggs become sclerotized; while in fed moths, the ovarioles swell rapidly, and ripe eggs are present on the second day after emergence from the pupa (122).

Temperatures have been shown to affect adult tobacco budworm longevity and fecundity. For example, peak egg laying was observed in the species at $25^{\circ} \mathrm{C}$, but fecundity was reduced for moths held at $35^{\circ} \mathrm{C}$ (144). Similarly, the longevity of both male and female moths declined as temperatures increased. FYE and MCADA (142) observed that survival ranged from 25 days for moths held at $20^{\circ} \mathrm{C}$ to 15 days at $30^{\circ} \mathrm{C}$.

Up to five generations of budworms may be observed per year, depending on location $(133,154)$. In the United States, the first two generations confine themselves almost entirely to tobacco, and the two populations overlap to a great extent (133). Populations of these generations are sufficiently large to keep tobacco fields thoroughly infested throughout the season. The third generation is present during the latter part of July and August. The third generations feed on late tobacco, and on beggarweed. A fourth and possibly a fifth generation also occur in the fall months. Larvae produced by these later generations pass the winter as pupae in the soil. 


\section{Management}

\section{- Scouting technique}

Budworm infestation may be noticed in tobacco fields 3-4 weeks after transplanting. The moth is active only at night. In daytime the moth is often found hidden among the tobacco leaves and will dart quickly to new hiding places when disturbed. Tobacco budworm adults are not readily attracted to black-light traps. Synthetic pheromone of the female-produced sex pheromone is readily available and can be used to monitor flight activity of the insect early in the season and continued until 1 to 2 weeks before topping. Trap counts help to detect when the moth begins its flying activity. It may also give a sign about the relative size of the budworm population, which helps to predict when budworm infestation should be expected.

Decisions as to when to apply insecticide should be based on larval infestations in a field. Start scouting for the larvae weekly following transplant until 1-2 weeks before topping. Tobacco budworm larvae prefer to feed on the bud and flowers, and rarely cause damage after the plant is topped, making it uneconomical to include tobacco budworm monitoring in the monitoring program after topping. Larvae feed on squares, flowers, and bolls. Holes and frass on these structures are a sign of infestation. It may be necessary to peel back the leaves to see the inside of the bud.

Treatment is based on the average number (and size) of larvae found or the percentage of damaged fruiting structures. Examine a group of 5 plants at a minimum of 10 locations in a field ( 1 to 10 acres) (107). Sample size should be increased if the field is larger. Budworm larvae feed on young leaves and especially the buds. Look for larvae and signs of injury in the top 5 nodes and examine at least one for white or pink bloom and one more boll in the mid canopy on each plant. Record the average number and size of larvae found per plant. A supplemental or alternative method is to examine 25 squares and 25 bolls in at least 4 locations in a field and record the number of squares and bolls with injury.

Leaves on lower parts of the stalks should be excluded from examination because holes present on these leaves are largely due to budworm damage that occurred earlier in the season and should not be included in scouting records. If larvae are not found within the bud, but larval feeding damage could be seen on leaves near the terminal bud or around the bud of the plant, the scout should carefully examine the tops and undersides of leaves immediately around the bud. After a careful check with no larva found, the affected plants should not be counted as infested.

\section{- Action threshold}

Treat when $10 \%$ of the observed plants are infested with live tobacco budworm larvae. It is essential to base treatment decisions on the damaged plants and the presence of larvae because leaf damage may be visible, but the larvae may have damaged the plant before being eliminated by parasites, predators, and diseases.

\section{- Non-chemical}

Although certain tobacco varieties have been identified as "tobacco budworm-resistant lines" [e.g., JUBA et al. (155)], tobacco varieties bred for resistance against the budworm have not yet been approved for release to growers.

Recommendations on cultural control measures for budworms are similar to those described previously for tobacco hornworms (see page 131).

\section{- Natural enemies}

All stages of the pest the tobacco budworm is preyed upon by a complex of beneficial organisms. A list of the arthropod natural enemies of $H$. armigera in India is given by ROMEIS and SHANOWER (156). LINCOLN et al. (140) and KOGAN et al. (157) provided a list of natural enemies of Heliothis species and corresponding stages of the species attacked. WATSON et al. (158) recorded predators belonging to at least 18 families preying on Heliothis spp. in the field in Alabama, USA. ROACH(159) described the parasites and diseases attacking Heliothis spp. in the field in South Carolina, USA. These publications suggest that most of the natural enemies described previously for tobacco hornworm will also attack the tobacco budworm. However, from the standpoint of economic importance, the three most important parasitoids that regulate budworm populations on tobacco in the United States are Campoletis sonorensis (Hymenoptera: Ichneumonidae), Cardiochiles nigricipes, and Microplitis croceipes (Hymenoptera: Braconidae). For example, KING et al. (160) reported that Campoletis spp. can parasitize up to $80 \%$ of the budworm larvae in a field. According to TILLMAN et al. (161), the three parasitic wasps are capable mechanically transmitting ascoviruses to budworm larvae during oviposition.

In the southeastern United States, ascoviruses can be prevalent in $H$. virescens, and $H$. zea (Boddie) larval populations in field crops, especially toward the end of the growing season (160). Viral enemies of tobacco budworms include Helicoverpa armigera stunt virus (HaSV) (Alphatetraviridae), Heliothis virescens ascovirus (HvAV) (Ascoviridae), Autographa californica nucleopolyhedrovirus (AcMNPV), Helicoverpa armigera nucleopolyhedrovirus (HearNPV), Helicoverpa zea single nucleopolyhedrovirus (HzSNPV), Plutella xylostella multiple NPV, and Rachiplusia ou multiple NPV (Baculoviridae).

\section{- Chemical}

Many of the materials registered for hornworm control, described previously, will also be effective on the tobacco budworm (see page 132). Because coverage is important, insecticide application should be conducted at dawn and at dusk when the buds are open. Insecticides application at these times, especially at dusk, also helps to minimize mortality exposure of beneficial insects and pollinators to the pesticide. To achieve large droplet sizes, apply foliar sprays for budworm control with 1 or 3 solid-cone or hollow-cone nozzles over each row using 40 to 60 psi (107).

Heavy use of pyrethroid insecticides has selected for resistance to the compounds in field populations of tobacco budworm. This first report of pyrethroid resistance in the insect 
in the United States was made in 1986. Four years later, resistance to the carbamates methomyl and thiodicarb and organophosphates profenofos, sulprofos, and acephate was detected in $H$. virescens populations collected from Louisiana and Mississippi (162). Molecular genetic evidences have been given to explain mode of resistance to pyrethroid insecticides in United States populations of $H$. virescens (162). As previously suggested above for aphids, resistance management strategies may rely, in part, on the sequential or temporal use of various classes of insecticides for control of the tobacco budworm (162).

\section{TOBACCO FLEA BEETLE - Epitrix hirtipennis Melsheimer, 1847}

\section{Taxonomic position}

Order: Coleoptera

Family: Chrysomelidae

\section{Common name}

Tobacco flea beetle

Synonyms

Epitrix parvula Fabricius, 1801

Crepidodera hirtipennis Melsheimer, 1847

\section{Damaging stages}

Adult and larva

\section{Distribution}

Tobacco flea beetle, Epitrix hirtipennis is native to North and Central America, and widely distributed wherever tobacco is grown in the United States. It also occurs in Canada, Mexico, Panama, Cuba, Bahamas, Puerto Rico, Ceylon, and the Philippine Islands. E. hirtipennis was noticed for the first time in Europe in the early 1980s in northern Italy. E. hirtipennis has now spread to other parts of the continent including Greece, Portugal, Bulgaria, former Yugoslav Republic of Macedonia, Turkey, Syria, and Russia (163). E. hirtipennis has also been reported from Hawaii and Fiji in the Pacific region (163).

Another flea beetle commonly found on tobacco is the congeneric $E$. fasciata (Blatchley) the southern tobacco flea beetle. This beetle occurs widely in Central America, the Caribbean, and extending as far south as Argentina. In the United States, its distribution is largely limited to the Gulf Coast, from Florida to Texas. The biology and host range of the southern tobacco flea beetle appears nearly identical to that of tobacco flea beetle.

\section{Plant hosts}

Tobacco flea beetle will feed on most cultivated and wild plant species in the family Solanaceae. However, the insect appears to prefer $N$. tabacum and S. tuberosum among cultivated plants and $D$. stramonium and Physalis pubescen among wild food plants.

Tobacco flea beetles reportedly will also feed on plants other than those in the family Solanaceae, but feeding on non-solanaceous plants appears very limited and serves as temporary food sources until more desirable plants are available (164). Non-solanaceous plants that have been associated with E. hirtipennis include Amaranthus spp., Beta vulgari (Amaranthaceae), Asclepias tuberosa (Apocynaceae), Arctium lappa, Ambrosia trifida, Xanthium strumarium, Erechtites hieraciifolius, Pseudognaphalium obtusifolium, Solidago juncea (Asteraceae), Campsis radicans (Bignoniaceae), Brassica spp. (Brassicaceae), Celtis sp. (Cannabaceae), Calystegia sepium, Ipomoea batatas, I. mauritiana (Convolvulaceae), Glycine max, Lespedeza spp., Phaseolus vulgaris, Pueraria montana, Vigna unguiculata (Fabaceae), Abutilon theophrasti (Malvaceae), Passiflora incarnate (Passifloraceae), Phytolacca americana (Phytolaccaceae), Zea mays (Poaceae), and Rubus spp. (Rosaceae).

\section{Classification and description}

Epitrix is a genus of flea beetles in the family Chrysomelidae, which are known as "leaf beetles". Chrysomelidae are characterized by not having their fron prolonged into a beak; with some exception (e.g., Bruchidae), the abdomen usually completely covered with elytra; filiform antennae, and not inserted into a deep groove by the eyes; segment two of the antennae is usually one-half the length of segment 3; and the front, mid, and hind tarsi are foursegmented.

Epitrix is placed in the tribe Alticini, a part of the subfamily Galerucinae. Most adult Galerucinae have their antennae inserted on the forehead, so close together that the distance between them is equal or less than the length of segment 1 of the antennae. The hind femur of most Alticini is large and strong, which enables the insect to jump like a flea when disturbed, thus the name "flea" beetles.

A detailed description of the genus Epitrix was given by DECZYNSKI(165). The genus consists of minute flea beetles (usually less than $3 \mathrm{~mm}$ ) most recognizable by their distinctive elytra with punctures arranged into striae; long setae arranged in rows, one or two rows between striae. The antennae are filiform and 11-segmented, with the scape larger than the second segment; segment 7-11 larger than 2-6; apical segment with concavity on lateral side of apex. The hind femora are greatly enlarged; tibia is approximately as long as femora and flattened laterally; hind tibia with single spine on apex; tarsi 4-4-4, with tarsal segment 3 bilobed; all tarsi with setae on underside; first metatarsomere approximately as long as the rest combined; tarsal claws divergent, simple.

Adult E. hirtipennis (Figure 12) is about $1.5-2 \mathrm{~mm}$ in length, oblong ovate in shape, and with subparallel sides. The elytra are reddish-brown, often shiny, and marked with a distinct dark transverse band along the dividing line. The head is moderately chitinous, and the first thoracic segment and last anal segment are slight chitinized. The antennae have 12 segments and are pale yellowish-brown in color. The outer four segments of the antennae are darker than the remaining eight. The legs are similar in color as the antennae, but with hind femora slightly darker. The thorax is 


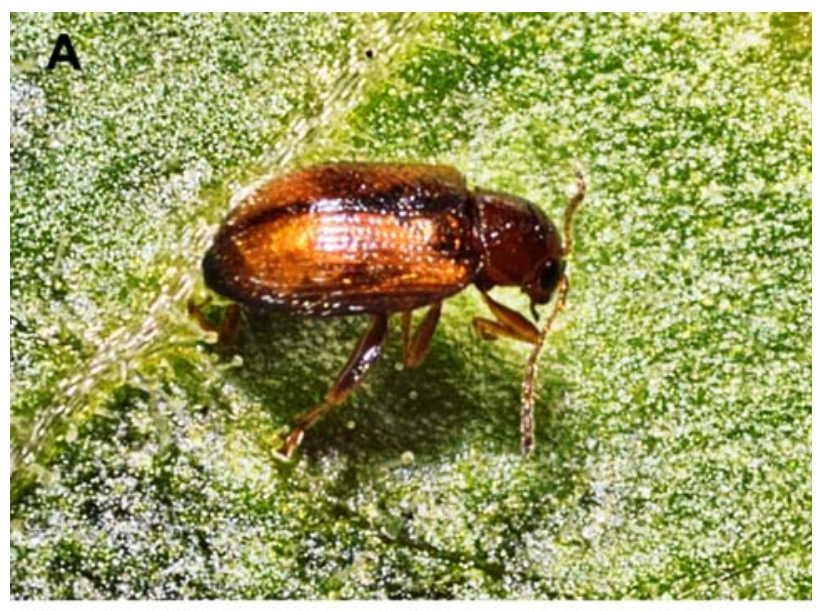

B

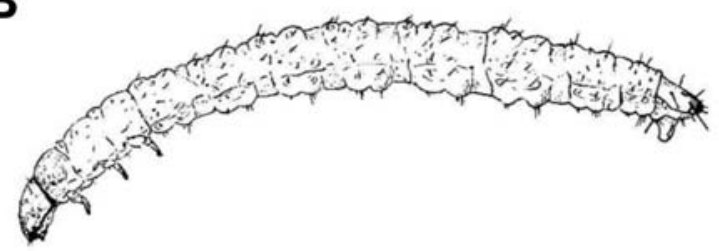

Figure 12. The tobacco flea beetle, Epitrix hirtipennis (A) adult (photograph by Peter Edde) and (B) larva (USDA, with permission).

convex and glossy brown, and it is about twice as wide as it is long. Pronotum is slightly transverse; evenly weakly convex; densely covered with small distinct punctures separated by approximately their diameter. The elytra have ten distinct striae, or a slight ridge, one ending at the basal one-third, and seven to nine interrupted by weak humeral callosities. The elytra bear one row of setae between elytral striae. The compound eyes are distinct.

\section{Damage}

The natural habitat of the Epitrix species larvae is subterranean. They feed on the small roots of tobacco plants and the underground part of the stem. Injury to tobacco may be noticed during the period from transplanting to 4 weeks afterward. Tobacco flea beetle eggs are laid at or near the roots of the plant, and the young larvae enter the soil to feed and tunnel in the roots, particularly the rootlets of newly set plants. This attack injures and discolors the plant base, resulting in wilting and a weakened condition that it stunts the plant and may cause it to die. The older larva girdles the plant roots or gnaws completely through them, severing the root from the plant. Because the larvae are rarely seen under field conditions, this type of injury is generally overlooked.

The major plant damage is caused by the adult flea beetles. The beetles eat many circular holes from about the size of a pinhead to about $5 \mathrm{~mm}$ in diameter through the leaves of the tobacco plant, which look like "shot holes" (Figure 13). The holes made by the adult beetle may also provide an entrance for fungus and bacterial diseases. When the crop is cured, it is poor and thin, and often full of small holes. As the insect continues feeding, these small holes increase in size. Under heavy infestation, the leaves become badly damaged and are ragged in appearance (Figure 13).

\section{Biology and ecology}

The biology of the tobacco flea beetle was described by JEWETT (166), GUi (167), DOMINICK (168), METCALF and UNDERHILL (164), and CHAMBERLIN et al. (169). Rearing techniques for the insect have been described [e.g., JEWETT (166); DOMINICK (168)].

The beetle overwinters in the adult stage. Overwintering sites include under leaves and other debris in the edges of fields or in woods next to the tobacco fields, where the insects had occurred during the summer. In Virginia, USA, some beetles begin to hibernate in late September, and by the end of October most beetles have gone into hibernation (168). The insects hibernate under trash on the ground in the field, especially in the curled leaves of the cut stalks left on the ground after harvest. Tobacco stumps of the previous season also appear to be a favorable overwintering site, more than the debris around the stumps. The tobacco flea beetle adults emerge from hibernation in the field in midMarch and continue to emerge until the last week in July, depending on the location $(167,168)$. Upon emergence from hibernation, the beetles at once migrate to available food plants, mate, and lay eggs.

Very little is known about the mating behavior or chemical communication in the tobacco flea beetle. However, ZILKOWSKI et al. (170) showed that $(2 E, 4 Z, 6 Z)-2,4,6$-nonatriena, geometrical isomers of 2,4,6-nonatriena, in volatile

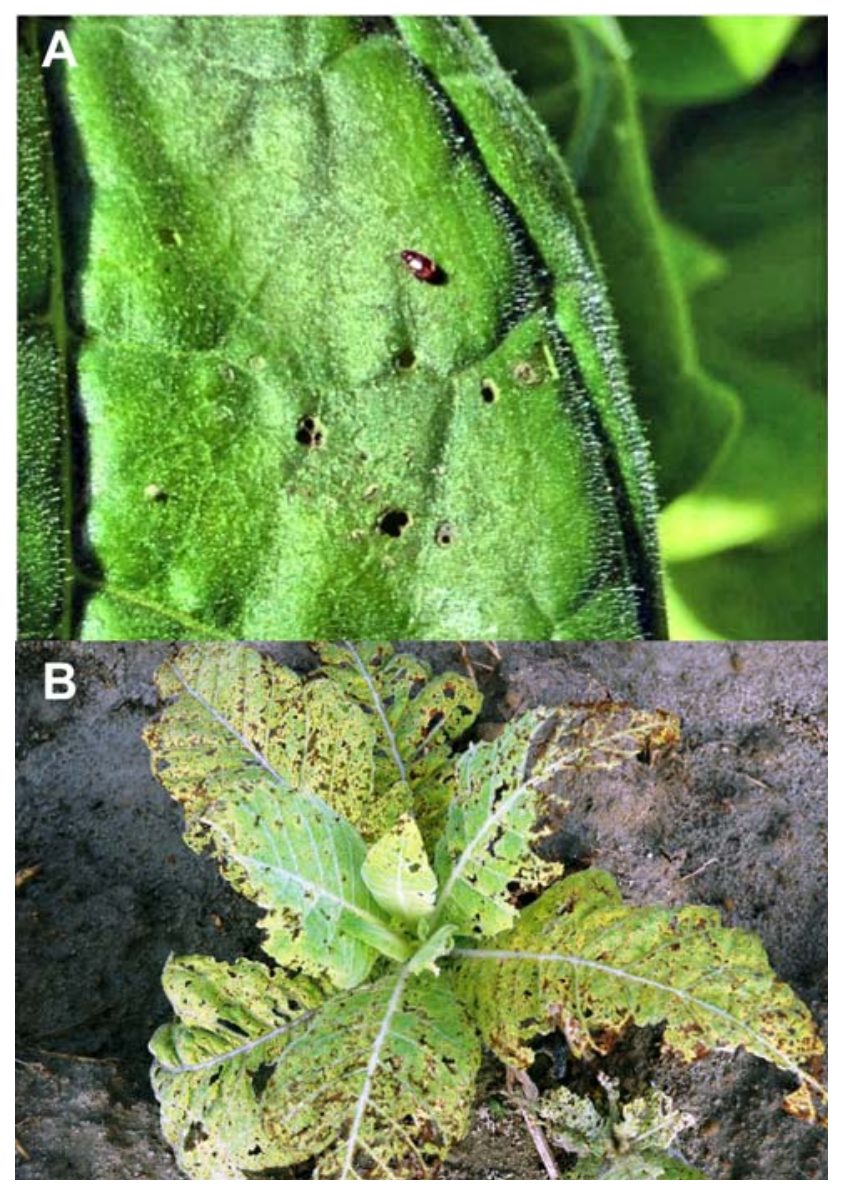

Figure 13. Tobacco leaf showing (A) "shot hole" and (B) ragged injury caused by flea beetle feeding (photographs by Peter Edde). 
collections from male E. hirtipennis were attractive to females of the same species, thus supporting a pheromonal role for the compounds in E. hirtipennis. The compound was not detected in female beetles of the species.

The first eggs are deposited by the beetles 14 days after emergence from hibernation (168). The preoviposition periods of later broods tend to be shorter. Tobacco flea beetle eggs are elongate oval, slightly pointed at one end and broadly rounded at the other. The eggs are $0.362-0.483 \mathrm{~mm}$ (average $0.41 \mathrm{~mm}$ ) long and $0.164-0.259 \mathrm{~mm}$ (average $0.18 \mathrm{~mm})$ in diameter $(164,169)$. When freshly deposited, the eggs are translucent and pearly white, but gradually change to dull gray and to tan as they age. There are slight but distinct reticulations on the chorion $(164,169)$. The eggs of the tobacco flea beetle are often deposited in cracks or small depressions in the soil near the base of its food plant (168) or in moist soil at depths of $1.3-5 \mathrm{~cm}$ (167). In newly set tobacco, the eggs are deposited on the soil near the base of the stalk. DomINICK (168) noted that the eggs are generally deposited pointing in a downward direction, with the broader end being visible.

A female of the overwintering brood deposits an average of 154 eggs during an oviposition period of about 55 days. Later broods tend to lay fewer eggs, and the oviposition period is shorter. Most of the eggs hatch in about a week under field conditions in summer months. Environmental conditions influence the length of the incubation period, thus early spring and late season, the incubation period may extend to 9 days or more (164). DOMINICK (168) reported that the eggs required up to 22 days before hatching in early spring, whereas during midsummer, the eggs hatched in 4-7 days.

The newly hatched larva is a long, slender, white grub with body segments of about equal size, except for the last segment, which is smaller (164). The larva (Figure 12) measures about $0.50-0.75 \mathrm{~mm}$ long and $0.12-0.15 \mathrm{~mm}$ wide. It is slender, milky white, and 12-segmented; with three pairs of short, five-jointed legs on the thorax and a proleg on the last segment. The head is without ocelli, yellowish-brown in color, elongate, and slightly flattened dorsoventrally. Each lobe of the epicranium is pointed posteriorly and separated by a conspicuous medial suture that extends from the dorsal margin of the epicranium, through the middle of the frons, to the margin of the clypeus. Two diverging grooves or sulci extend from the middle of the epicranium outward and downward nearly to the base of the vestigial antennae. The sulci gradually become less conspicuous as they approach the antennae. There are seven hairs on each lobe of the epicranium and the gena above and posterior to the diverging sulci. There are four hairs on each half of the frons. The labrum is anteriorly rounded, with a row of short setae, two on each side. The larva is $4.31-4.78 \mathrm{~mm}$ long when fully developed.

The larvae are subterranean in habit. The average length of the larval stage is about 14-16 days under summer conditions $(164,169)$, and may last up to 44 days in the early spring (168). They pass through three instars before pupating. The average length of the first, second, and third instars are 5.48, 3.67, and 6.70 days, respectively (169). However, the length of the larval stage is greatly influenced by environmental conditions, and it could be as long as 41 days in early spring in Florida, USA (169). The length of the pre-pupal period ranged 1-8 days (168).

Pupation occurs in the soil. The last instar larva forms a small oval-shaped cell in the soil, where it pupates. Newly transformed pupae are whitish in color and about same size as the adult. CHAMBERLIN et al. (169) noted that the average length of the pupal stage during the summer months in Florida, USA is about 5 days. In Virginia, USA, the period ranged from a minimum of 13 days in the spring to a minimum of 3 days in midsummer. In the fall, the pupal period ranged from of 10 to 16 days.

The length of the time needed from deposition of the egg to the emergence of the adult is about 1 month under summer conditions, but could be as long as 46 days in early spring or 53 days in fall (168). Newly emerged tobacco flea beetles first feed on the lower leaves near the ground. After a few days, they spread to other parts of the plants.

Adult tobacco flea beetles can live for about 7-8 weeks, resulting in overlapping generations and almost continuous egg production. There are two to five generations of tobacco flea beetles per year, depending on location. Detailed life-history studies by DOMINICK (168) show that each year in Virginia, USA, there are four complete generations of the tobacco flea beetle. First-generation adults begin appearing in early June; those of the second generation around mid-July; third generation about midAugust; and those of the fourth generation in early October. One complete generation and a partial second generation is characteristic of the species in Wooster, Colorado, USA (167). As showed above, the tobacco flea beetle's lifespan varies during the cropping season and has been estimated by DoMINICK (168) as follows: overwintering brood, 14 days; first brood, 7.5 days; second brood, 7 days; third brood, 9-11 days. Females of the fourth generation typically do not lay eggs before going into hibernation.

\section{Management}

\section{- Scouting technique}

Regular scouting should be carried out 1-4 weeks after transplanting to decide whether remedial control is necessary (171). Early in the season, tobacco flea beetle adults may be present on the entire plant, feeding on the surfaces of upper and lower leaves. Later in the season, the pest is most common in the lower one-third of the plant, near the stalk. When scouting the field for tobacco flea beetles, look for the characteristic shot-hole feeding damage, and then count the beetles on 20 plants (two per field-sample location) (172). Adult flea beetles can also be sampled using the standard ( $38 \mathrm{~cm}$ diameter) sweep net. The adults are very active and can jump, so it is best to scout for them in the morning, when temperatures are cool, and they are less active.

DUKE and LAMPERT (173) described a method for estimating the population of larvae, pupae, and emerging adult tobacco flea beetles in a tobacco field. Briefly, soil cores $10 \mathrm{~cm}$ in diameter by $15 \mathrm{~cm}$ deep are taken from the row center, directly next to a randomly selected plant. The larvae are mobile and can be readily retrieved from the soil samples with Berlese funnels. The pupae are an immobile stage. Thus, they are best retrieved from the soil samples 
using the flotation method, or their numbers may be estimated by visual examination. The soil samples can be held for adult emergence, or traps can be used to capture the adults as they emerge from the soil. The authors recommended 50,12, and 30 soil core samples for the larvae, pupae, and adult stages, respectively.

However, the sampling method described by DUKE and LAMPERT (173) is useful for collectors. The method appears not practical in applied entomology because it is too time consuming and needs special equipment to be helpful for a grower. In addition, most growers already use a systemic insecticide that gives effective control.

\section{- Action threshold}

Treatment threshold for flea beetle control on newly set tobacco $(<2$ weeks old $)$ is an average of four beetles per plant, and eight to ten beetles per plant on 2-4-week-old plants $(27,107,172)$. As the plants become larger, they can tolerate higher flea-beetle densities. The recommendation for plants 4 weeks old and older is 60 or more beetles per plant.

\section{- Non-chemical}

Cultural control methods include the following strategies:

- Remove and destroy solanaceous weeds throughout the season to destroy breeding sites for tobacco flea beetles and other tobacco insect pests.

- Destroy stalks and plow up the roots at once after harvest is completed.

- Avoid crop rotation practices that involve growing tobacco where other solanaceous plants had been grown. The value of crop rotation as a pest management strategy is limited, as many adults overwinter inside and outside of the cropped areas, and the insect is capable of long-range flight.

- Avoid growing solanaceous crops next to tobacco fields unless these crops receive the same pest management practices as recommended for tobacco.

- Nitrogen-deficient tobacco is likely to be more susceptible to flea-beetle damage after topping (107). Adequate fertilization helps promote vigorous plant growth, enabling them to withstand flea beetle attack.

- In tobacco plant beds, soil fumigation before seedling will help limit populations of flea beetles and other soilborne tobacco insect pests.

- Flea beetles prefer bright and warm and dry conditions. Irrigation will also stimulate the young crops so that they will outgrow flea damage more quickly.

- Flea beetle damage may also be limited by scheduling plantings so that seedlings are emerging during periods of low flea beetle activity.

\section{- Natural enemies}

CHAMBERLiN et al. (169) and DOMINICK (168) noted that tobacco flea beetles have natural enemies that prey on the insect. They include the following insects and organisms:

- Insects - One important natural enemy of the tobacco flea beetle is the fly Hypostena barbata (Diptera: Tachinidae), which develops within the abdomen of the adult beetle. The beetle is also preyed upon, to a limited extent, by general predators such as bigeyed bugs Geocoris punctipes (Hemiptera: Lygaeidae) and damsel bugs Nabis spp. (Nabidae).

- Parasites - The principal parasitoids of the adult stage of the beetle and related Epitrix species seem to be Microctonus epitricis, M. vittatae, Microctonus sp. (Hymenoptera: Braconidae). These braconids often escape through an aperture made at the anal orifice of the parasitized beetle (174).

- Nematodes - Howardula dominicki (Nematoda: Allantonematidae) parasitizes up to $70 \%$ of the tobacco flea beetle larvae and $50 \%$ of the adults (175). Adult females infected by the nematode had reduced fecundity, as reported by ELSEY and PITTS (175), who described the biology of this nematode. Other soil dwelling nematodes such as Steinernema spp. (Steinernematidae) and Heterorhabditis spp. (Heterorhabditidae) can attack the flea beetle larvae, reducing the later adult populations (176).

- Fungi - White muscadine, a disease caused by the fungus Beauveria bassiana (Fungi: Clavicipitaceae), can affect both larvae and adults of many insects, including tobacco flea beetles (176).

\section{- Chemical}

Neonicotinoid insecticides (imidacloprid and thiamethoxam) applied as greenhouse tray drench or transplant water treatments give excellent early-season control of flea beetles. Cyantraniliprole can be applied in the same manner. Effective remedial treatments include foliar applications of acetamiprid, acephate, bifenthrin, lambdacyhalothrin, imidacloprid, thiamethoxam and several combinations.

THRIPS - Tobacco thrips (Frankliniella fusca Hinds, 1902) - Western flower thrips (Frankliniella occidentalis Pergande, 1895)

\section{Taxonomic position}

Order: Thysanoptera

Family: Thripidae

\section{Common names}

See the common names of the respective species.

Damaging stages

Adult and nymph

\section{Distribution}

See the distribution of the respective species.

\section{Plant hosts}

The tobacco thrips (Frankliniella fusca) is known to attack a wide range of plant species. WATSON (177) listed about 20 plant species known as hosts for this species. 
ChAMBERLin et al. (178) listed 24 plant species as winter and spring hosts of $F$. fusca in Georgia, USA. Among the principal hosts listed for the insect are N. tabacum, Xanthium strumarium, Avena sativa, Capsella bursa-pastoris, Gossypium spp., Brassica sp., Allum cepa, Trifolium spp., Medicago spp., and several species of grasses (Poaceae) (177-181).

The western flower thrips ( $F$. occidentalis) is polyphagous and has been collected from plants of about every order of the Spermatophyta in several countries. For example, BRYAN and SMITH (182) recorded the species on 139 plant species in 45 families in California, USA. DIMITROV and VELICKOVA (183) collected $F$. occidentalis from 64 plant species belonging to 25 families in Bulgaria. YUDIN et al. (184) identified 48 plant species in 13 families as hosts for $F$. occidentalis on the island of Maui, Hawaii, USA. In addition, CHAMBERLIN et al. (178) listed 44 plant species in about 20 families in Georgia, USA as host plants in winter and spring.

\section{Classification and description}

Adults of the Thysanoptera, or thrips, (Figure 14) are elongate, slender, mahogany brown to black insects. They are small insects, under $4 \mathrm{~mm}$ in length. Because of their small size, microscopic examination is often needed for identification. The body is cylindrical or spindle-shaped, with 6-10 segmented antennae. Tarsi 1-2 are segmented, with eversible adhesive bladders apically. Adult thrips may be winged or wingless. The wings, when present, consist of two pairs of a slender, sclerified or rod-like axis bearing a dense fringe of long hairs (macropterous). The wings are folded along the body when the insect is at rest. However, some thrips species have their wings greatly reduced (brachypterous). Immature thrips are like the adults in appearance, but they are smaller, always wingless, and usually lighter in color. Thrips (adult and immature) have piercing and sucking mouthparts. Most species are plant feeders. They feed by rasping the leaf surfaces, sheaths, and heads with their mouth stylets and sucking up the sap which flows from the injured area. Some species are predators of other arthropods such as mites, other thrips, and various small insects.

The order Thysanoptera is divided into two suborders, Terebrantia and Tubulifera. Tubulifera contains a single family, the Phlaeothripidae. There are 13 families in the Terebrantia; 8 of these are Aeolothripidae, Heterothripidae, Fauriellidae, Melanthripidae, Merothripide, Stenurothripidae, Thripidae, and Uzelothripidae (185-187). The remaining five are known only from fossil records (187). Adults in the suborder Tubulifera can be easily recognized by the fact that females are without ovipositor, and the last abdominal segment in both sexes closed below, usually tubular (177). Females of Terebrantia have a saw-like ovipositor (188). The last abdominal segment is rarely tubular in the female, often divided lengthwise along the ventral surface and usually conical; in the male, it is usually bluntly rounded, but never tubular (177).

The family Thripidae is grouped into four subfamilies, Dendrothripinae Priesner, 1925 (16 genera), Panchaetothripinae Bagnall, 1912, Sericothripinae Karny, 1921, and Thripinae. According to Mound and KIBBY (185), mem-

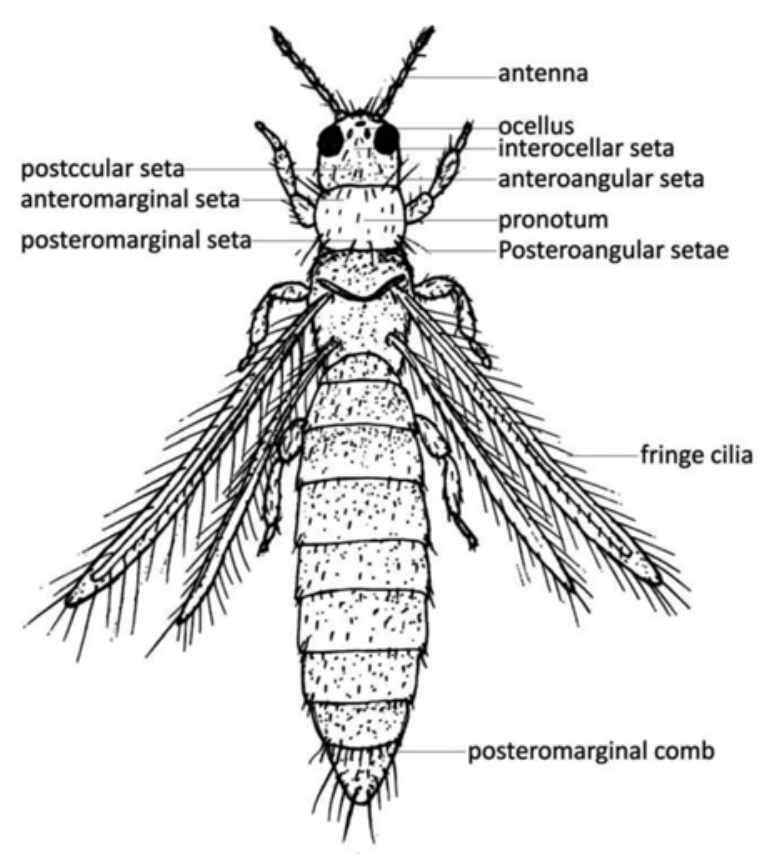

Figure 14. Stylized drawing of a Frankliniella thrips showing morphological characteristics [modified from TUTTLE (266)]. Most Frankliniella species are less than $2 \mathrm{~mm}$ long when fully mature.

bers of the family Thripidae can be distinguished from other thrips by the following characteristics: ovipositor is saw-like and curves downward; the wings are narrow with two veins; and there are six to ten antennal segments, with antennomere III and IV with stiletto-like forked sense cones. A key to separate the subfamilies of Thripidae was provided by MASUMOTO (189). Thripinae is the largest of the four subfamilies in the family Thripidae, containing about 1660 species in 230 genera (190). MASUMOTO (189) and MIRAB-BALOU et al. (191) provided a key to the genera of Thripinae.

The genus Frankliniella is of the subfamily Thripinae. SAKIMURA and O'NeILL (192) provided a detailed description of this genus. There are about 230 species in this genus most with ctenidia on each side of abdominal terga $\mathrm{V}$ (rarely IV)-VIII, which on tergite VIII extends laterally before the spiracles $(192,193)$. The pronotum is rectangular and usually has five pairs of well-developed hairs or setae (anteromarginals, anteroangulars, and posteromarginals each one pair, posteroangulars two pairs) (189). All have a pair of setae (pair III) that arises between or in front of posterior ocelli (194). A complete row of setae is present on both veins of the forewing (195). The antennae are usually eight-segmented, segments III and IV each with a forked sensorium (193). Segment VIII of the antenna is longer than segment VII. The front tarsus has no tooth; Tarsi 2-segmented. SAKIMURA and O'NEILL (192) reported that seta pair ii is reduced on tergites V-VII, and, as in many other thripines, seta pair iii is reduced on tergites VI-VIII. The workers noted that Frankliniella can be distinguished from most other ctenidia-bearing genera of Thripina by the reduction of tergal seta pair ii and the position of the ctenidia on tergite VIII. 
Tobacco Thrips — Frankliniella fusca Hinds, 1902

Synonyms

Euthrips fuscus Hinds, 1902

Euthrips nicotianae Hinds, 1905

Scirtothrips owreyi Watson, 1924

\section{Distribution}

Frankliniella fusca, the tobacco thrips, is probably native to southern United States, but its distribution now extends throughout the continental United States and Canada, east of the Rocky Mountains in the north, and into Puerto Rico, Martinique, and Mexico in the south (195). F. fusca has also been recorded infesting bulbs of wild daffodil or Lent lily Narcissus pseudonarcissus (Asparagales: Amaryllidaceae) in Honshu, mainland Japan (196).

\section{Description}

HINDS (179) and HoDDLE et al. (195) provided a detailed description of $F$. fusca. JOHANSEN (197) provided a key to separate $F$. fusca from the morphologically similar $F$. pallida (Uzel) and F. schultzei (Trybom). The average body length of the adult is about $1.05 \mathrm{~mm}(0.95-1.13 \mathrm{~mm})$. The general color of head and thorax is light brown or tawny yellow-brown. In dark specimens, the abdomen is blackish brown; in light specimens, the general color is yellowish brown.

The head is about 1.5 times as wide as it is long, often slightly retracted under the anterior margin of prothorax. The antennae are inserted a little below the margin, about three times as long as the dorsal length of head. The first antennal segment is rounded, one-third wider than long; the second is cup-shaped; the third through sixth segments vary in thickness, with the third through fifth being a bit clavate and the sixth being cylindrical-ovate (198). The third antennal segment is yellowish; the fourth and fifth segments are light grayish brown, and yellowish at the base. The pedicel of the third antennal segment has margins that are parallel to softly rounded (194).

Adults (both sexes) can be either fully winged (macropterous) or have short wings that are shorter than the thorax width (micropterous) (194). The short-winged form typically occurs during some season of the year. For example, CHAMBERLIN et al. (178) reported that the adult tobacco thrips are predominantly micropterous during the late fall and early spring in Georgia, USA. The wing lobe is shorter than width of thorax. Adults of both sexes lack a posteromarginal comb on abdominal segment VIII. The forewing is mostly mahogany brown, with two complete rows of veinal setae. Postocular spines appear weak and inconspicuous (179). On the wings, the costa bears 19-24 spines; the fore vein, 13-18; and the hind vein 10-12 (179, 199).

Males are smaller and paler than females. Discal setae are absent in sternites III-VII of females. Male abdominal sternites III-VII are with pore plates, which are transverse and narrow to broadly oval (195).
Western Flower Thrips - Frankliniella occidentalis Pergande, 1895

Synonyms

Euthrips occidentalis Pergande, 1895

Euthrips tritici californicus Moulton, 1911

Euthrips helianthi Moulton, 1911

Frankliniella tritici var. moultoni Hood, 1914

Frankliniella nubila Treherne, 1924

Frankliniella tritici maculata Priesner, 1925

Frankliniella claripennis Morgan, 1925

Frankliniella canadensis Morgan, 1925

Frankliniella trehernei Morgan, 1925

Frankliniella occidentalis brunnescens Priesner, 1932

Frankliniella occidentalis dubia Priesner, 1932

Frankliniella venusta Moulton, 1936

Frankliniella conspicua Moulton, 1936

Frankliniella chrysanthemi Kurosawa, 1941

Frankliniella dahliae Moulton, 1948

Frankliniella dianthi Moulton, 1948

Frankliniella syringae Moulton, 1948

Frankliniella umbrosa Moulton, 1948

\section{Distribution}

Frankliniella occidentalis is native to western North America. It was first reported by PERGANDE (200) in California on apricot and potato leaves, orange flowers, and various weeds but has become established throughout North America and in many countries of Europe, Asia, South America, Africa, and Australia (201).

\section{Description}

Adults of both sexes of $F$. occidentalis are fully winged with long fringes of cilia, which is typical of most Thysanoptera. Body and legs are variable in color. Wild populations of the species often occur as three distinct morphs. These color morphs are termed dark-brown, yellow, and intermediate yellow with a dark longitudinal band along the dorsum of the thorax and the abdomen $(195,202)$. The widespread pest strain is usually the intermediate form (195).

HODDLE et al. (195) and CLUEVER et al. (202) describe a combination of distinguishing features that may be used to differentiate $F$. occidentalis from its congeners. Members of the genus have a smooth antennal pedicel, with spines arising from the second antennal segment that are not exceptionally heavy. Similar to its congeners, $F$. occidentalis has three pairs of ocellar setae present, but pair III is longer than the distance between the external margins of hind ocelli, arising on anterior margins of triangle; postocular setae pair I present, pair IV longer than the distance between the hind ocelli. In addition, four small setae are present on the anterior margin of the prothorax between the major antemarginal setae.

Adults of both sexes of $F$. occidentalis are similar in appearance. The female is $1.0 \mathrm{~mm}$ long and the male is slightly smaller, averaging $0.7 \mathrm{~mm}$, and paler (203). 
Females have a complete and well-developed posteromarginal comb on abdominal segment VIII, but it is lacking in the males. There are no discal setae on sternites III-VII of females, while sternites III-VII of males have transverse pore plates.

Although the western flower thrips is a major crop pest, the insect occasionally is beneficial to growers in other agroecosystems. For example they sometimes feed on spider mites, a serious pest of young cotton seedlings (204).

\section{Damage}

The mouthparts of Thysanoptera and the feeding habits of some species of thrips have been described [e.g., BORDEN (205); PETERSON (206)]. Both the adults and larvae have rasping/sucking mouthparts and feed in an analogous manner by piercing plant epidermal cells with their mouthparts and sucking out the contents. Thrips damage may be more severe in areas prone to cool, wet conditions, which enable thrips to feed several times on the same tissue in slow-growing crops. The insect is also likely to cause considerable damage under dry conditions.

Thrips are early-season pests of crops in several countries $(207,208)$. In tobacco, the first signs of the presence of the insect are silvery outlines traced around, and parallel to, the midrib and vein of the lower leaves (209). If heavy infestations persist unchecked, feeding activities may lower plant vitality, plants can become stunted, chlorotic, and seedling stands may be reduced. LACROIX (209) noted that the injury is more pronounced when the leaves are cured, for then, the silvery effect contrasts strongly with the brown, dry tissue. As a result, the market value of affected tobacco is significantly reduced.

Direct damage due to thrips attack can be less important in respect to indirect damages, especially the transmission of diseases. Thrips cause indirect damage by transmitting viruses or as passive carriers of fungal and bacterial spores. For example, $F$. occidentalis and $F$. fusca are major vectors for tomato spotted wilt virus or TSWV (Bunyaviridae: Tospovirus) (210). TSWV causes serious diseases of many economically important plants, including tobacco, tomatoes, peppers, peanuts, and many ornamental species. SHERWOOD et al. (211) described the disease cycle and epidemiology of TSWV. TSWV overwinters in several weed species, including buttercup, dandelion, sowthistle, and many other winter annuals, which are the primary source of infection in tobacco. Thrips get the virus by feeding on infected plants or weeds. Symptoms of TSWV differ among hosts and can be variable in a single host species. Stunting is a common symptom of TSWV infection, and it is more severe when young plants are infected (201). Once a tobacco plant is infected with TSWV, particularly shortly after transplanting, it will soon die, leading to stand reductions in tobacco field. F. fusca is also known as a vector of Pantoea ananatis (Enterobacteriaceae: Pantoea), a bacterial disease that infects both monocotyledonous and dicotyledonous plants. The symptoms of the disease are diverse depending on the host infected and include leaf blotches and spots, die-back, and stalk-, fruit-, and bulb rot (212).

\section{Biology and ecology}

HOOKER (199), EDDY and LivingSTONE (180), and WATTS (203) studied the life history and habits of $F$. fusca on tobacco or cotton. Similar information for F. occidentalis have been provided by BRYAN (213) and REITZ $(214,215)$. Apart from a few minor details, the life cycles of these thrips are similar to one another, and they are similar to the general life cycles of terebrantian thrips. Most species of thrips overwinter as adults around roots, or at the base of, host plants $(180,181,216)$. NEWSOM et al. (181) noted that thrips can be found throughout the year in areas with mild winters. The tobacco thrips, for example, become active in spring, and may be observed in southern United States in April, feeding upon common cocklebur (Xanthium strumarium), the primary weed host. From the weed they migrate to the tobacco plants, when the latter are transplanted.

A thrips' life cycle consists of the egg, two active feeding larval or nymphal stages, pre-pupa, pupa, and adult. Neither the pre-pupa nor the pupa feeds. Although thrips do not undergo a complete metamorphosis, the terms larva and pupa are often generally used among Thysanoptera researchers. Thrips populations may consist entirely of females that do not require mating in order to lay fertile eggs, a phenomenon described as parthenogenesis. Unmated females give rise to a male progeny. Other populations may include both sexes, and mating may occur. To be able to produce female offspring, $F$. fusca and $F$. tritici females must mate (217). Where mating is necessary, the thrips mate and lay eggs as soon as the adults emerge. The duration of mating is short, lasting about $1.5 \mathrm{~min}$ (218). Most terebrantian females use their saw-like ovipositors to make an incision in plant tissues, and then insert their eggs into the incision. In tobacco, the eggs are usually deposited in tissues of the stem and leaves. Frankliniella females can lay up to 160 eggs or more in a lifetime. REITZ (214) reported that the largest number of eggs laid in 1 day was 18 for $F$. occidentalis and 17 for $F$. tritici. Eggs are pale in color, cylindrically shaped, with smooth chorion, and almost kidney-shaped.

The optimum temperature for development is around $25-30{ }^{\circ} \mathrm{C}$ (215). The lower threshold for development is $\leq 14{ }^{\circ} \mathrm{C}$ and the upper threshold $\geq 30{ }^{\circ} \mathrm{C}$. At optimal temperatures, the eggs hatch in about 3-4 days. On hatching, the larvae feed on the lower surface of tobacco leaves, but as they reach the adult stage, they prefer the upper surface. As mentioned, there are two larval or nymphal stages. The stages are similar in appearance to the adults, but they have no wings. Adults and nymphs are often found together feeding on similar host resources. The nymphs, when newly hatched, are translucent to white in color, but they become a light yellow after about 2-3 days as they feed. The nymphs soon molt into the second nymphal stage, an orange-colored form. This second nymphal stage lasts for about 3-4 days, then transforms to the pre-pupal stage. The duration of the prepupal stage is very short, often lasting less than 1 day. The prepupa is like the larva in color and general shape, but the prepupa differs from the larva in some easily observable features. The prepupa has short wing pads that reach to about the second abdominal segment, and its antennae are slightly shorter (217). The 
pre-pupal stage transforms into a pupa, and pupates in the soil in cells lined with silken threads. Working with another terebrantian thrips, Megalurothrips usitatus (Bagnall), CHANG (219) found that about $75 \%$ of the mature larvae of thrips pupated $10 \mathrm{~mm}$ under the soil surface when they were placed in sandy loam soils. The pupa is similar to the prepupa in color and general shape. It differs markedly from the prepupa in having the antennae fastened throughout their length to the upper surface of the head (217). As shown earlier, the prepupa and or pupal stages are capable of some movement, but there is no feeding in either of these stages. The entire larval development period is about 7-10 days. The duration of the pupal stage is about 4-7 days, and adults emerge and initiate another generation.

The life cycle is completed in about 10-13 days under summer field conditions. PFRIMMER (217) estimated that, at $22-23{ }^{\circ} \mathrm{C}$, the entire life cycle, from egg to adult, of a female $F$. tritici, F. fusca, and Thrips tabaci is about 17.8, 20.5, and 21.5 days, respectively. An inverse relationship exists between development time and temperature for thrips, as is typical of insects. For example, on peanut, egg-to-adult duration decreased from 24 days at $20^{\circ} \mathrm{C}$ to 11 days at $35^{\circ} \mathrm{C}$ and from 19 days at $20{ }^{\circ} \mathrm{C}$ to 14 days at $25^{\circ} \mathrm{C}$, respectively for $F$. fusca and $F$. occidentalis (220). The upper development threshold estimated for $F$. occidentalis is $30^{\circ} \mathrm{C}$. The lower development threshold estimated for $F$. fusca was $10.5{ }^{\circ} \mathrm{C}$ and $6.5{ }^{\circ} \mathrm{C}$ for $F$. occidentalis (220). REITZ (214) reported that $F$. occidentalis and $F$. tritici showed similar patterns in development and reproduction at $28.0^{\circ} \mathrm{C}$. However, the median development time for immature $F$. tritici was 1 day faster than for $F$. occidentalis.

The longevity of most terebrantian females is greater than that of the males. When food is provided, adult male and female thrips can live up to about 8 and 22 days, respectively. Longevity of adult males and females under complete starvation is about 2-4 days. After the tobacco is harvested, thrips live on weeds in the field until winter temperatures drive them into hibernation.

\section{Management}

\section{- Scouting technique}

Information on a sampling plan for thrips on tobacco is not readily available. However, studies on other agronomic crops, such as tomato and cotton, showed that four different sampling techniques are often used in collecting thrips for population counts: with an aspirator, the beat-cup, vial flower collecting, and an insect vacuum device. Flower sampling may not be of importance in tobaccos because the plants are topped to prevent flowering, except in cases where the plants are grown for seed production. The most commonly used and accurate of these methods are the aspirator and the beat-cup methods (221)

Adults can be trapped using yellow sticky cards placed in and on the perimeters of crop fields to monitor thrips presence or absence according to different plant hosts and seasonal changes.

\section{- Action threshold}

Information on a threshold for thrips control on tobacco is not readily available.

\section{- Non-chemical}

Management of thrips and TSWV include the following cultural tactics:

- Where available, use host plant resistance as part of the cropping system.

- Destroy volunteer crops and annual weeds in cultivated fields to reduce overwintering breeding sites for thrips.

- Maintain good soil fertility management practices, especially those that increase soil microbial activity, as this may reduce thrips attack.

- Carefully select crops in rotation to avoid planting thrips-susceptible crops following crops that are known to give good over-wintering sites for thrips.

- Use trap crops to take advantage of the inherent preference of thrips to feed on more attractive plants.

- Crops suffering from drought stress are more susceptible to thrips damage. Heavy irrigation, specifically sprinkler irrigation, or rainfall will help to dislodge thrips from plants, kill larvae, and suppress dispersal or destroy pupae in the soil by crusting or burying them in the soil.

\section{- Natural enemies}

A wide range of natural enemies attack thrips. The most important include the commercially available predators belonging to the genus Orius (Heteroptera: Anthocoridae). Both adults and nymphs of Orius feed on all stages of thrips by using their piercing-sucking beak to suck haemolymph from the bodies of their prey. All stages move fast and are attracted to flowers and to plants that have softbodied prey insects, such as thrips, mites, aphids, whiteflies, leafhoppers, many kinds of insect eggs, and tiny newly-hatched caterpillars.

Another group of commercially available predators are the predatory mites Neoseiulus spp., Transeus montdorensis (Phytoseiidae), and Hypoaspis spp. (Laelapidae). These mites attack eggs and larvae of other thrips and kill them before they can become adults. Mites also kill their prey by sucking out the body fluids. However, thrips is considered a secondary source of food for these mites, especially Neoseiulus as they prefer tetranychid mites as food. In addition to thrips, the mites may also feed on pollen in absence of primary prey.

There are also many naturally occurring beneficial organisms that may help to control thrips in the tobacco and related cropping systems. These include:

- Acari - Lasioseius floridensis (Ascidae), Abrolophus neobrevicollis (Erythraeidae), Cosmolaelaps jaboticabalensis, Gaeolaelaps aculeifer, Hypoaspis spp., Stratiolaelaps spp. (Laelapidae), Macrocheles robustulus (Macrochelidae), Amblydromalus limonicus, Amblyseius spp., Euseius spp., Iphiseius degenerans, Metaseiulus occidentalis, Phytoseiulus spp., Proprioseiopsis asetus, Typhlodromus pyri (Phytoseiidae) 
- Araneae - Xysticus kochi (Thomisidae)

- Bacteria - Chromobacterium subtsugae (Neisseriaceae)

- Coleoptera - Harmonia axyridis (Coccinellidae), Dalotia coriaria (Staphylinidae)

- Fungi - Neozygites parvispora (Entomophthorales), Beauveria bassiana, Isaria fumosorosea, Lecanicillium muscarium, Metarhizium flavoviride, Purpureocillium lilacinum, Torrubiella petchii (Hypocreales)

- Heteroptera - Anthocoris nemorum, Deraeocoris pallens, Dicyphus spp., Macrolophus spp., (Miridae), Geocoris spp. (Geocoridae)

- Hymenoptera - Ceranisus spp. (Eulophidae).

- Nematode - Thripinema nicklewoodi (Allantonematidae), Heterorhabditis spp. (Heterorhabditidae), Steinernema spp. (Steinernematidae)

- Thysanoptera - Franklinothrips vespiformis (Aeolothripida)

- Neuroptera - Chrysoperla carnea, spp., Mallada signata (Chrysopidae)

\section{- Chemical}

As previously discussed, thrips usually do not cause serious direct injury to tobacco. Their economic importance is due to role as vectors of TSWV, a major economic problem for tobacco growers in the United States, various Eastern European countries, and Greece. Economic damage has also been reported from some countries in Asia and Oceania. However, TSWV occurs with different severity in many tobacco-producing countries. In the United States, it has caused serious losses in Georgia and North Carolina in some years (up to 40\% stand loss in Georgia) (222).

Insecticides recommended for thrips control include: imidacloprid and thiamethoxam applied as greenhouse tray drench treatments and foliar applications of acephate, acetamiprid, imidacloprid, thiamethoxam, bifenthrin, spinosad, lambda-cyhalothrin, and cyfluthrin.

Foliar applications for thrips control are not effective for reducing TSWV after seeing the disease. In areas that experience losses to TSWV year after year, growers can reduce their losses by making greenhouse tray drench applications of imidacloprid or thiamethoxam before transplanting into the field $(70,223)$. For example, MCPHERSON et al. (223) showed that the application of imidacloprid and thiamethoxan applied in the transplant water or as a tray drench, were effective in reducing the early-season thrips populations and reducing the seasonal cumulative incidence of TSWV.

JAPANESE BEETLE — Popillia japonica Newman, 1841

\section{Taxonomic position}

Order: Coleoptera

Family: Scarabaeidae

\section{Common name}

Japanese beetle

Synonym

Popillia plicatipennis Burmeister, 1844

\section{Damaging stages}

Adult and larva

\section{Distribution}

Popillia japonica originates from Asia, where it is native in northern China, Japan, and the Far East of Russia, where it was regarded as a minor agricultural pest. The beetle was first detected in the United States in 1916 when inspectors of the New Jersey State Department of Agriculture discovered it in a nursery near the city of Riverton. The beetle was presumably accidentally introduced into the country in the larval stage in soil about the roots of perennial plants, such as Iris spp. (Iridaceae) and Rhododendron spp. (Ericaceae). In the United States, the Japanese beetle is found in all states east of the Mississippi River except Florida and parts of Wisconsin, Minnesota, Iowa, and Nebraska (224).

Beside its native countries of origin and the United States, the Japanese beetle can be found in Canada (New Brunswick, Nova Scotia, southern Ontario, Prince Edward Island, and Quebec). The spread of the Japanese beetle in North America appears to be largely influenced by temperature and rainfall. It is also found in Portugal (Azores), where it is believed to have spread from a United States Air Force base in the early 1970s. The beetle does better in regions where the mean soil temperature during the summer is between $17{ }^{\circ} \mathrm{C}$ and $27{ }^{\circ} \mathrm{C}$ and winter soil temperature is above $-9.4{ }^{\circ} \mathrm{C}$, plus in regions where the rainfall is uniformly distributed throughout the year, averaging not less than $25 \mathrm{~cm}$ during the summer (225).

\section{Plant hosts}

The Japanese beetle is an insect pest of lawns and pastures, and many field and garden crops in the United States. FLEMING (226) gave a comprehensive list of the food plant of the insect in North America and elsewhere. The beetle appears to show seasonal variation in its food preference, but the preferred hosts include species of Rhus (Anacardiaceae), Asparagus (Asparagaceae), Betula (Betulaceae), Clethra (Clethraceae), Pteridium (Dennstaedtiaceae), Vaccinium (Ericaceae), Glycine, Wisteria (Fabaceae), Castanea (Fagaceae), Juglans (Juglandaceae), Sassafras (Lauraceae), Lagerstroemia (Lythraceae), Althaea, Hibiscus, Malva, Tilia (Malvaceae), Melia (Meliaceae), Oenothera (Onagraceae), Platanus (Platanaceae), Zea (Poaceae), Polygonum, Rheum (Polygonaceae), Malus, Kerria, Prunus, Rosa, Rubus, Sorbus, Ulmus (Rosaceae), Populus, Salix (Salicaceae), Acer, Aesculus (Sapindaceae), Ampelopsis, Parthenocissus, and Vitis (Vitaceae).

Other recorded food plant of the Japanese beetles include species of Abutilon, Acalypha, Alcea, Alnus, Agrostemma, Ambrosia, Apocynum, Aralia, Berberis, Beta, Brassica, Buddleia, Calendula, Campsis, Canna, Carya, Cassia, Catalpa, Chaenomeles, Cichorium, Citrus, Crataegus, Cydonia, Dahlia, Deutzia, Digitaria, Erigeron, Eupatorium, Exochorda, Fagus, Fragaria, Galium, Geranium, Gladiolus, Gossypium, Halesia, Helianthus, Hypericum, Impatiens, Impomoea, Kerria, Larix, Lespedeza, Ligustrum, Linaria, Lindera, Lobelia, Medicago, Mirabilis, Myrica, 
Nelumbo, Nicotiana, Nuphar, Nyssa, Osmunda, Oxalis, Paeonia, Pelargonium, Peltandra, Phaseolus, Pisum, Pontederia, Quercus, Rhexia, Rhododendron, Ribes, Ricinus, Rumex, Sagittaria, Salvia, Solidago, Spiraea, Tagetes, Taxodium, Toxicodendron, Trifolium, Typha, Vernonia, Viburnum, Weigela, and Zinnia.

\section{Classification and description}

The Japanese beetle, Popillia japonica, is a scarab beetle, or Scarabaeidae in the superfamily Scarabaeoidea. Scarab beetles can be recognized by their oval-shaped body, five-segmented tarsi, and a lamellate antenna club that can be closely apposed to form a tight club. However, the clubs can spread apart like a fan in the live beetle and may remain so after death. The elytra epipleura is narrow and ends before reaching the apex of the elytra. The abdomen has six visible sternites.

The genus Popillia is placed within the subfamily Rutelinae. Members of this subfamily can be distinguished from other scarab beetles using the following characteristics: elytra not covering the abdomen completely, pygidium exposed; tarsi with two unequal claws, or with only one large claw; posterior tarsi with two claws; if with given color pattern then pubescence on head, pronotum and elytra long, not scale-like, and (usually) dark; and body at least in part with metallic coloration.

According to SARKAR et al. (226), the genus Popillia may easily be identified by the following characters: body short, oval and convex; shiny; labrum horizontal; antennae 9segmented; head short; clypeus short, front margin reflexed and round at angles; pronotum weakly octagonal, sides sinuate, base trisinuate and excised above scutellum; scutellum elongate; elytra punctate striate, external margins often with membranous flange; propygidium and pygidium with tuft of yellow hairs; fore tibia bi- or tridentate, mid and hind tibiae carinate externally and truncate at extremity. The adult Japanese beetle (Figure 15) is oval, varying from 8 to $11 \mathrm{~mm}$ in length and 5-7 mm wide (226). Males are slightly smaller than females. The body is a brightly colored metallic green, with bronze or coppery-brown elytra. Elytra have fine longitudinal lines, and do not completely cover the abdomen. The Japanese beetle can readily be

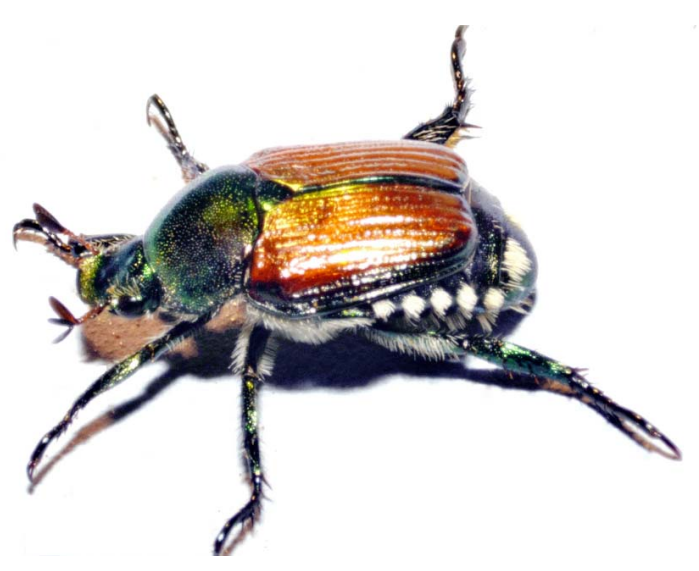

Figure 15. The adult Japanese beetle, Popillia japonica (photograph by Peter Edde).
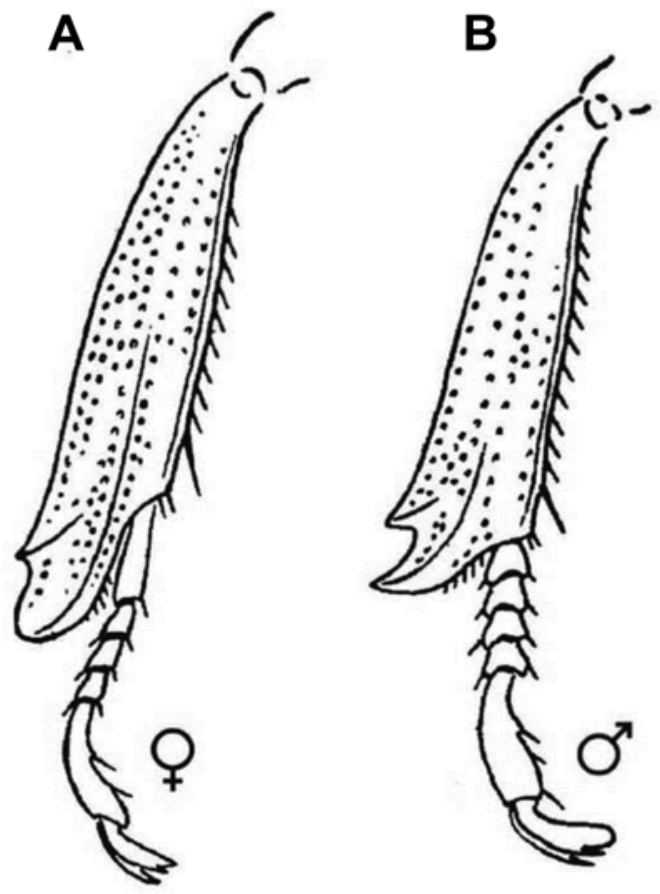

Figure 16. The front leg of the Japanese beetle showing differences in the tibia and tarsus between (A) female and (B) male beetles [adapted from FLEMING (226)].

distinguished from other common scarabaeid adults by the presence of five lateral tufts of white hair on each side of the abdomen and two patches of white hairs on the dorsal surface of the last abdominal segment, just under the edges of the elytra.

The sexes can be separated by the differences in the tibia and tarsus of front legs. As shown in Figure 16, the male proximal four tarsal segments are wider than they are long, while those of the female are as long as or longer than they are wide. The differences are more obvious in the first tarsal segment (225). The apex of the tibial spur of the male is more pointed, while it is spatulate or rounded in the female (Figure 16).

\section{Damage}

Damages caused by the Japanese beetle on tobacco are carried out by adult beetles and are limited to leaf tissues. Japanese beetles are gregarious in habit and feed on upper foliage, working their way downward on the plant. The beetle normally consumes the soft portions of the leaf surface, avoiding the veins. Attacked leaves have a ragged or skeletonized appearance (Figure 17). Severely damaged leaves turn brown and most of them drop off the plant. In addition to defoliation of plants, the Japanese beetle can cause severe injury to flowers and fruits. In corn, for example, the beetle prevents pollination by clipping silks during the early stage of silking; this results in malformed kernels and reduced yield.

Japanese beetle larvae (Figure 18) feed underground on the roots of a wide variety of plants, including ornamental plants, grasses, and vegetables. Their feeding weakens plant growth and reduces resistance to drought, especially in turf in lawns, parks, golf courses, and pastures. 


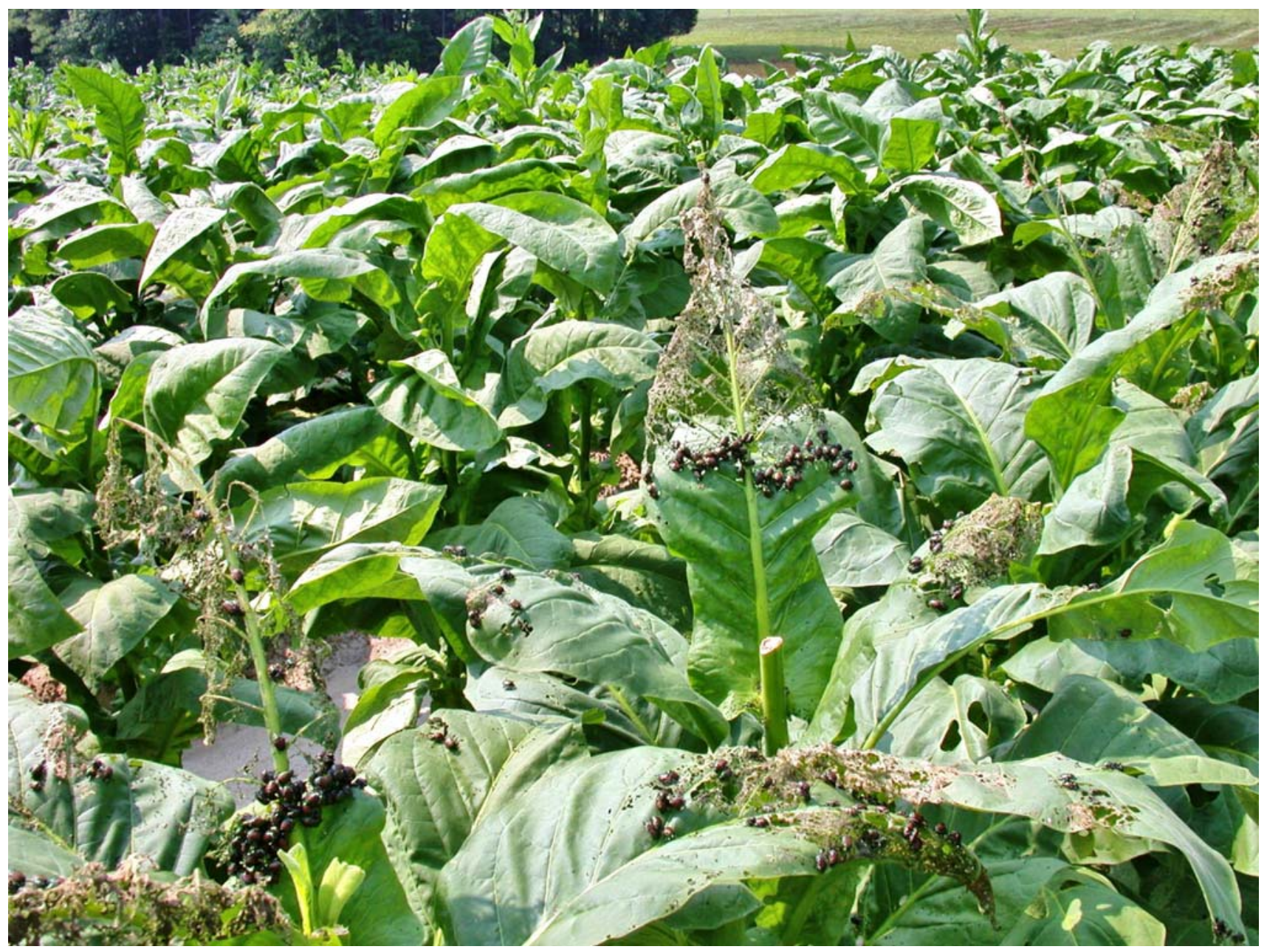

Figure 17. Japanese beetle damage to tobacco leaves. Adults chew out the tissue between the veins, leaving a vein skeleton (photograph by Whit Morris, with permission).

\section{Biology and ecology}

DAVIS (228), HAWLEY (229), FLEMING (226), RÉGNIÈRE et al. (230), and VITTUM (231) have provided information on the general biology and ecology of the Japanese beetle. POTTER and HELD (224) gave a detailed literature review of the biology and management of the insect. GOONEWARDENE and ZEPP (232) described a method for rearing the immature stages of the Japanese beetle. SIM (233) described the morphological characters useful in distinguishing larvae of the Japanese beetle and other introduced Scarabaeidae found in the United States. RODRÍGUEZ et al. (234) and BARROWS and GORDH (235) provided details on the mating behavior of $P$. japonica; BARROWS and GORDH (235) provided comparative notes on the sexual behavior of other scarabs.

The Japanese beetle overwinters as second or third instar in an earthen cell typically $5-15 \mathrm{~cm}$ below the soil surface, although a few may be found below $20 \mathrm{~cm}$. The overwintering larvae become active in spring as soil temperatures rise above $10^{\circ} \mathrm{C}$, moving upward in the soil surface, and starting to feed on plant roots (226). The larvae feed for about 4-8 weeks, then go slightly deeper and form an earthen cell in which to pupate (224). The prepupal stage occurs in May and lasts about 10 days. The pupae trans- form into the adult stage in about 2 weeks, after which the adults emerge to renew the cycle. The newly formed adults stay in their earthen cells for several days, while their bodies and wing covers become hardened.

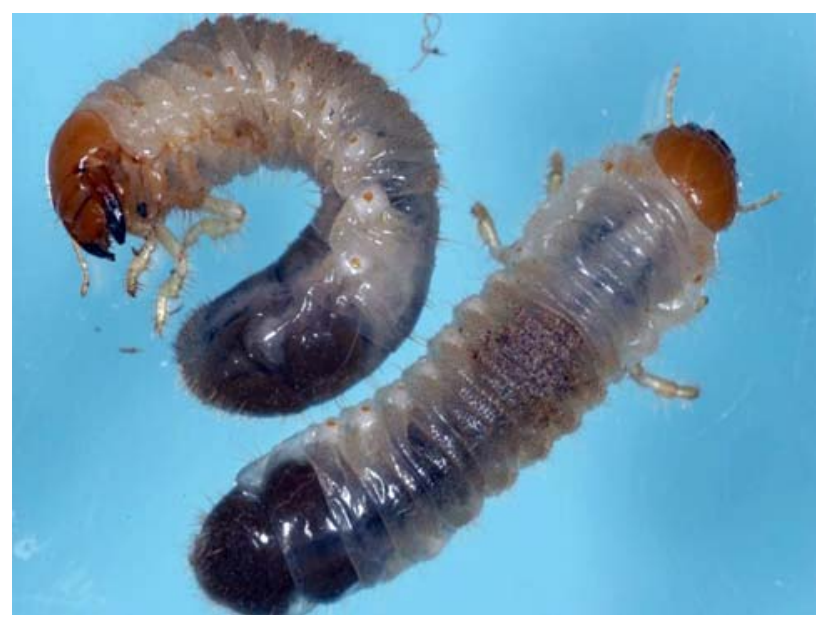

Figure 18. Full-grown Japanese beetle larva (photograph courtesy of Phil Sloderbeck, Department of Entomology, Kansas State University). 
Female Japanese beetles typically emerge from the soil a few days earlier than males (230). VITTUM (231) reported that while $P$.japonica's reproductive systems develop quite rapidly, the majority of the beetles are not fully mature when they first emerge from the soil and initiate flight. After emerging from the ground they climb onto the low-growing plants close to their point of emergence, and they rest for some time before flying to seek food and to mate. The average lifespan of the adult Japanese beetle with access to food is about 30-45 days, and adults deprived of food and water can survive for about 7-9 days (226). In North Carolina, adult beetles begin to emerge from the soil as early as the last week of May, reaching maximum abundance in mid to late June, and then decline until only a few are found after the middle of August (230). Virgin female Japanese beetles attract conspecific males for mating by emitting a volatile sex pheromone. Male beetles are strongly drawn to this volatile pheromone, such that clusters of males may be observed to surround the newly emerged virgin female, all attempting to copulate with her. Japanese beetle pheromone has been identified as $(R, Z)-5$-(-)-(1-decenyl)oxacyclopentan-2-one (236). The synthetic form of the female-produced pheromone is given the trivial name "Japonilure". Although female Japanese beetles produce pheromone to attract males, females too can detect their species' sex pheromone (237).

Japanese beetles mate at any time of the day, but preferably in the early morning or in the evening (226). BARROWS and GORDH (235) described the mating behavior of the insect. Briefly, the male approaches and mounts the female from behind, grasping the female elytra with his forelegs and the female hind legs with the mid and hind leg, followed by insertion of aedeagus, and staying coupled in this manner for an average of $2 \mathrm{~min}$. The male then withdraws the aedeagus, but usually stays mounted on the back of the female for up to $2 \mathrm{~h}$ without genitalia contact, a phenomenon referred "mate guarding". BARROWS and GORDH (235) found that $P$. japonica is polygamous in the laboratory and shows homosexual behavior. They also noted that other males often try to displace the mating male during intromission or mate guarding. Male Japanese beetles usually court the female while they are mounted, rubbing the females with their antennae and hind legs.

RODRÍGUEZ et al. (234) reported that the male Japanese beetle produces substrate-borne vibrational signals beginning when attempting to mount the female and continuing through to mate guarding, presumably to induce the female to accept the male's attempts at intromission and increasing the likelihood of the female accepting the male's sperm or refusing or delaying remating.

The female Japanese beetle lays 40-60 eggs during her lifetime. The eggs are deposited at intervals throughout the lifespan of the insect. The female burrows to a depth of $2.5-10 \mathrm{~cm}$ and deposits $1-4$ eggs, returning above ground to resume feeding between egg-laying sessions. The preferred oviposition site is medium-moist, loamy soil with closely cropped grass, such as that found in lawns, pastures, and golf greens and fairways. In their absence, females will deposit their eggs in less favorable conditions, such as plant beds and cultivated ground. The end of the oviposition period occurs in mid-July in North Carolina, USA (230).
The size, shape, and color of newly deposited eggs vary. FLEMING (226) noted that some eggs are spheroids about $1.5 \mathrm{~mm}$ in diameter, some are ellipsoids measuring $1.5 \mathrm{~mm}$ in length and $1.1 \mathrm{~mm}$ in diameter, and others tend to be slightly cylindrical. Egg color ranges from a translucent white to creamy. The external surface of the chorion is marked with small hexagonal areas. As the embryo develops, the egg increases in size becoming about twice the size as the newly deposited egg, and it becomes almost spherical in shape. The eggs hatch in about 10-14 days under summer conditions.

When newly hatched, the larvae are translucent creamy white, about $1.5 \mathrm{~mm}$ long, heads with prominent darkcolored mandibles, three pairs of thoracic legs and ten abdominal segments. Fecal matter accumulates in the hindgut when they start feeding, making the larvae to appear grayish black. In general, the larvae are similar in shape and appearance to other common scarabaeid larvae found in crop fields or turfgrass. The larvae pass through three instars (230). First instars feed for 2-3 weeks, molt to the second instar, and feed for an additional 2-4 weeks before molting to the third instar in September (231). As the larvae mature, they become grayish white with a yellowish brown head. The larva is about $25 \mathrm{~mm}$ long when fully grown, and it is usually found beneath the soil surface, curled in a C-shape. FLEMING (226) estimated the head of the first-instar grub to average $1.2 \mathrm{~mm}$ in width and $0.7 \mathrm{~mm}$ in length, while the head of the second instar is $1.9 \mathrm{~mm}$ wide and $1.2 \mathrm{~mm}$. long, and the head of the third instar is $3.1 \mathrm{~mm}$ wide and $2.1 \mathrm{~mm}$ long.

There are several other scarabaeid larvae that live under the same conditions and have the same general appearance as the larvae of the Japanese beetle. The larvae most likely to be mistaken for the larvae of the Japanese beetle include those of the brown May beetles (Lachnosterna spp.), of certain leaf chafers (Anomola spp.), the rose beetle or chafer (Alacrodactylus suhspinosus), and of another common May beetle-like species (Cyclocephala) (228). The difference between these scarabaeid larvae and the larvae of the Japanese beetle is that the ventral side of the last abdominal segment of the Japanese beetle larvae has a small V-shape suture with rows of 6-7 hairs. The general movements of the Japanese beetle larvae in the soil are vertical, whereas the larvae of other scarab beetles, such as the southern masked chafer Cyclocephala immaculata and Anomala sp., usually feed and move in a direction parallel with the surface of the ground, and most of the feeding by Japanese beetle larva is done between $1.3 \mathrm{~cm}$ and $7.6 \mathrm{~cm}$ below the surface (238).

Japanese beetle larvae feed well into October or early November, and most are nearly full-sized before the onset of winter. RÉGNIÈRE et al. (230) noted that most of the overwintering larvae in North Carolina are in the third instar, but some part of the population may overwinter in the second instar in cool years when the beetle season is late and oviposition could continue well into August. The Japanese beetle has a one-year life cycle in most regions of the United States and Canada where it has been established. However, at the northern edge of its range in the United States and parts of Canada, some individuals of the population may need 2 years to complete the life cycle (231). 


\section{Management}

\section{- Scouting technique}

Japanese beetle feeding damage is often minor and thus may not require treatment. The entire field should, however, be scouted regularly during the growing season to identify plant injury caused by the beetle so that it is not confused with injury by more significant insect or pathogen pests. Japanese beetles are abundant enough to cause injury to plants usually from late June to the middle of August (196). The insect may feed on tobacco during the latter half of the growing season. Preliminary findings suggest that tobacco varieties low in nicotine content are likely to suffer greater injury under heavy Japanese beetle infestation (EDDE, personal communication).

Adult Japanese beetles feed heavily on warm sunny days, when the temperature ranges from $29^{\circ} \mathrm{C}$ to $35^{\circ} \mathrm{C}$, and the relative humidity is above $60 \%$ (239). Feeding activity typically begins at about $2 \mathrm{~h}$ after sunrise and ends at about 3-4 h before sunset. Japanese beetle population can be highest at the field edges; the entire field should, however, be scouted to figure out if the beetle population is distributed throughout.

Traps baited with a combination of a sex attractant and a floral lure are commercially available for trapping Japanese beetles. These traps will attract both sexes of the adult beetles and are useful to monitor for adult emergence and flight activity of the insect. Although Japanese beetle larvae will damage the roots of tobacco plants, the decision to treat with insecticide application is often based on feeding damage done to tobacco leaves by adults. Therefore, an estimate of pest density or defoliation should be obtained during scouting. However, in other agroecosystems such as pasture or turf grass, most of the economic damage is due to larval feeding activities beneath the soil surface. An estimate of Japanese larva can be obtained by sampling several square meter sections of field by using a shovel or spade to cut out a square meter section and lift the turf back to count the grubs.

\section{- Action threshold}

No exact thresholds for Japanese beetles have been established on tobacco. In the United States, researchers at North Carolina State University estimated that treatment may be justified if $10 \%$ of the plants are damaged and the insects are still present in the fields (27). If damage is present but no or very few insects are observed, treatments will provide no benefit.

\section{- Non-chemical}

Depending on field size, Japanese beetle populations may be kept below economic injury levels by removal from their food plants by hand picking or sweep netting. This is best done in the morning when the temperature is low and the beetles are sluggish. The beetles may then be killed by being dropped into a container holding soapy water. To obtain the best result, hand picking or sweep netting should be carried out in early stages of an infestation, done regularly and thoroughly throughout the beetle season.
Hand picking or sweep netting is labor intensive and does not prevent reinfestation from outside sources. Insecticide applications may be necessary to control if the beetle population is high.

Smartweed, Polygonum pensylvanicum, another pest of tobacco plant in the United States, is a preferred food plant of the adult Japanese beetle. In fields where the Japanese beetle is a problem, and where smartweed is also present, MANLEY (240) suggested that the use of pesticides (for weed and beetle control) can be minimized if growers let smartweed grow in the skip rows to allow the beetle to feed on them until the weeds are nearly eliminated, and the beetles are then controlled using insecticide spray on the skip rows.

\section{- Natural enemies}

Consult FLEMING (241) and CAPPAERT and SMITLEY (242) for detailed information on biological control agents of the Japanese beetle. The following natural enemies are effective to manage the Japanese beetle:

- Vertebrates - the amphibian Bufo lentiginosus (Bufonidae); moles Condylura cristata, Scalopus aquaticus (Talpidae); shrew Blarina brevicauda (Soricidae); skunk Mephitis mephitis (Mephitidae); and birds, Colinus virginianus (Odontophoridae), Myiarchus crinitus, Tyrannus tyrannus (Tyrannidae), Corvus brachyrhynchos (Corvidae), Sturnus vulgaris (Sturnidae), Agelaius phoeniceus, Quiscalus quiscula, Sturnella magna (Icteridae), Melospiza melodia, Passer domesticus, Pooecetes gramineus (Passerellidae), Cardinalis cardinalis (Cardinalidae), Dumetella carolinensis, Toxostoma rufum (Mimidae), Hylocichla mustelina, and Turdus migratorius (Turdidae).

- Diptera - tachinid flies, including Dexia ventralis, Erythrocera genalis, Eutrixopsis javana, Hamaxia incongrua, Istocheta spp., Pexopsis clauseni, Prosena siberita, and Trophops clauseni (Tachinidae).

- Hymenoptera - wasps in the genus Tiphia, (Tiphiidae), and scoliid wasps, including Campsomeris spp., and Scolia japonica (Scoliidae) are important parasitoids of Japanese beetle larvae; ants, especially Solenopsis molesta (Hymenoptera: Formicidae) is an important insect predator of Japanese beetle eggs.

- Pathogens - Bacillus lentimorbus (Bacillaceae) and Paenibacillus popilliae (formerly Bacillus popilliae) (Paenibacillaceae) are obligate parasites and causal agents of milky spore disease in Japanese beetle larvae; other bacterial pathogens of the beetle include Bacillus thuringiensis galleriae, Bacillus thuringiensis japonensis, Bacillus thuringiensis thuringiensis (Bacillaceae), and Rickettsiella popilliae (Rickettsiaceae).

- Fungi-Nomuraea rileyi, Metarhizium anisopliae, and Beauveria bassiana (Clavicipitaceae) can cause diseases in Japanese beetle larvae; entomogenous Coelomycetes, Entoderma colletosporium has been described from the cuticle of Japanese beetle (243). The fungus is believed to grow only in the endocuticle and epidermis of Japanese beetle larvae.

- Microsporidian - Ovavesicula popilliae (Microsporidia: Ovavesiculidae) is known to infect both Japanese beetle larvae and adults (244); eugregarinidan 
Stictospora villani (Apicomplexa: Eugregarinida: Actinocephalidae) has been described from larvae of the Japanese beetle (245)

- Nematodes - Several species of the nematodes Heterorhabditis (Heterorhabditidae) and Steinernema (Steinernematidae) attack and kill several types of soil-dwelling insects, including Japanese beetle larvae.

\section{- Chemical}

Insecticide control for adult beetles include the use of broad-spectrum insecticides, including acephate, bifenthrin, deltamethrin, halofenzide, imidacloprid, trichlorfon, thiamethoxam, spinosad + gamma-cyhalothrin, lambda-cyhalothrin, zeta-cypermethrin + bifenthrin, gamma-cyhalothrin, methyl parathion, carbaryl, and cyfluthrin.

\section{TOBACCO WIREWORM - Conoderus vespertinus} Fabricius, 1801

\section{Taxonomic position}

Order: Coleoptera

Family: Elateridae

\section{Common name}

Tobacco wireworm

Synonyms

Elater vespertinus Fabricius, 1801

Conoderus finitimus Say, 1836

Elater finitimus Say, 1839

Monocrepidius texanus Candeze, 1859

Monocrepidius peninsularis Candeze, 1889

Monocrepidius serotinus Germar, 1839

Monocrepidius vespertinus Fabricius, 1920

\section{Damaging stages}

Larva

\section{Distribution}

The tobacco wireworm, Conoderus vespertinus, is widely distributed in Eastern North America.

\section{Plant hosts}

Wireworms live and feed on the underground portions of many plants including corn, carrot, cotton, cowpea, lima bean, potato, sorghum, small grains, various vegetables, and tobacco.

\section{Classification and description}

Wireworms are the larval stage of adult beetles in the family Elateridae. Insects in this family are referred to as "click beetles," "skip-jacks," "snapping beetles," etc. Elateridae can be readily recognized by their elongated appearance and narrow body form, a large and freely articulating prothorax, with sharp posterior angles on the pronotum. Elaterids invariably possess a prosternal prolongation or spine, which is produced posteriorly and loosely fits into a cavity in the mesosternum $(246,247)$. The fore coxae are globular with the cavities open behind, while the hind coxae are transverse and contiguous (246). The tarsi on all pairs of legs are 5-segmented. Abdomen has five (rarely six) visible and usually separate and equally distinct sternites, the last two connected by a membranous suture (247). The elytra are strongly constructed, narrowing gradually posteriorly. Antennae are toothed or pectinate, and are generally 11-12-segmented.

Adult elaterids can be distinguished from the related Cerophytidae (rare click beetles) and Eucnemidae (false click beetles) in that the Elaterids have the prothorax loosely joined to the mesothorax. This allows the movement necessary for the spine on the prosternum to snap into a corresponding notch on the mesosternum. This usually bounces the insect into the air, often with audible snapping noise, when the beetle attempts to right itself when it is placed on its back. This behavior has earned click beetles their common name.

Conoderus are moderate to large sized beetles $(6 \mathrm{~mm}$ or longer). VAN DYKE (248) has provided keys to separate C. vespertinus from other members of the genus. Adult C. vespertinus (Figure 19) are elongate, flattened, with shiny dark reddish brown color above including entire ventral surface. The body tapers toward the rear end and is clothed in yellowish setae. The antennae have 11 segments, with the second antennal segment being longer than it is wide. The prothorax is longer than broad; it is finely, uniformly, and closely punctured. A pitch-black broad longitudinal stripe is distinctly visible on each side, which narrows toward the head. The elytra are striated with parallel small grooves, and have a broad sutural longitudinal stripe from base, which gradually broadens basally and suddenly expands before the apex to meet the lateral at apical two-thirds. The hind angles of the thorax are elongated into points alongside the abdomen. The fourth tarsal segments are lobed or broadened beneath, with the lamella visible from above.

Several species of elaterids closely resemble the tobacco wireworm. The southern potato wireworm, Conoderus falli, and the Gulf wireworm Heteroderes amplicollis the most common of these are also associated with tobacco (249251). DAY et al. (251) and NORRIS (252) provided detailed

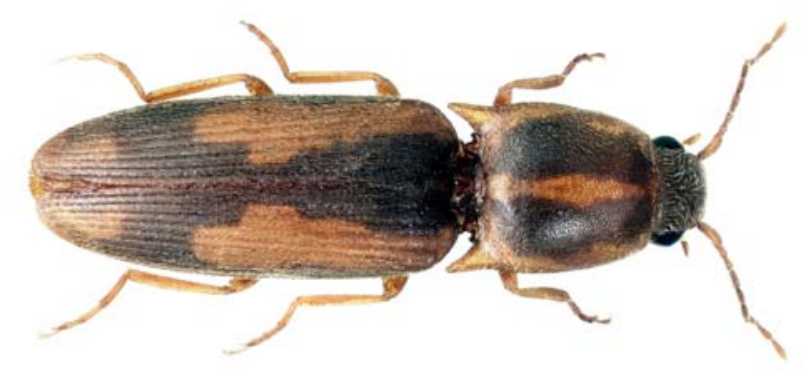

Figure 19. Adult tobacco wireworm, Conoderus vespertinus (photograph courtesy of Natasha Wright, Florida Department of Agriculture and Consumer Services, https://Bugwood.org). 
descriptions of the different life stages and biology of $C$. falli; similar information for Heteroderes amplicollis was provided by COCKERHAM and DEEN (253) and STONE and WILCOX (254).

\section{Damage}

C. vespertinus larvae (Figure 20) damage tobacco by tunneling into the stalk below the soil surface. The plants are susceptible within $24 \mathrm{~h}$ after transplanting, and most of the injury often takes place within 2 or 3 weeks after the plants have been set in the field (209). Wireworm feeding and tunneling prevents vigorous plant growth, opens plants to soil-borne pathogens, and some of the plants may be killed. When stunted plants are dug up and the stems are split open, one or more wireworms may be seen (Figure 21). Further examinations of the soil immediately around the area where the plant was dug up often reveals additional wireworm larvae. Loss of tobacco stands may necessitate extensive replanting and uneven stands of tobacco. Replanting also results in plants of varying size and maturity, which are costly and difficult to manage. This makes agronomic practices such as topping, suckering, and harvesting more difficult to manage, and therefore more expensive.

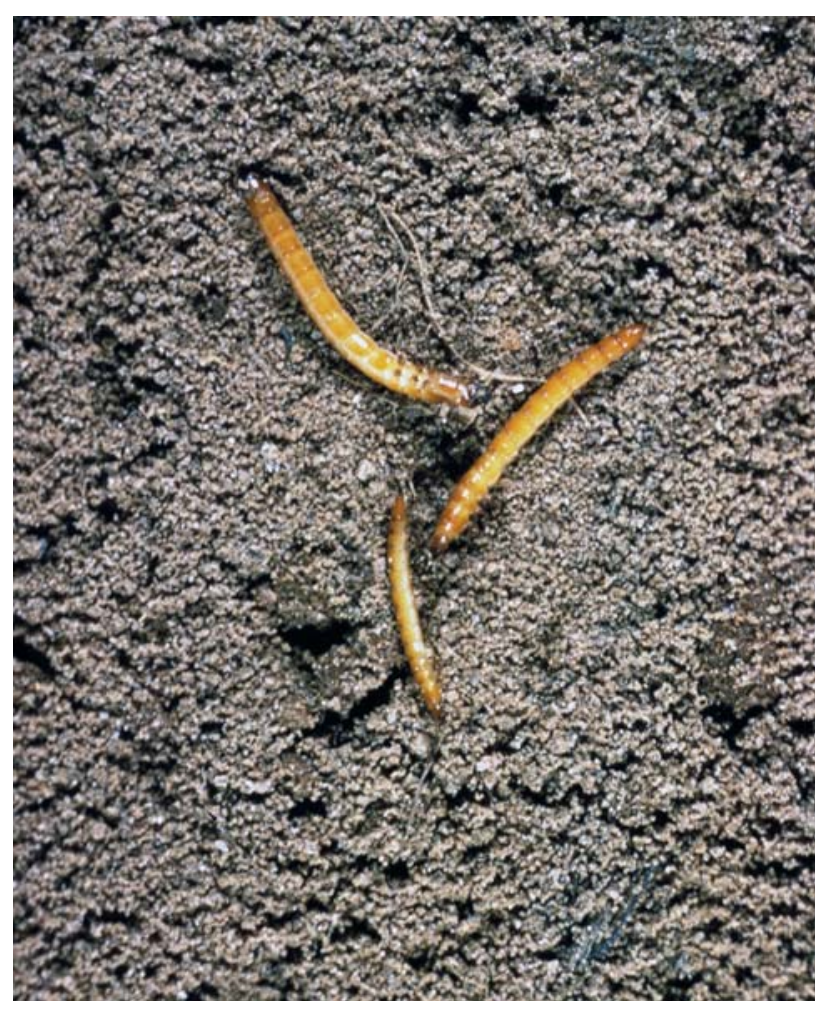

Figure 20. Wireworm larvae (photograph courtesy of R.J. Reynolds Tobacco Company, https://Bugwood.org).

\section{Biology and ecology}

CONRADI and EAgERTON (255), TURnipseEd (256), TURNIPSEED and RABB (257), and RABB (110) have described various aspects of the biology and ecology of the

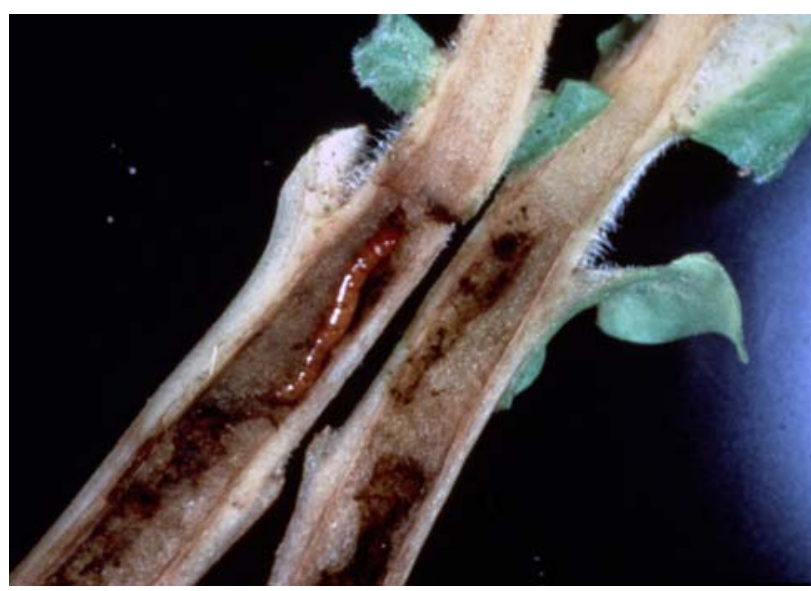

Figure 21. Tobacco plants severely injured by wireworms (photograph courtesy of R.J. Reynolds Tobacco Company, https://Bugwood.org).

tobacco wireworm. The bionomics of the species appears similar to that of the southern potato wireworm and Gulf wireworm (251-254). EDWARDS and EVANS (258) provided a literature review on methods of rearing wireworms.

The tobacco wireworm overwinters in the larval stage in the soil. The insect completes its larval development, and then pupates the following spring. They usually remain in the pupal cell for 2-3 days to allow the exoskeleton to harden and darken. Preoviposition period ranges from 5-25 days and averages 13 days (110). TURNIPSEED (256) reported the average time from eclosion to oviposition to be 7.3 days and 8.7 days for females reared in insectary and field cages, respectively. Female tobacco wireworms typically deposit their eggs during evening hours within the top $1.3 \mathrm{~cm}$ of soil in the summer (254). The numbers of eggs laid by female tobacco wireworms vary considerably. RABB (110) reported that females lay 8-629 eggs (average 240 eggs). This observation is similar to that of TURNIPSEED (256) who observed an average of 223 eggs deposited on blotters and 394 on soil. In contrast, CONRADI and EAGERTON (255) found the number of eggs laid per female to be much lower, the average being 61 eggs.

Newly laid eggs are pearly white, spherical, about $0.5 \mathrm{~mm}$ in diameter, and they are laid on or slightly beneath the soil surface (255). The eggs darken as embryological development proceeds. The number of days required for the incubation decreases with increasing temperature. In southeastern United States, wireworm eggs laid in the field may hatch in about 5-10 days in midsummer, but may require from $20-30$ days in early spring and late fall $(251,255)$.

Elaterid larvae vary considerably in size. They are typically subterranean for the majority of their life as larvae progressing through multiple instars. Their bodies are straight, hard elongate, cylindrical, shining, and varying in color from pale yellow to dark red-brown. The body bears only three pairs of five-segmented thoracic legs. The labrum is fused to the clypeus and the anterior margin of frons to form a tooth-like projection or projections known as the nasale $(246,247)$. The maxillae and labium are elongate and fused. The frontoclypeal area is usually lyre-shaped and quite characteristic of the family (246). Spiracles are biforous (247). When viewed dorsally, the abdomen 
appears nine-segmented, but is actually ten-segmented. The tenth segment, which is extremely variable in shape, appears as a projection from the ventral surface of the ninth and bears the anus (246). A horn-like terminal projection, known as urogomphus, surrounding a caudal notch, may sometimes be visible on the ninth abdominal segment.

Newly hatched larvae of the tobacco wireworms are about $1.4 \mathrm{~mm}$ long, $0.3 \mathrm{~mm}$ wide, creamy white, except the head capsule, which is slightly tinged with yellowish-brown. Information is lacking on the number of instars or the duration of other stadia of tobacco wireworms. NORRIS (252) reported that the congeneric, $C$. falli, pass through five to seven instars in Florida, USA. Some wireworm species found in the Virginia, USA are also known to have as many as seven to ten larval instars and can remain in the soil for several years as larvae, moving up and down the soil profile as temperatures and moisture change (259). The first instar larvae of the tobacco wireworm differ from subsequent instars in the structure of the terminal (ninth) abdominal segment. This segment ends in a single point bearing two setae, whereas in subsequent instars, it terminates in a V-shaped notch between two bifurcate urogomphi (110). RABB (110) has provided a key to distinguish lateinstar larvae of common species wireworms found in tobacco growing regions in the United States.

RABB (110) reported that the duration of the first stadium of the tobacco wireworm reared under constant temperature was 5 days at $35^{\circ} \mathrm{C}$ and $10-15$ days at $23.9{ }^{\circ} \mathrm{C}$. None molted in 25 days at $12.8^{\circ} \mathrm{C}$, and none survived for 5 days at $40.6{ }^{\circ} \mathrm{C}$. Under favorable conditions, such as during late spring or midsummer, when temperatures are high and food is abundant, the larval stages may be completed in about 30 days (260). However, most larvae that develop in the fall typically overwinter in the larval stage and remain in the larval stage until the following spring. Consequently, development time in overwintering larvae, may last up to 300 days or more $(110,255,260)$. For example, RABB (110) found that the complete larval period varies from 287 to 347 days in field cages. Fully developed larvae of the tobacco wireworms are yellowish-brown and 14-19 mm long.

The matured larvae go into a period of inactivity, with regard to feeding, and form the prepupae. The prepupae is formed in earthen cells located $18-30 \mathrm{~cm}$ below the soil surface $(253,255)$. Studies with $C$. falli indicated that pupation does not occur when soil temperatures average below $18^{\circ} \mathrm{C}(251)$. The prepupal stage is characterized by a shortening in length, increase in girth, and decrease in activity. Some active larvae may pupate within $12 \mathrm{~h}$ (110). The advanced prepupa stage may be recognized by its movements when disturbed. It rolls and twists its body in the same manner as does the pupa.

The transformation from prepupa to pupa takes place in a small cell in the soil. Pupae are about 12-14 mm long, with legs, wings and antennae well developed and free (253). Pupae are almost pure white when newly formed but change to light brown before transforming to adult. Pupal duration decreases with increasing temperature. For example, RABB (110) found that the mean number of days for the pupation period is 4.4 days at $35{ }^{\circ} \mathrm{C}, 6.2$ days at $29.4^{\circ} \mathrm{C}$, and 11.4 days at $23.9^{\circ} \mathrm{C}$. In South Carolina, USA, the pupa stage lasts 10-12 days during the summer months, but may require a longer period later in the season when the temperature is lower (255). The newly formed adult stays in the pupal cell for 2-3 days during which time its exoskeleton hardens and darkens. The adult then emerges from the soil and mates.

The tobacco wireworm occurs from late April through July, depending on location (RABB, 110). Under laboratory conditions, C. falli adults have lived for 100 days (252). Generally, there is one generation of the tobacco wireworm annually in the tobacco growing regions of the United States. However, a small percentage of individuals may pass through two winters in the larval stage, and larvae of varying sizes and ages may be present in the soil at the same time due to the overlapping of generations.

\section{Management}

\section{- Scouting technique}

Wireworms are present in the soil at transplanting. Poorly drained soils or fields previously planted with grasses, grass-based pasture, or vegetable crops like carrots and potatoes can contribute to increasing the wireworm populations. Thus, the cropping history of a field sometimes provides a good indicator if wireworms are likely to be a problem in the current season. If the presence of wireworms is suspected, it may be necessary to sample the field for wireworms before transplanting the crop.

Fields should be evaluated for the potential of wireworm problems in the fall or in the spring when soil temperatures are above $7^{\circ} \mathrm{C}$ by inspecting the soil for wireworms when plowing and disking, or setting out grain bait stations (259). Wireworm baits (e.g., wheat, grain sorghum, rolled oats, or wheat/corm mixture) should be placed into a fine-mesh pouch and buried 10-15 cm deep at different marked sites throughout the field. The pouch should be retrieved after 1 week and examined to provide a relative estimate of wireworm populations in the field. The grains should be pre-soaked 1 day prior to enhance attractiveness of the baits to wireworm by promoting seed germination and release of carbon. Bait, at the rate of two pouches per acre, should be deployed randomly through the field. Bury the pouches with soil and mound the soil over the top in a dome shape so rainwater runs off. Cover the mound with a piece of clear or dark plastic and secure the edges of the plastic to increase soil temperature and improve bait performance for detecting wireworm infestation $(261,262)$.

Another method for sampling wireworms in the soil involves the collection of a series of soil core samples and sifts for the presence of the pest. Whenever possible, about 50 random soil samples should be collected per field. A soil core sample should be obtained for a similarly sized area, e.g., $15 \mathrm{~cm}$ diameter to a depth of $30 \mathrm{~cm}$. Sift the soil through a 8-mesh screen and record the number of wireworms found. Although tedious and labor-intensive, soil sampling allows for more accurate information on seasonal variations in the number and size of larvae and the number of pupae, and vertical and horizontal distributions of wireworm stages.

A review of literature on pheromone and attractants for click beetles has been provided [e.g., Тотн (263)]. 


\section{- Action threshold}

There is currently little information regarding wireworm threshold on tobacco.

\section{- Non-chemical}

Cultural control methods include the following practices:

- Avoidance of fields known to have wireworm infestation. Similarly, allowing fields to fallow helps to kill various life stages of the insects.

- Rotation of crops away from fields known to be infested with wireworms, or those that have been out of production, or previously planted with grass sod, weeds, or clover, corn, or small grains. Similarly, rotation of tobacco into these fields may result in significant wireworm problems even if the crop had previously not been planted there before; plowing and disking, especially in fall, helps to expose wireworms to their predators.

- Cultivation and irrigation help plants recover from wireworm damage.

- Plant in well-drained soils because wireworms are attracted to high moisture and densities are often higher in the wetter portions of a field.

\section{- Natural enemies}

Few insect parasites are known to attack wireworms, presumably due to the subterranean habits of the larvae. A review of parasitoids and predators of click beetle larvae is provided by TRAUGOTT et al. (264). However, there are various other natural enemies that attack wireworms and click beetles:

- Vertebrates - Various species of frogs, toads, moles, and birds are sometimes of importance in reducing wireworm levels because they may feed on the larvae that are exposed at the surface of the soil when a field is disked or cultivated $(255,258)$.

- Nematodes - Entomopathogenic nematodes, including Diplogaster sp. (Diplogasteridae), Heterorhabditis megidis (Heterorhabditidae), Steinernema feltiae, and $S$. riobrave (Steinernematidae) are important natural mortality agents of the wireworm.

- Fungi - Entomopathogenic fungi such as Beauveria bassiana and Metarhizium anisopliae (Clavicipitaceae) are also known to attack the pest. Bacteria pathogens of wireworms include Pseudomonas fluorescens, P. aeruginosa, Rahnella aquatilis, and various Bacillus spp. (264).

\section{- Chemical}

It is not possible to control wireworms in tobacco after wireworm damage has occurred. Decisions, therefore, must be made in advance as whether to use soil-applied insecticides. In fields with a history of wireworm problems, or in those previously planted after grass sod, weeds, corn, clover, or small grains, application of insecticide labeled as soil, tray drench, or transplant water treatments can help to provide effective control of wireworms on tobacco (107). Insecticides for wireworm control include beta-cyfluthrin, bifenthrin, chlorpyrifos, clothianidin, ethoprop, imidacloprid, lambda-cyhalothrin, and thiamethoxam.

\section{SUMMARY}

Management options for insect pest control on tobacco include biological, cultural, and chemical. However, the tobacco plant is food to a wide range of insect pests throughout the year, which makes it difficult to find a simple solution to insect pest control in the cropping system. A whole-farm approach or integrated pest management combines cultural, natural, and chemical controls to maintain insect pest populations below levels that cause economic damage to the crop.

However, a thorough knowledge of the target organism is important. Integration and effective use of various control components is often enhanced when the target organism is correctly identified and its biology and ecology are known. An integrated approach to tobacco insect management includes the following aspects:

- Scouting for insects or damage on a regular basis throughout the growing season and taking timely control measures to prevent pest populations from reaching economic injury levels.

- Growers should be familiar with the economic thresholds for the pest and use them to help with pest-control decision making.

- Adoption of simple cultural practices to help keeping pest populations below damaging levels. Some of the measures include

(i) Destruction of solanaceous weeds in the immediate vicinity of greenhouses to prevent migration of potential tobacco pests that feed on these crops from migrating into the greenhouses to damage tobacco seedlings. If greenhouses are used to produce other crops, a fallow period should be used to clear populations before seeding tobacco.

(ii) Keeping tobacco fields free of weeds after transplanting and avoiding to plant solanaceous crops near the field.

(iii) Early topping and effective sucker-control practices will aid in keeping populations of aphids, hornworms, and budworms down because they reduce food sources for these insects.

(iv) Effective timing of planting and harvesting to limit insect damage by enabling the plant to avoid the development of large pest populations.

(v) Conservation tillage strategies such as no-till and strip-till, which have been shown to reduce aphid and flea beetle populations, possibly because of increased biological control activity. However, such agronomic practices may cause an increase in other pests including cutworms, vegetable weevils, and slugs.

(vi) Proper timing of land operations such as tillage, stalk cutting, and root destruction are essential to help reduce pest population for the following growing season because several species survive the winter season in the soil as larvae or pupa.

(vii) Use of crop rotation and planting cover crops to avoid pest build-up and help support soil fertility. 
- A variety of predatory and parasitic insects, spiders, diseases, and insectivorous birds and mammals attack tobacco insects at various stages of their life cycle. Natural enemies seldom eradicate the destructive stages of the pest but may reduce infestations to below the economic threshold. The careful use of broad-spectrum insecticides is required in order to avoid disruption of these biological control agents, especially predators and parasitoids.

- Chemical insecticides are still the only viable option to control of most of the economically important pests on tobacco, including aphids, budworm, and thrips. The goal should be to minimize the selection for resistance to any type of pesticide, or to help regain susceptibility in insect pest populations in which resistance has already developed. Integrated pest management is therefore important in keeping the efficacy of valuable insecticides. Key elements in achieving this goal include the use of alternations, sequences, or rotation of different insecticides in the management of the pests. It is also important to have good understanding of insecticides as they are grouped according to similarity of mode of action in controlling the target pest.

\section{ACKNOWLEDGMENTS}

I thank Dr. Paul J. Semtner and three anonymous reviewers for their insightful comments on the manuscript.

\section{REFERENCES}

1. Sierro, N., J.N.D. Battey, S. Ouadi, N. Bakaher, L. Bovet, A. Willig, S. Goepfert, M.C. Peitsch, and N.V. Ivanov: The Tobacco Genome Sequence and its Comparison with Those of Tomato and Potato; Nat. Commun. 5 (2014) 4833. DOI: 10.1038/ncomms4833

2. Knapp, S., M.W. Chase, and J.J. Clarkson: Nomenclatural Changes and a New Sectional Classification in Nicotiana (Solanaceae); Taxon 53 (2004) 73-82. DOI: $10.2307 / 4135490$

3. Goodspeed, T.H.: The Genus Nicotiana. Origins, Relationships and Evolution of Its Species in the Light of Their Distribution, Morphology and Cytogenetics; Chronica Botanica Company, Waltham, MA, USA, 1954, and Stechert-Hafner, Inc., New York, NY, USA, 1955.

4. USDA: National Plant Germplasm System; available at https://www.ars-grin.gov/npgs/, 2018. (Accessed September 2018)

5. Johnson, P.R.: The Economics of the Tobacco Industry; Praeger, New York, NY, USA, 1984.

6. CABI: Invasive Species Compendium: Myzus persicae (Green Peach Aphid); available at: http://www.cabi.org/isc/datasheet/35642. (Accessed September 2018)

7. Semtner, P.J., W.M. Tilson, and S.K. Dara: Performance of the Tobacco Aphid (Homoptera: Aphididae) on Various Host Plants; J. Entomol. Sci. 33 (1998) 180-195.

8. Baker, A.C.: Generic Classification of the Hemip- terous Family Aphididae; Bulletin No. 826, U.S. Department of Agriculture, 1920.

9. Havill, N.P. and R.G. Foottit: Biology and Evolution of Adelgidae; Ann. Rev. Entomol. 52 (2007) 325-349.

DOI: 10.1146/annurev.ento.52.110405.091303

10. Eastop, V.F.: A Taxonomic Study of Australian Aphidoidea (Homoptera); Austr. J. Zool. 14 (1966) 399-592. DOI: 10.1071/ZO9660399

11. Blackman, R.L. and V.F. Eastop: Aphids on the World's Herbaceous Plants and Shrubs; 2 Volume Set, John Wiley \& Sons, Chichester, UK, 2006.

12. Howard, L.O.: The Principal Insects Affecting the Tobacco Plant; Agriculture Year Book for 1898, U.S. Department of Agriculture, Washington, DC, USA, 1899.

13. Gillette, C.P. and E.P. Taylor: A Few Orchard Plant Lice; Bulletin 133, Colorado Experiment Station, Fort Colling, CO, USA, 1908.

14. Chamberlin, F.A.: History and Status of the Green Peach Aphid as a Pest of Tobacco in the United States; Technical Bulletin No. 1175, U.S. Department of Agriculture, Washington, DC, USA, 1958.

15. Harlow, C.D. and E.P. Lampert: Resistance Mechanisms in Two Color Forms of the Tobacco Aphid (Homoptera: Aphididae). J. Econ. Entomol. 83 (1990) 2130-2135.

DOI: org/10.1093/jee/83.6.2130

16. Blackman, R.L.: Morphological Discrimination of a Tobacco-Feeding Form from Myzus persicae (Sulzer) (Hemiptera: Aphididae), and a Key to New World Myzus (Nectarosiphon) species; Bull. Entomol. Res. 77 (1987) 713-730.

DOI: $10.1017 / \mathrm{S} 0007485300012219$

17. Margaritopoulos, J.T., G. Malarky, J.A. Tsitsipis, and R.L. Blackman: Microsatellite DNA and Behavioural Studies Provide Evidence of Host-Mediated Speciation in Myzus persicae (Hemiptera: Aphididae); Biol. J. Linn. Soc. 91 (2007) 687-702.

DOI: $10.1111 /$ j.1095-8312.2007.00828.x

18. Ramsey, J.S., D.A. Elzinga, P. Sarkar, Y.-R. Xin, M. Ghanim, and G. Jander: Adaptation to Nicotine Feeding in Myzus persicae; J. Chem. Ecol. 40 (2014) 869-877. DOI: $10.1007 / \mathrm{s} 10886-014-0482-5$

19. Kanavaki, O.M., J.T. Margaritopoulos, N.I. Katis, P. Skouras, and J.A. Tsitsipis: Transmission of Potato Virus Y in Tobacco Plants by Myzus persicae nicotianae and M. persicae s.str.; Plant Dis. 90 (2006) 777-782. DOI: 10.1094/PD-90-0777

20. Devi, P.B. and T.K. Singh: Studies on the Morphometry of the Green Peach Aphid, Myzus persicae (Sulzer) (Homoptera: Aphididae); Entomol. Res. 37 (2007) 81-85.

DOI: $10.1111 / \mathrm{j} .1748-5967.2007 .00055 . \mathrm{x}$

21. Reed, T.D. and P.J. Semtner.: Influence of Temperature on Population Development of Two Color Morphs of the Tobacco Aphid (Homoptera: Aphididae) on Flue-Cured Tobacco; J. Entomol. Sci. 26 (1991) 33-38. DOI: 0.18474/0749-8004-26.1.33

22. McPherson, R.M.: Seasonal Abundance of Red and Green Morphs of the Tobacco Aphid (Homoptera: Aphididae) on Flue-Cured Tobacco in Georgia; J. 
Entomol. Sci. 24 (1989) 531-538.

DOI: $10.18474 / 0749-8004-24.4 .531$

23. Cheng, H.H. and J.J. Hanlon: Effects of Green Peach Aphid, Myzus persicae (Sulzer) on Yield and Quality of Flue-Cured Tobacco in Ontario; Tob. Sci. 29 (1985) 144-148.

24. Reed, T.D. and P.J. Semtner: Effects of Tobacco Aphid (Homoptera: Aphididae) Populations on Flue-Cured Tobacco Production; J. Econ. Entomol. 85 (1992): 1963-1971.

DOI: org/10.1093/jee/85.5.1963

25. Mistric, W.J. and G.B. Clark: Green Peach Aphid Injury to Flue-Cured Tobacco Leaves; Tob. Sci. 23 (1979) 23-24.

26. Cheng, H.H. and W.A. Court: Effects of Green Peach Aphid, Myzus persicae (Sulzer) on Certain Chemical Constituents of Flue-Cured Tobacco; Tob. Sci. 21 (1977) 134-135.

27. Burrack, H.: Tobacco Insect Management; in: 2015 Flue-Cured Tobacco Production Guide; edited by L.R. Fisher, North Carolina State University Coop. Ext. Serv., Raleigh, NC, USA, 2015, pp. 145-164.

28. Starý, P.: Aphid Parasites (Hymenoptera, Aphidiidae) of the Central Asian Area; Springer, The Netherlands, 1979. DOI: 10.1007/978-94-009-9637-3

29. Minks, A.K., P. Harrewijn, and W. Helle (Eds.): Aphids: Their Biology, Natural Enemies and Control; World Crop Pests, Volume 2 A, Elsevier Science Publishers B.V., Amsterdam, The Netherlands, 1987.

30. Bodenheimer, F.S. and E. Swirski: The Aphidoidea of the Middle East; Weizmann Science Press, Jerusalem, Israel, 1957.

31. Joshi, S., R.J. Rabindra, and T.P. Rajendran: Biological Control of Aphids; J. Biol. Control 24 (2010) 185-202.

32. Aslan, M.M., N. Uygun, and P. Starý: A Survey of Aphid Parasitoids in Kahramanmaras, Turkey (Hymenoptera: Braconidae, Aphidiinae, and Hymenoptera: Aphelinidae); Phytoparasitica 32 (2004) 255-263. DOI: 10.1007/BF02979820

33. Aslan, M.M., and N. Uygun: The Aphidophagus Coccinellid (Coleoptera: Coccinellidae) Species In Kahramanmaras, Turkey; Turk. J. Zool. 29 (2005) $1-8$.

34. Reed, T.D. and P.J. Semtner: Life History, Biology, and Control of the Tobacco Aphid; Viginia Cooperative Extension Service Publication No. 436-419, Viginia State Ploythenic and State University, Blacksburg, VA, 1989, pp 1-6.

35. Elkassabany, N.M., D.C. Steinkraus, P.J. McLeod, J.C. Correll, and T. E. Morelock.: Pandora neoaphidis (Entomophthorales: Entomophthoraceae): A Potential Biological Control Agent Against Myzus persicae (Homoptera: Aphididae) on Spinach; J. Kansas Entomol. Soc. 65 (1992) 196-199.

36. Shah, P.A., M. Aebi, and U. Tuor: Method to Immobilize the Aphid-Pathogenic Fungus Erynia neoaphidis in an Alginate Matrix for Biocontrol; Appl. Environ. Microbiol. 64 (1998) 4260-4263.

37. McLeod, P.J., D.C. Steinkraus, J.C. Correll, and T.E. Morelock: Prevalence of Erynia neoaphidis (Entomophthorales: Entomophthoraceae) Infections of
Green Peach Aphid (Homoptera: Aphididae) on Spinach in the Arkansas River Valley; Environ. Entomol. 27 (1998) 796-800. DOI: org/10.1093/ee/27.3.796

38. Liu, S., D. Vijayendran, J. Carrillo-Tripp, W.A. Miller, and B.C. Bonning: Analysis of New Aphid Lethal Paralysis Virus (ALPV) Isolates Suggests Evolution of Two ALPV Species; J. Gen. Virol. 95 (2014) 2809-2819. DOI: 10.1099/vir.0.069765-0

39. Williamson, C., E.P. Rybicki, G.G.F. Kasdorf, and M.B. von Wechmar: Characterization of a New Picorna-Like Virus Isolated From Aphids; J. Gen. Virol. 69 (1988) 787-795. DOI: $10.1099 / 0022-1317-69-4-787$

40. Dombrovsky, A. and N. Luria: The Nerium Oleander Aphid Aphis nerii is Tolerant to a Local Isolate of Aphid lethal paralysis virus (ALPV); Virus Genes 46 (2013) 354-361. DOI: 10.1007/s11262-012-0846-2

41. Anthon, E.W.: Evidence for Green Peach Aphid Resistance to Organo-Phosphorous Insecticides; J. Econ. Entomol. 48 (1955) 56-57.

DOI: org/10.1093/jee/48.1.56

42. Silva, A.X., G. Jander, H. Samaniego, J.S. Ramsey, and C.C. Figueroa: Insecticide Resistance Mechanisms in the Green Peach Aphid Myzus persicae (Hemiptera: Aphididae) I: A Transcriptomic Survey; PLoS ONE 7 (2012) e36366.

DOI: 10.1371/journal.pone.0036366

43. Crumb, S.E.: Tobacco Cutworms; Technical Bulletin No. 88, United States Department of Agriculture, Washington, DC, USA, 1929.

44. Rings, R.W., F.J. Arnold, A.J. Keaster, and G.J. Musick: A Worldwide, Annotated Bibliography of the Black Cutworm, Agrotis ipsilon (Hufnagel); Research Circular No. 198, Ohio Agricultural Research and Development Center, Wooster, $\mathrm{OH}$, USA, 1974.

45. Gholson, L.E.: The Attraction of Agrotis ipsilon (Hufnagel) Larvae to Baits; Dissertation at the Iowa State University, Ames, IA, USA, 1978, available at: https://lib.dr.iastate.edu/cgi/viewcontent.cgi?article $=7547 \&$ context $=$ rtd. (Accessed August 2018).

46. Gurney, W.B.: Insect Pests of Cotton in New South Wales; Agric. Gaz. N.S.W. 34 (1924) 887-893.

47. Liu, K.: Life History and Control Measures of Aqrotis ypsilon in Hangchow [Chinese]; Yearbook, Bureau of Entomology, Hangchow 5 (1936) 71-81.

48. Kuwayama, S., K. Sakurai, and K. Endo: Soil Insects in Hokkaido, Japan, with Special Reference to the Effects of Some Chlorinated Hydrocarbons; J. Econ. Entomol. 53 (1960) 1015-1018. DOI: $10.1093 /$ jee/53.6.1015

49. Oku, T. and T. Kobayashi: Studies on the Ecology and Control of Insects in Grasslands. V. Oviposition Behaviour of the Black Cutworm Moth, Agrotis ypsilon Hufnagel, with Notes on Some Larval Behaviours; Bull. Tohoku Natl. Agric. Exp. Stn, 46 (1973) 161-183.

50. Potter, D.A.: Destructive Turfgrass Insects: Biology, Diagnosis, and Control; John Wiley \& Sons, New York, NY, USA, 1998.

51. Fernandes, F.L., J.F.S. Diniz, P.R. Silva, and E. 
Mosca: Damage of Agrotis ipsilon (Lepidoptera: Noctuidae) on Coffea arabica in Brazil; Rev. Colomb. Entomol. 39 (2013) 49-50.

52. Valencia, L. and R. Valdivia: Noctuideos del Valle de Ica, sus plantas hospederas y enemigos naturales; Rev. Peruana Entomol. 16 (1973) 94-101.

53. Kirti, J.S. and M.A. Dar: Keys for the Identification and Segregation of Noctuid Subfamilies; Insect Environ. 19 (2013) 176-179.

54. Hampson, G.: The Fauna of British India, Including Ceylon and Burma. Moths, Volume II; Taylor and Francis, London, UK, 1894.

55. Walkden, H.H.: Cutworms, Armyworms and Related Species Attacking Cereal and Forage Crops in the Central Great Plains; United States Department of Agriculture, Washington, DC, USA, Circular No. $849,1950$.

56. Satterthwait, A.F.: Larval Instars and the Feeding of the Black Ccutworm, Agrotis ypsilon Rott; J. Agric. Res. 46 (1933) 517-530.

57. Clement, S.L. and D.A. McCartney: Black Cutworm (Lepidoptera: Noctuidae): Measurement of Larval Feeding Parameters on Field Corn in the Greenhouse; J. Econ. Entomol. 75 (1982) 1005-1008.

DOI: $10.1093 /$ jee/75.6.1005

58. Williamson, C.R. and D.A. Potier: Oviposition of Black Cutworm (Lepidoptera: Noctuidae) on Creeping Bentgrass Putting Greens and Removal of Eggs by Mowing; J. Econ. Entomol. 90 (1997) 590-594. DOI: 10.1093/jee/90.2.590

59. Cook, W.C.: Cutworm and Armyworms; Office State Entomologist Minnesota Circular 52 (1920) 8.

60. Maxwell-Lefroy, H. and C.C. Ghosh: The Indian Surface Caterpillars of the Genus "Agrotis"; Memoirs of the Department of Agriculture in India, Entomology Series 1, 1907.

61. Mangat, B.: Development of the Black Cutworm; J. Econ. Entomol. 64 (1971) 766.

62. Reese, J.C., L.M. English, T.R. Yonke, and M.L. Fairchild: A Method for Rearing Black Cutworms; J. Econ. Entomol. 65 (1972) 1047-1050.

DOI: $10.1093 /$ jee/65.4.1047

63. Allan, D.J.: Rearing Agrotis ypsilon (Lepidoptera: Noctuidae) for Parasite Release; N. Z. Entomol. 5 (1973) 274-277.

DOI: $10.1080 / 00779962.1973 .9723021$

64. Showers, W.B., R.B. Smelser, A.J. Keaster, F. Whitford, J.F. Robinson, J.D. Lopez, and S.E. Taylor: Recapture of Marked Black Cutworm (Lepidoptera: Noctuidae) Males after Long-Range Transport; Environ. Entomol. 18 (1989) 447-458.

DOI: $10.1093 / \mathrm{ee} / 18.3 .447$

65. Showers, W.B., A.J. Keaster, J.R. Raulston, W.H. Hendrix, M.E. Derrick, M.D. McCorcle, J.F. Robinson, M.O. Way, M.J. Wallendorf, and J.L. Goodenough: Mechanism of Southward Migration of a Noctuid Moth [Agrotis ipsilon (Hufnagel)]: A Complete Migrant; Ecology 74 (1993) 2303-2314. DOI: $10.2307 / 1939583$

66. Bretherton, R.F.: On Rearing Agrotis ipsilon Hufnagel. (The Dark Sword-Grass) (Lepidoptera, Noctuidae); Entomol. Gaz. 20 (1969) 83-85.
67. Odiyo, P.O.: Seasonal Distribution and Migrations of Agrotis ipsilon (Hufnagel) (Lepidoptera, Noctuidae); Tropical Pest Bulletin 4, Centre for Overseas Pest Research (COPR), London, UK, 1975.

68. Rivnay, E. and S. Yathom: Phenology of Agrotinae in Israel; Z. Angew. Entomol. 55 (1964) 136-152. DOI: $10.1111 /$ j.1439-0418.1964.tb02972.x

69. Carey, J.R. and C.C. Beegle: Black Cutworm Overwintering Investigations in Infested Screenhouses; Proc. North-Central Branch Entomol. Soc. Am. 30 (1975) 59-65.

70. Quaintance, A.L.: A Preliminary Report on the Insect Enemies of Tobacco in Florida; Bulletin No. 48, Florida Agricultural Experiment Station, E.O. Painter \& Co., Deland, FL, USA, 1898.

71. Whitworth, R.J. and H. Davis: Kansas Crop Pests: Black Cutworm; Kansas State University Agricultural Experiment Station and Cooperative Extension Service, Publication No. MF-2954, 2011.

72. Troester, S.J., W.G. Ruesink, and R.W. Rings: A Model of Black Cutworm (Agrotis ipsilon) Development: Description Uses, And Implications; Agricultural Experiment Station, University of Illinois at Urbana-Champaign, Bulletin 774, 1982.

73. Hill, A.S., R.W. Rings, S.R. Swier, and W.L. Roelofs: Sex Pheromone Of The Black Cutworm Moth, Agrotis ipsilon; J. Chem. Ecol. 5 (1979) 439-457. DOI: 10.1007/BF00987929

74. Swier, S.R., R.W. Rings, and G.J. Musick: Reproductive Behavior of the Black Cutworm, Agrotis ipsilon; Ann. Entomol. Soc. Am. 69 (1976) 546-550. DOI: 10.1093/aesa/69.3.546

75. Swier, S.R., R.W. Rings, and G.J. Musick: AgeRelated Calling Behavior of the Black Cutworm, Agrotis ipsilon; Ann. Entomol. Soc. Am. 70 (1977) 919-924. DOI: 10.1093/aesa/70.6.919

76. Abdel-Gawaad, A.A. and A.Y. El-Shazli: Studies on the Common Cutworm Agrotis ypsilon Rott. 1. Life Cycle and Habits; Z. Angew. Entomol. 68 (1971) 409-412. DOI: 10.1111/j.1439-0418.1971.tb03170.x

77. Luckmann, W.H., J.T. Shaw, D.W. Sherrod, and W.G. Ruesink: Developmental Rate of the Black Cutworm; J. Econ. Entomol. 69 (1976) 386-388. DOI: $10.1093 /$ jee/69.3.386

78. Blair, B.W.: Seasonal Abundance of Agrotis segetum (Denis \& Schiff.) and A. ipsilon (Hüfn.) (Lepidoptera: Noctuidae) in Zimbabwe and a Method of Forecasting Post-Winter Population Densities; J. Entomol. Soc. Southern Africa 45 (1982) 201-215.

79. Cook, W.C.: Cutworms and Armyworms; Agricultural Experiment Station Circular No. 48, University of Minnesota, 1934, pp. 1-8.

80. Crumb, S.E.: The Larvae of the Phalaenidae, Technical Bulletin No. 1135, United States Department of Agriculture, Washington, DC, USA, 1956.

81. Canadian Tobacco Research Foundation (CTRF): Scouting for Cutworms, Aphids, and Hornworms; available at: http://ctrf1.com/2016/06/scouting-forcutworms-aphids-and-hornworms/. (Accessed September 2018).

82. Chamberlin, F.S. and N. Allen: Tobacco Cutworms: How to Control Them; Leaflet No. 417, United States 
Department of Agriculture, Washington, DC, USA, 1957.

83. Ebssa, L. and A.M. Koppenhöfer: Entomopathogenic Nematodes for the Management of Agrotis ipsilon: Effect of Instar, Nematode Species and Nematode Production Method; Pest Manag. Sci. 68 (2012) 947-957. DOI: 10.1002/ps.3259

84. Cossentine, J.E. and L.C. Lewis: Interactions Between Vairimorpha necatrix, Vairimorpha sp., and a Nuclear Polyhedrosis Virus From Rachiplusia ou in Agrotis ipsilon Larvae; J. Invertebrate Pathol. 44 (1984) 28-35.

DOI: org/10.1016/0022-2011(84)90042-9

85. Boughton, A.J., R.L. Harrison, L.C. Lewis, and B.C. Bonning: Characterization of a Nucleopolyhedrovirus From the Black Cutworm, Agrotis ipsilon (Lepidoptera: Noctuidae); J. Invertebrate Pathol. 74 (1999) 289-294. DOI: org/10.1006/jipa.1999.4901

86. Zethner, O., B.M. Khan, M.I. Chaudhry, B. Bolet, S. Khan, H. Khan, H. Gul, L. Øgaard, M. Zaman, and G. Nawaz: Agrotis segetum Granulosis Virus as a Control Agent Against Field Populations of Agrotis ipsilon and A. segetum [Lep.: Noctuidae] on Tobacco, Okra, Potato and Sugar Beet in Northern Pakistan; Entomophaga 32 (1987) 449-455.

DOI: org/10.1007/BF02373513

87. Bixby-Brosi, A.J. and D.A. Potter: Evaluating a Naturally Occurring Baculovirus for Extended Biological Control of the Black Cutworm (Lepidoptera: Noctuidae) in Golf Course Habitats; J. Econ. Entomol. 103 (2010) 1555-1563.

DOI: org/10.1603/EC10171

88. Gabarty, A., H.M. Salem, M.A. Fouda, A.A. Abas, and A.A. Ibrahim: Pathogencity Induced by the Entomopathogenic Fungi Beauveria bassiana and Metarhizium anisopliae in Agrotis ipsilon (Hufn.); Journal of Radiation Research and Applied Sciences 7 (2014) 95-100.

DOI: org/10.1016/j.jrras.2013.12.004

89. Salamov, T.S.: Ichneumonids as Parasites of Agrotis segetum; Zashchita Rastenii 4 (1974) 1-34.

90. Herting, B.: A Critical Revision of Host Records of Palearctic Tachinidae (Diptera) until 1937; Stuttgarter Beitr. Naturk. A, Neue Serie 10 (2017) 41-173. DOI: org/10.18476/sbna.v10.a3

91. Patel, A.G., D.N. Yadav, and R.C. Patel: Natural Enemies of Agrotis spp. From Gujarat; Gujarat Agric. Univ. Res. J. 17 (199) 130-131.

92. CABI: Invasive species compendium: Agrotis ipsilon (Black Cutworm); available at: https://www.cabi.org/ isc/datasheet/3801. (Accessed September 07, 2018).

93. Begg, J.A., C.R. Harris, and G.F. Manson: Chemical Control of Artificial Infestations of the Black Cutworm, Agrotis ipsilon, in Flue-Cured Tobacco; Can. J. Plant Sci. 43 (1963) 30-37.

DOI: $10.4141 /$ cjps63-005

94. Madden, A.H. and F.S. Chamberlin: Biology of the Tobacco Hornworm in the Southern Cigar-Tobacco District, Technical Bulletin No. 896, United States Department of Agriculture, Washington, DC, USA, 1945.

95. Gilmore, J.U.: Observations on the Hornworms
Attacking Tobacco in Tennessee and Kentucky; J. Econ. Entomol. 31 (1938) 706-712.

DOI: $10.1093 /$ jee/31.6.706

96. Messenger, C.: The Sphinx Moths (Lepidoptera: Sphingidae) of Nebraska; Trans. Nebraska Acad. Sci. 24 (1997) 89-141.

97. Morgan, A.C.: Methods of Controlling Tobacco Insects; U.S. Bureau of Entomology, Circular No. 123, United States Department of Agriculture, Washington, DC, USA, 1910.

98. Svec, H.J.: Laboratory Rearing of the Tomato Hornworm, Protoparce quinquemaculata (Haworth); Can. J. Zool. 42 (1964) 717. DOI: 10.1139/z64-065

99. Banham, F.L.: Notes on Diapause in the Tomato Hornworm (Lepidoptera: Sphingidae), in British Columbia; J. Entomol. Soc. British Columbia 67 (1970) 16-17.

100. Madden, A.H. and F.S. Chamberlin: Biological Studies of the Tomato Worm on Tobacco in Florida, 1936 and 1937; J. Econ. Entomol. 31 (1938) 703-706. DOI: 10.1093/jee/31.6.703

101. Sasaki, M. and L.M. Riddiford: Regulation of Reproductive Behaviour and Egg Maturation in the Tobacco Hawk Moth, Manduca sexta; Physiol. Entomol. 9 (1984) 315-327. DOI: $10.1111 /$ j.1365-3032.1984.tb00713.x

102. Starratt, A.N., K.H. Dahm, N. Allen, J.G. Hildebrand, T.L. Payne, and H. Röller: Bombykal, a Sex Pheromone of the Sphinx Moth Manduca sexta; Z. Naturforsch. C 34 (1979) 9-12.

DOI: $10.1515 /$ znc-1979-1-206

103. Tumlinson, J.H., M.M. Brennan, R.E. Doolittle, E.R. Mitchell, A. Brabham, B.E. Mazomenos, A.H. Baumhover, and D.M. Jackson: Identification of a Pheromone Blend Attractive to Manduca sexta (L.) Males in a Wind Tunnel; Arch. Insect Biochem. Physiol. 10 (1989) 255-271.

DOI: $10.1002 /$ arch. 940100402

104. Kalinová, B., M. Hoskovec, I. Liblikas, C.R. Unelius, and B.S. Hansson: Detection of Sex Pheromone Components in Manduca sexta (L.); Chem. Senses 26 (2001) 1175-1186. DOI: 10.1093/chemse/26.9.1175

105. Stehr, F.W.: Immature Insects, Volumes 1-2, Kendall/Hunt Publishing Company, Dubuque, IA, USA, 1987.

106. Reinecke, J.P., J.S. Buckner, and S.R. Grugel: Life Cycle of Labratory-Reared Tobacco Hornworms, Manduca Exta, a Study of Development and Behavior, Using Time-Lapse Cinematography; Biol. Bull. 158 (1980) 129-140. DOI: 10.2307/1540764

107. Semtner, P.J.: Tobacco Insect Management; in: 2012 Flue-Cured Tobacco Production Guide, Virginia Cooperative Extension, Virginia Tech, VA, USA, 2012, pp. 75-102, available at: https://pubs.ext.vt. edu/content/dam/pubs_ext_vt_edu/AREC/AREC-14/ AREC-14-pdf.pdf. (Accessed September 2018)

108. Snow, J.W., D.G. Haile, A.H. Baumhover, W.W. Cantelo, J.L. Goodenough, J.M. Stanley, and T.J. Henneberry: Control of the Tobacco Hornworm on St. Croix, U.S. Virgin Islands, by the Sterile Male Technique; Agricultural Research Service, Publication No. S-98, United States Department of 
Agriculture, Washington, DC, USA, 1976.

109. White, G.F.: Hornworm Septicemia; J. Agric. Res. 26 (1923) 477-486.

110. Rabb, R.L.: Biology of Conoderus vespertinus in the Piedmont Section of North Carolina (Coleoptera: Elateridae); Ann. Entomol. Soc. Am. 56 (1963) 669-676. DOI: 10.1093/aesa/56.5.669

111. Zitani, N.M. and S.R. Shaw: From Meteors to Death Stars: Variations on a Silk Thread (Hymenoptera: Braconidae: Meteorinae); Am. Entomol. 48 (2002) 228-235. DOI: 10.1093/ae/48.4.228

112. Puttler, B.: Biology of Hyposoter exiguae (Hymenoptera: Ichneumonidae), A Parasite of Lepidopterous Larvae; Ann. Entomol. Soc. Am. 54 (1961) 25-30. DOI: 10.1093/aesa/54.1.25

113. Blanco, C.A., A.P. Terán-Vargas, J.D. López, J.V. Kauffman, and X. Wei: Densities of Heliothis virescens and Helicoverpa zea (Lepidoptera: Noctuidae) in Three Plant Hosts; Fla. Entomol. 90 (2007) 742-750.

114. Begemann, G.J. and A.S. Schoeman: The Phenology of Helicoverpa armigera (Hübner) (Lepidoptera: Noctuidae), Tortrix capensana (Walker) and Cryptophlebia leucotreta (Meyrick) (Lepidoptera: Tortricidae) on Citrus at Zebediela, South Africa; Afr. Entomol. 7 (1999) 131-148.

115. Neunzig, H.H.: The Eggs and Early-Instar Larvae of Heliothis zea and Heliothis virescens (Lepidoptera: Noctuidae); Ann. Entomol. Soc. Am. 57 (1964) 98-102. DOI: 10.1093/aesa/57.1.98

116. Tay, W.T., M.F. Soria, T. Walsh, D. Thomazoni, P. Silvie, G.T. Behere, C. Anderson, and S. Downes: A Brave New World for An Old World Pest: Helicoverpa armigera (Lepidoptera: Noctuidae) in Brazil; PLoS ONE 8 (2013) e80134.

DOI: 10.1371/journal.pone.0080134

117. Murúa, M.G., F.S. Scalora, F.R. Navarro, L.E. Cazado, A. Casmuz, M.E. Villagrán, E. Lobos, and G. Gastaminza: First Record of Helicoverpa armigera (Lepidoptera: Noctuidae) in Argentina; Fla. Entomol. 97 (2014) 854-856.

DOI: $10.1653 / 024.097 .0279$

118. Hardwick, D.F.: The Corn Earworm Complex; Mem. Entomol. Soc. Can. 97 (1965) 5-247.

DOI: $10.4039 / \mathrm{entm} 9740 \mathrm{fv}$

119. Hardwick, D.F.: A Generic Revision of the North American Heliothidinae (Lepidoptera: Noctuidae); Mem. Entomol. Soc. Can. 102 (1970) 5-59. DOI: $10.4039 /$ entm10273fv

120. Common, I.F.B.: A New Australian Species of Heliothis Ochsenheimer (Lepidoptera: Noctuidae); J. Aust. Ent. Soc. 24 (1985) 129-133. DOI: $10.1111 / \mathrm{j} .1440-6055.1985 . t b 00208 . x$

121. Tood, E.L.: The Distribution and Nomenclature of the Corn Earworm; J. Econ. Entomol. 48 (1955) 600-603. DOI: 10.1093/jee/48.5.600

122. Pearson, E.O.: Insect Pests of Cotton in Tropical Africa; Empire Cotton Growing Corporation and Commonwealth Institute of Entomology, London, UK, 1958.

123. Forbes, W.T.M.: Lepidoptera of New York and Neighboring States. Part III. Noctuidae; Agric. Exp.
Station Mem. 329, Cornell University, ???,1954.

124. Kirkpatrick, T.H.: Comparative Morphological Studies of Heliothis Species (Lepidoptera: Noctuidae) in Queensland; Queensland J. Agric. Sci. 18 (1961) 179-194.

125. Singh, S.P.: The Proper Name of the Corn Earworm, Heliothis armigera Huebner (Lepidoptera, Noctuidae); Entomol. Rev. 50 (1971) 93-94.

126. Sarwar, Z.M., M. Razaq, S.A. Shad, W. Jaleel, S.A.H. Rizvi, and M.F. Khalid: Taxonomic Studies of Genus Helicoverpa Hardwick with New Record of Helicoverpa zea (Boddie) (Lepidoptera: Noctuidae) from Pakistan; J. Entomol. Zool. Stud. 5 (2017) 565-567.

127. Liu, Z., Y. Xin, Y. Zhang, J. Fan, and J. Sun: Summer Diapause Induced by High Temperatures in the Oriental Tobacco Budworm: Ecological Adaptation to Hot Summers; Sci. Rep. 6 (2016) 27443. DOI: $10.1038 /$ srep27443

128. Li, H., H. Zhang, R. Guan, and X. Miao: Identification of Differential Expression Genes Associated with Host Selection and Adaptation Between Two Sibling Insect Species by Transcriptional Profile Analysis; BMC Genomics 14 (2013) 582. DOI: 10.1186/1471-2164-14-582

129. Ranjith, M.T.: Identification of Larval Morphotypes of Helicoverpa Armigera (Hübner) (Lepidoptera: noctuidae) and Their Characterization Using Molecular Markers; Dissertation, College of Horticulture, Vellanikara, Kerala Agricultural University, Kerala, India, 2015.

130. Amate, J., P. Barranco, and T. Cabello: Identificación de Larvas de las Principales Especies de Noctuidos Plaga de España (Lepidoptera: Noctuidae); Bol. San. Veg. Plagas 24 (1998) 101-106.

131. Li, Q., M. Li, D. Li, W. Shi, J. Li, T. Ning, and Y. Duan: Identification of the Larvae of Helicoverpa assulta and H. Armigera (Lepidoptera: Noctuidae) Through Morphological Difference and DNA Barcoding; 3rd International Conference on Smart Materials and Nanotechnology in Engineering, 2016, pp. 306-309. DOI: 10.12783/dtmse/smne2016/10609

132. Allen, N. and F. Lawson: The Tobacco Budworm ... How to Control It; Farmers' Bulletin No. 2174, U.S. Department of Agriculture, Washington, DC, USA, 1962.

133. Morgan, A.C. and F.S. Chamberlin: The Tobacco Budworm and its Control in the Georgia and Florida Tobacco-Growing Region; Farmers' Bulletin No. 1531, U.S. Department of Agriculture, Washington, DC, USA, 1927.

134. Hackett, D.S. and A.G. Gatehouse: Diapause in Heliothis armigera (Hübner) and $H$. fletcheri (Hardwick) (Lepidoptera: Noctuidae) in the Sudan Gezira; Bull. Entomol. Res. 72 (1982) 409-422. DOI: $10.1017 / \mathrm{S} 0007485300013584$

135. Patel, R.S., K.A. Patel, K.S. Patil, and N.R. Toke: Biology of Helicoverpa armigera Hub. on Rose in Laboratory Condition; Pest Manage. Hortic. Ecosyst. 17 (2011) 144-148.

136. Nakazawa, K., Y. Kimura, and A. Hosoda: Lepidopterous Pests Control in Peppers with Special Refe- 
rence to the Biology of the Oriental Tobacco Budworm, Helicoverpa assulta assulta (Guenee) (Lepidoptera: Noctuidae); Hiroshima Agric. Exp. Station Bull. 30 (1971) 53-76.

137. Nandihalli, B.S. and J.H. Lee: Effect of Host Food Plants on the Biology of the Host, Helicoverpa assulta (Guenée), and its Parasitoid, Campoletis chlorideae Uchida; Adv. Agric. Res. India 3 (1995) 22-32.

138. Wang, K.-Y., Y. Zhang, H.-Y. Wang, X.-M. Xia, and T.-X. Liu: Biology and Life Table Studies of the Oriental Tobacco Budworm, Helicoverpa assulta (Lepidoptera: Noctuidae), Influenced by Different Larval Diets; Insect Sci. 15 (2008) 569-576.

DOI: $10.1111 / \mathrm{j} .1744-7917.2008 .00247 . \mathrm{x}$

139. Brazzel, J.R., L.D. Newsom, J.S. Roussel, C. Lincoln, R.J. Williams, and G. Barnes: Bollworm and Tobacco Budworm as Cotton Pests in Louisiana and Arkansas; LSU Agricultural Experiment Station Reports. 51, Bulletin No. 482, Louisiana Tech, USA, 1953, available at: http://digitalcommons.lsu.edu/agexp/51 . (Accessed September 2018)

140. Lincoln, C., J.R. Phillips, W.H. Whitcomb, G.C. Dowell, W.P. Boyer, K.O. Bell Jr, G.L. Dean, E.J. Matthews, J.B. Graves, L.D. Newsom, D.F. Clover, J.R. Bradley, Jr, and J.L. Bagent: The BollwormTobacco Budworm Problem in Arkansas and Louisiana; Louisiana Agricultural Experiment Station, Bulletin No. 720, Louisiana Tech, USA, 1967.

141. Neunzig, H.H.: Biology of the Tobacco Budworm and the Corn Earworm in North Carolina: With Particular Reference to Tobacco as a Host; North Carolina Agricultural Experiment Station, Tech. Bull. 196, Raleigh, NC, USA, 1969.

142. Fye, R.E. and W.C. McAda: Laboratory Studies on the Development, Longevity, and Fecundity of Six Lepidopterous Pests of Cotton in Arizona; Technical Bulletin No. 1454, United States Department of Agriculture, Washington, DC, USA, 1972.

143. Butler, G.D. Jr and A.G. Hamilton: Development Time of Heliothis virescens in Relation to Constant Temperature; Environ. Entomol. 5 (1976) 759-760. DOI: $10.1093 /$ ee/5.4.759

144. Tollefson, M.S.: Biology of the Tobacco Budworm, Heliothis virescens (F.) on Irrigated Cotton in Arizona [Master's Thesis]; University of Arizona, Tuscon, AZ, USA, 1979.

145. Ming, Q.-L., Y.-H. Yan, and C.-Z. Wang: Mechanisms of Premating Isolation Between Helicoverpa armigera (Hübner) and Helicoverpa assulta (Guenée) (Lepidoptera: Noctuidae); J. Insect Physiol. 53 (2007) 170-178.

DOI: $10.1016 /$ j.jinsphys.2006.11.007

146. Klun, J.A., B.A. Bierl-Leonhardt, J.R. Plimmer, A.N. Sparks, M. Primiani, O.L. Chapman, G. Lepone, and G.H. Lee: Sex Pheromone Chemistry of the Female Tobacco Budworm Moth, Heliothis virescens; J. Chem. Ecol. 6 (1980) 177-183.

DOI: $10.1007 / \mathrm{BF} 00987536$

147. Tumlinson, J.H., D.E. Hendricks, E.R. Mitchell, R.E. Doolittle, and M.M. Brennan: Isolation, Identification, and Synthesis of the Sex Pheromone of the
Tobacco Budworm; J. Chem. Ecol. 1 (1975) 203-214. DOI: $10.1007 /$ bf00987869

148. Almaas, T.J. and H. Mustaparta: Pheromone Reception in Tobacco Budworm Moth, Heliothis virescens; J. Chem. Ecol. 16 (1990) 1331-1347. DOI: $10.1007 / \mathrm{bf01021030}$

149. Jacobson, M., V.E. Adler, and A.H. Baumhover: A Male Tobacco Budworm Pheromone Inhibitory to Courtship; J. Environ. Sci. Health A: Environ. Sci. Engin. 19 (1984) 469-476.

DOI: $10.1080 / 10934528409375172$

150. Phillips, J.R.: Current Research Aimed at Speeding up Identifying a Bollworm/Tobacco Budworm Infestation; Agri-Fieldman and Consultant 34 (1978) 24

151. Peterson, A.: Larvae of Insects, Part 1; Edwards Brothers, Ann Arbor, MI, USA, 1948.

152. Neunzig, H.H.: The Pupae of Heliothis zea and Heliothis virescens (Lepidoptera: Noctuidae); Ann. Entomol. Soc. Am. 53 (1960) 551-552. DOI: $10.1093 / \mathrm{aesa} / 53.4 .551$

153. Phillips, J.R. and L.D. Newsom: Diapause in Heliothis zea and Heliothis virescens (Lepidoptera: Noctuidae); Ann. Entomol. Soc. Am. 59 (1966) 154-159. DOI: 10.1093/aesa/59.1.154

154. Nel, J.J.C.: The Seasonal History of Heliothis armigera (Hub.) on Lupins in the South Western Cape Province; S. Afric. J. Agric. Sci. 4 (1961) 575-588.

155. Juba, T.R., J.R. Bradley Jr, A. Notz, P.S. Southern, and C.E. Sorenson: Effect of Tobacco Budworm (Lepidoptera: Noctuidae) Infestation Level on Budworm-Resistant and -Susceptible Varieties of Flue-Cured Tobacco in North Carolina; J. Econ. Entomol. 100 (2007) 801-807. DOI: $10.1093 /$ jee/100.3.801

156. Romeis, J. and T.G. Shanower: Arthropod Natural Enemies of Helicoverpa armigera (Hübner) (Lepidoptera: Noctuidae) in India; Biocontrol Sci. Technol. 6 (1996) 481-508. DOI: 10.1080/09583159631136

157. Kogan, M., C.G. Helm, J. Kogan, and E. Brewer: Distribution and Economic Importance of Heliothis virescens and Heliothis zea in North, Central and South America Including a Listing and Assessment of the Importance of Their Natural Enemies; in: Proceedings of the Workshop on Biological Control of Heliothis: Increasing the Effectiveness of Natural Enemies, edited by E.G. King, and R.D. Jackson, Far Eastern Regional Research Office, United States Department of Agriculture, New Delhi, India, 1989, pp. 241-297.

158. Watson, T.F., R.T. Gudauskas, and T.D. Canerday.: Parasites, Pathogens and Predators of Some Lepidopterous Pests in Alabama; Agricultural Experiment Station, Zoology-Entomology Department Series 1, 1-3, Auburn, AL, USA, 1966.

159. Roach, S.H.: Heliothis spp. and Their Parasites and Diseases on Crops in the Pee Dee Region of South Carolina, 1971-73; Agricultural Research Services Publication, ARS-S-111, U.S. Department of Agriculture, Washington, DC, USA, 1976.

160. King, E.G., J.E. Powell, and J.W. Smith.: Prospects for Utilization of Parasites and Predators for Management of Heliothis spp.; in: Proc. Int. 
Workshop on Heliothis Management, edited by W. Reed and V. Kumble, ICRISAT Center, Patancheru, India, 15-20 November 1981, 1982, pp.103-122.

161. Tillman, P.G., E.L. Styer, and J.J. Hamm: Transmission of Ascovirus from Heliothis virescens (Lepidoptera: Noctuidae) by Three Parasitoids and Effects of Virus on Survival of Parasitoid Cardiochiles nigriceps (Hymenoptera: Braconidae); Environ. Entomol. 33 (2004) 633-643. DOI: $10.1603 / 0046-225 X-33.3 .633$

162. Elzen, G.W., S.H. Martin, B.R. Leonard, and J.B. Graves: Inheritance, Stability, and Reversion of Insecticide Resistance in Tobacco Budworm (Lepidoptera: Noctuidae) Field Populations; J. Econ. Entomol. 87 (1994) 551-558.

DOI: $10.1093 /$ jee/87.3.551

163. Orlova-Bienkowskaja, M.J.: First Record of the Tobacco Flea Beetle Epitrix hirtipennis Melsheimer [Coleoptera: Chrysomelidae: Alticinae] in Russia; EPPO Bulletin 44 (2014) 44-46.

DOI: $10.1111 /$ epp.12092

164. Metcalf, Z.P. and G.W. Underhill: The Tobacco Flea Beetle; Bulletin No. 239, North Carolina Agricultural Experimentation Station, 1919.

165. Deczynski, A.M.: Morphological Systematics of the Nightshade Flea Beetles Epitrix foudras and Acallepitrix bechyné (Coleoptera: Chrysomelidae: Galerucinae: Alticini) in America North of Mexico [Master's Thesis]; Department of Entomology, Clemson University, Clemson, SC, USA, 2016.

166. Jewett, H.H.: The Tobacco Flea Beetle; Bulletin No. 266, Kentucky Agricultural Experiment Station, Lexington, KY, USA, 1926, pp. 51-66.

167. Gui, H.L.: Potato Flea Beetles and Their Control; Bulletin 595, Ohio Agricultural Experimental Station, Wooster, OH, USA, 1938.

168. Dominick, C.B.: The Biology of the Tobacco Flea Beetle, Epitrix parvula (Coleoptera: Chrysomelidae) in Virginia [Master's Thesis]; Virginia Polytechnic Institute, Blacksburg, VA, USA, 1939.

169. Chamberlin, F.S., J.N. Tenhet, and A.G. Böving: Life-History Studies of the Tobacco Flea-Beetle in the Southern Cigar-Wrapper District; J. Agric. Res. 29 (1924) 575-584.

170. Zilkowski, B.W., R.J. Bartelt, and K. Vermillion: Analysis of 2,4,6-Nonatrienal Geometrical Isomers From Male Flea Beetles, Epitrix hirtipennis and E. fuscula; J. Agric. Food Chem. 56 (2008) 4982-4986. DOI: $10.1021 /$ jf8005273

171. Semtner, P.L.: Effect of Early-Season Infestations of the Tobacco Flea Beetle (Coleoptera: Chrysomelidae) on the Growth and Yield of Flue-Cured Tobacco; J. Econ. Entomol. 77 (1984) 98-102.

DOI: $10.1093 /$ jee/77.1.98

172. Department of Agriculture, Forestry and Fisheries (DAFF): Tobacco Production Guideline; Department of Agriculture, Forestry and Fisheries, Republic of South Africa, Pretoria, South Africa, 2015.

173. Duke, M.E. and E.P. Lampert: Sampling Procedures for Tobacco Flea Beetles (Coleoptera: Chrysomelidae) in Flue-Cured Tobacco; J. Econ. Entomol. 80 (1987) 81-85. DOI: 10.1093/jee/80.1.81
174. Chittenden, F.H.: The Tobacco Flea Beetle; Bureau of Entomology (New Series) No. 19, U.S. Department of Agriculture, Bureau of Entomology, Washington, DC, USA, 1899, pp. 85-90.

175. Elsey, K.D. and J.M. Pitts: Parasitism of the Tobacco Flea Beetle by a Sphaerulariid Nematode Howardula sp.; Environ. Entomol. 5 (1976) 707-711.

DOI: $10.1093 /$ ee/5.4.707

176. Bunn, B., D. Alston, and M. Murray: Flea Beetles on Vegetables (Coleoptera: Chrysomelidae); Utah Pests Fact Sheet, Utah State University Extension Publication ENT-174-15, Logan, UT, USA, 2015; available at: https://utahpests.usu.edu/uppdl/files-ou/ factsheet/flea-beetles.pdf. (Accessed June 12, 2018).

177. Watson, J.R.: Synopsis and Catalog of the Thysanoptera of North America, with a Translation of Karny's Keys to the Genera of Thysanoptera and a Bibliography of Recent Publications; Technical Bulletin No. 168, University of Florida, Agricultural Experiment Station, Gainesville, FL, USA, 1923.

178. Chamberlin, J.R., J.W. Todd, R.J. Beshear, A.K. Culbreath, and J.W. Demski: Overwintering Hosts and Wingform of Thrips, Frankliniella spp., in Georgia (Thysanoptera: Thripidae): Implications for Management of Spotted Wilt Disease; Environ. Entomol. 21 (1992) 121-128.

DOI: $10.1093 / \mathrm{ee} / 21.1 .121$

179. Hinds, W.E.: A New Tobacco Thrips; Proc. Biol. Soc. Washington 18 (1905) 197-200.

180. Eddy, C.O. and E.M. Livingstone: Frankliniella fusca Hinds (Thrips) on Seedling Cotton; Technical Bulletin No. 271, South Carolina Agricultural Experiment Station, SC, USA, 1931.

181. Newsom, L.D., J.S. Roussel, and C.E. Smith: The Tobacco Thrips: Its Seasonal History and Status as a Cotton Pest; Louisiana Agricultural Experiment Station, Technical Bulletin 474, 1953.

182. Bryan, D.E. and R.F. Smith: The Frankliniella occidentalis (Pergande) Complex in California (Thysanoptera: Thripidae); University of California Publications in Entomology 10 (1956) 350-410.

183. Dimitrov, A. and V. Velickova: Host Plants of Frankliniella occidentalis (Pergande) in Bulgaria; Tobacco 53 (2003) 213-216.

184. Yudin, L.S., J.J. Cho, and W.C. Mitchell: Host Range of Western Flower Thrips, Frankliniella occidentalis (Thysanoptera: Thripidae), with Special Reference to Leucaena glauca; Environ. Entomol. 15 (1986) 1292-1295. DOI: 10.1093/ee/15.6.1292

185. Mound, L.A. and G. Kibby: Thysanoptera: An Identification Guide; CAB International, Oxon, NY, USA, 1998.

186. Mound, L.A. and D.C. Morris: The Insect Order Thysanoptera: Classification Versus Systematics; Zootaxa 1668 (2007) 395-411.

187. Mound, L.A.: Order Thysanoptera Haliday, 1836; Zootaxa 3148 (2011) 201-202.

188. Reitz Stuart, R., Y.-1. Gao, and Z.-r. Lei: Thrips: Pests of Concern to China and the United States; Agric. Sci. China 10 (2011) 867-892. DOI: $10.1016 / \mathrm{S} 1671-2927(11) 60073-4$

189. Masumoto, M.: Key to Genera of the Subfamily 
Thripinae (Thysanoptera: Thripidae) Associated with Japanese Plant Quarantine; Res. Bull. Plant Prot. Japan 46 (2010) 25-59.

190. Mound, L.A. and Y.F. Ng: An Illustrated Key to the Genera of Thripinae (Thysanoptera) from South East Asia; Zootaxa 2265 (2009) 27-47.

191. Mirab-balou, M., K. Minaei, and X.-X. Chen: An Illustrated Key to the Genera of Thripinae (Thysanoptera, Thripidae) from Iran; ZooKeys 317 (2013) 27-52. DOI: 10.3897/zookeys.317.5447

192. Sakimura, K. and K. O'Neill: Frankliniella: Redefinition of Genus and Revision of Minuta Group Species: (Thysanoptera: Thripidae); Technical Bulletin No. 1572, United States Department of Agriculture, Washington, DC, USA, 1979.

193. Wang, C.-L., F.-C. Lin, Y.-C. Chiu, and H.-T. Shih: Species of Frankliniella Trybom (Thysanoptera: Thripidae) from the Asian-Pacific Area; Zoological Studies 49 (2010) 824-838.

194. Mound, L., S. Nakahara, and D.M. Tsuda: Thysanoptera-Terebrantia of the Hawaiian Islands: An Identification Manual; ZooKeys 549 (2016) 71-126. DOI: 10.3897/zookeys.549.6889

195. Hoddle, M.S., L.A. Mound, and D.L. Paris: Thrips of California; CBIT Publishing. Queensland, available at: http://keys.lucidcentral.org/keys/v3/thrips_of california/authors/authors.html (accessed September 2018).

196. Nakao, S., C. Chikamori, S. Okajima, Y. Narai, and T. Murai: A New Record of the Tobacco Thrips Frankliniella fusca (Hinds) (Thysanoptera: Thripidae) from Japan; Appl. Entomol. Zool. 46 (2011) 131-134. DOI: 10.1007/s13355-010-0020-z

197. Johansen, R.M.: The Mexican Frankliniella fusca (Hinds), F. pallida (Uzel) and F. schultzei (Trybom) Species Assemblages, in the "Intonsa group" (Insecta, Thysanoptera: Thripidae); Acta Zool. Mexi. 85 (2002) 51-82.

198. Hinds, W.E.: Contribution to a Monograph of the Insects of the Order Thysanoptera Inhabiting North America; Proc. U.S. Natl. Mus. 26 (1902) 79-242.

199. Hooker, W.A.: Tobacco Thrips - A New and Destructive Enemy of Shade-Grown Tobacco; Bulletin No. 65, U.S. Department of Agriculture, Bureau of Entomology, Washington, DC, USA, 1907.

200. Pergande, T.: Observation on Certain Thripidae; Insect Life, Washington. 7 (1895) 390-391.

201. Kirk, W.D.J. and L.I. Terry: The Spread of the Western Flower Thrips Frankliniella occidentalis (Pergande); Agric. For. Entomol. 5 (2003) 301-310. DOI: 10.1046/j.1461-9563.2003.00192.x

202. Cluever, J.D., H.A. Smith, J.E. Funderburk, and G. Frantz: Western Flower Thrips (Frankliniella occidentalis [Pergande]); Series ENY-883, University of Florida, Institute of Food and Agricultural Sciences Extension, 2015.

203. Watts, J.G.: A Study of the Biology of the Flower Thrips Frankliniella tritici (Fitch) with Special Reference to Cotton, Bulletin No. 306, South Carolina Agricultural Experiment Station, 1936.

204. Wilson, L.T., P.J. Trichilo, and D. Gonzales: Natural Enemies of Spider Mites (Acari: Tetranychidae) on
Cotton: Density Regulation or Casual Association?; Environ. Entomol. 20 (1991) 849-856.

DOI: $10.1093 / \mathrm{ee} / 20.3 .849$

205. Borden, A.D.: The Mouthparts of the Thysanoptera and the Relation of Thrips to the Non-Setting of Certain Fruits and Seeds; J. Econ. Entomol. 8 (1915) 354-360. DOI: 10.1093/jee/8.3.354

206. Peterson, A.: Morphological Studies on the Head and Mouth-Parts of the Thysanoptera; Ann. Entomol. Soc. Am. 8 (1915) 20-66. DOI: 10.1093/aesa/8.1.20

207. Gaines, J.C.: A Preliminary Study of Thrips on Seedling Cotton with Special Reference to the Population, Migration, and Injury; J. Econ. Entomol. 27 (1934) 740-743. DOI: 10.1093/jee/27.4.740

208. Forrester, N.W. and A.G.L. Wilson: Insect Pests of Cotton, Agfact P5.AE. 1, New South Wales Department of Agriculture, Australia, 1988.

209. Lacroix, D.S.: Insect Pests of Growing Tobacco in Connecticut; Bulletin No. 379, Connecticut Agricultural Experiment Station, New Haven, CT, USA, 1935, pp. 88-130.

210. Dublon, I.A.N.: The Aggregation Pheromone of the Western Flower Thrips [Dissertation]; Keele University, Keele, Staffordshire, UK, 2009.

211. Sherwood, J.L., T.L. German, J.W. Moyer, and D.E. Ullman: Tomato Spotted Wilt; The Plant Health Instructor (2003). DOI: 10.1094/PHI-I-2003-0613-02

212. Coutinho, T.A. and S.N. Venter: Pantoea ananatis: An Unconventional Plant Pathogen; Mol. Plant Pathol. 10 (2009) 325-335. DOI: $10.1111 / \mathrm{j} .1364-3703.2009 .00542 . x$

213. Bryan, D.E.: The Frankliniella occidentalis Pergande Complex in California (Thysanotera: Thripidae) [Dissertation]; University of California Press, Berkeley, CA, USA, 1952.

214. Reitz, S.R.: Comparative Bionomics of Frankliniella occidentalis and Frankliniella tritici; Fla. Entomol. 91 (2008) 474-476. DOI: 10.1653/0015-4040(2008) 91[474:CBOFOA]2.0.CO;2

215. Reitz, S.R.: Biology and Ecology of the Western Flower Thrips (Thysanoptera: Thripidae): The Making of a Pest; Fla. Entomol. 92 (2009) 7-13. DOI: 10.1653/024.092.0102

216. Stannard, L.J.: The Thrips, or Thysanoptera, of Illinois; Illinois Natural History Survey, Bulletin 29 (1968) 215-552.

217. Pfrimmer, T.R.: Biology and Control of Thrips Attacking Cotton in the Vicinity of College Station, Texas [Dissertation]; Texas A\&M University, College Station, TX, USA, 1953.

218. Ogol, C.K.: Studies of the Biology of the Legume Bud Thrips Megalurothrips sjostedti (Trybon) (Thysanoptera: Thripidae) and its Resistance by Cowpea (Vigna unguiculata (L.) Walp.) [Master's Thesis]; University of Nairobi, Nairobi, Kenya, 1988.

219. Chang, N.T.: Impacts of Soil Physical Factors on the Pupation of Bean Flower Thrips, Megalurothrips usitatus (Bagtall) (Thysanoptera: Thripidae); Plant Prot. Bull. (Taiwan) 31 (1989) 377-386.

220. Lowry, V.K., J.J.W. Smith Jr, and F.L. Mitchell: Life-Fertility Tables for Frankliniella fusca (Hinds) and F. occidentals (Pergande) (Thysanoptera: 
Thripidae) on Peanut; Ann. Entomol. Soc. Am 85 (1992) 744-754. DOI: 10.1093/aesa/85.6.744

221. Joost, P.H. and D.G. Riley: Sampling Techniques for Thrips (Thysanoptera: Thripidae) in Preflowering Tomato; J. Econ. Entomol. 97 (2004) 1450-1454. DOI: $10.1603 / 0022-0493-97.4 .1450$

222. Wilkinson, W.C., L.R. Fisher, W.D. Smith, and D.L. Jordan: Effects of Stand Loss, Planting Date, and Replanting Method on Yield and Quality of Flue-Cured Tobacco; Tobacco Science 47 (2008) 44-52. DOI: $10.3381 / 1965.1$

223. McPherson, R.M., D.C. Jones, P.F. Bertrand, and A.S. Csinos: Impact of Thrips (Thysanoptera: Thripidae) Management Practices on Suppression of Tomato Spotted Wilt Virus and Aphid (Homoptera: Aphididae) Control on Flue-Cured Tobacco; J. Entomol. Sci. 57 (2002) 143-153. DOI: $10.18474 / 0749-8004-37.2 .143$

224. Potter, D.A. and D.W. Held: Biology and Management of the Japanese Beetle; Annu. Rev. Entomol. 47 (2002) 175-205. DOI: 10.1146/annurev.ento.47.091201.145153

225. Vittum, P.J., M.G. Villani, and H. Tashiro: Turfgrass Insects of the United States and Canada; Comstock Publishing Associates, Ithaka, NY, USA, 1999. ISBN 978-0-8014-3508-9

226. Fleming, W.E.: Biology of the Japanese Beetle; Technical Bulletin No. 1449, United States Department of Agriculture, Washington, DC, USA, 1972.

227. Sarkar, S.K., S. Saha, and D. Raychaudhuri: Taxonomic Account of Popillia Dejean, 1821 (Rutelinae: Scarabaeidae) of Buxa Tiger Reserve (A Forest Under Biodiversity Hot Spot Zone), Dooars, West Bengal, India; J. Entomol. Zool. Stud. 4 (2016) 581-585.

228. Davis, J.J.: The Green Japanese Beetle; Department of Agriculture Circular No. 30, State of New Jersey, Department of Agriculture, 1920.

229. Hawley, I.: Notes on the Biology of the Japanese Beetle, Publication E-615, United States Department of Agriculture, Agricultural Research Administration, Bureau of Entomology and Plant Quarantine, 1944.

230. Régnière, J., R.L. Rabb, and R.E. Stinner: Popillia Japonica: Seasonal History and Associated Scarabaeidae in Eastern North Carolina; Environ. Entomol. 10 (1981) 297-300.

DOI: $10.1093 / \mathrm{ee} / 10.3 .297$

231. Vittum, P.J.: Biology of the Japanese Beetle (Coleoptera: Scarabaeidae) in Eastern Massachusetts; J. Econ. Entomol. 79 (1986) 387-391.

DOI: $10.1093 /$ jee/79.2.387

232. Goonewardene, H.F. and D.B. Zepp: Rearing the Immature Feeding Stages of the Japanese Beetle in Pans; J. Econ. Entomol. 63 (1970) 859-860. DOI: $10.1093 /$ jee/63.3.859

233. Sim, R.J.: Characters Useful in Distinguishing Larvae of Popillia japonica and Other Introduced Scarabaeidae From Native Species; Circular No. 334, United States Department of Agriculture, Washington, DC, USA, 1934.

234. Rodríguez, R.L., M.G. Burger, J.E. Wojcinski, and
J.T. Kilmer: Vibrational Signals and Mating Behavior of Japanese Beetles (Coleoptera: Scarabaeidae); Ann. Entomol. Soc. Am. 108 (2015) 986-992.

DOI: $10.1093 /$ aesa/sav091

235. Barrows, E.M. and G. Gordh: Sexual Behavior in the Japanese Beetle, Popillia japonica, and Comparative Notes on Sexual Behavior of Other Scarabs (Coleoptera: Scarabaeidae); Behav. Biol. 23 (1978) 341-354. DOI: 10.1016/S0091-6773(78)91365-2

236. Ishida, Y. and W.S. Leal: Chiral Discrimination of the Japanese Beetle Sex Pheromone and a Behavioral Antagonist by a Pheromone-Degrading Enzyme; Proc. Natl. Acad. Sci. USA 105 (2008) 9076-9080. DOI: 10.1073 pnas.0802610105

237. Kim, J.Y. and W.S. Leal: Ultrastructure of Pheromone-Detecting Sensillum Placodeum of the Japanese Beetle, Popilliajaponica Newmann (Coleoptera: Scarabaeidae); Arthropod Struct. Dev. 29 (2000) 121-128. DOI: 10.1016/S1467-8039(00)00022-0

238. Smith, L.B.: Larval Food Habits of the Japanese Beetle (Popillia Japonica Newm.); J. Econ. Entomol. 15 (1922) 305-310. DOI: 10.1093/jee/15.4.305

239. Hawley, I.M. and F.W. Metzger: Feeding Habits of the Adult Japanese Beetle, Circular No. 547, United States Department of Agriculture, Washington, DC, USA, 1940.

240. Manley, D.G.: Managing the Japanese Beetle on Tobacco in South Carolina; J.Agric. Entomol. 2 (1985) 398-399.

241. Fleming, W.E.: Biological Control of the Japanese Beetle; Technical Bulletin 1383, United States Department of Agriculture, Washington, DC, USA, 1968.

242. Cappaert, D.L. and D.R. Smitley: Parasitoids and Pathogens of Japanese Beetle (Coleoptera: Scarabaeidae) in Southern Michigan; Environ. Entomol. 31 (2002) 573-580. DOI: 10.1603/0046-225X-31.3.573

243. Hanula, J.L., T.G. Andreadis, and M. Blackwell: Entoderma colletosporium gen. and sp. nov., a Unique Cuticular Fungus Infecting Japanese Beetle, Popillia japonica (Coleoptera: Scarabaeidae); J. Invertebrate Pathology 58 (1991) 327-334. DOI: 10.1016/0022-2011(91)90177-R

244. Petty, B.M., D.T. Johnson, and D.C. Steinkraus: Ovavesicula popilliae (Microsporidia: Ovavesiculidae) Spore Production in Naturally Infected Adult Japanese Beetles (Coleoptera: Scarabaeidae); J. Invertebrate Pathol. 111 (2012) 255-256. DOI: $10.1016 /$ j.jip.2012.08.012

245. Hays, J., R.E. Clopton, D.L. Cappaert, and D.R. Smitley: Revision of the Genus Stictospora and Description of Stictospora villani, n. sp. (Apicomplexa: Eugregarinida: Actinocephalidae) From Larvae of the Japanese Beetle, Popillia japonica (Coleoptera: Scarabaeidae), in Michigan; J. Parasitol. 90 (2004) 1450-1456.

DOI: $10.1645 / \mathrm{GE}-345 \mathrm{R}$

246. Dogger, J.R.: The Elateridae of Wisconsin; Wisconsin Academy of Sciences, Arts and Letters 48 (1959) 103-120.

247. Stibick, J.N.L.: Classification of the Elateridae (Coleoptera). Relationships and Classification of the 
Subfamilies and Tribes; Pacific Insects 20 (1979) 145-186.

248. Van Dyke, E.C.: Miscellaneous Studies in the Elateridae and Related Families of Coleoptera; Proc. Calif. Acad. Sci. 20 (1932) 291-465.

DOI: $10.5962 /$ bhl.part.24287

249. Chamberlin, F.S. and A.H. Madden: Insect Pests of Cigar-Type Tobaccos in the Southern Districts; Circular No. 639, United States Department of Agriculture, Washington, DC, USA, 1942.

250. Creighton, C.S., W.S. Kinard, and N. Allen: The Southern Potato Wireworm, a New Pest of Tobacco; J. Econ. Entomol. 56 (1963) 292-294. DOI: $10.1093 /$ jee/56.3.292

251. Day, A., F.P. Cuthbert Jr, and W.J. Reid Jr: The Southern Potato Wireworm. Its Biology and Economic Importance in Coastal South Carolina; South Carolina Agricultural Experiment Station, Technical Bulletin No. 1443, United States Department of Agriculture, Washington, DC, USA, 1971.

252. Norris, D.M., Jr: Bionomics of the Southern Potato Wireworm, Conoderus falli Lane. 1. Life History in Florida; Proc. Fla. Hortic. Soc. 70 (1957) 109-111.

253. Cockerham, K.L. and O.T. Deen: Notes on Life History, Habits and Distribution of Heteroderes laurentii Guér; J. Econ. Entomol. 29 (1936) 288-296. DOI: $10.1093 /$ jee/29.2.288

254. Stone, M.W. and J. Wilcox: The Gulf Wireworm [Conoderus amplicollis] in California (Coleoptera: Elateridae); Pan-Pacific Entomologist 55 (1979) 235-238.

255. Conradi, A.F. and H.C. Eagerton: The Spotted Click Beetle: (Monocrepidius vespertinus, Fab.), Bulletin No. 179, South Carolina Agricultural Experiment Station, Clemson College, SC, USA, 1914.

256. Turnipseed, S.G.: Some Factors Influencing Oviposition by the Tobacco Wireworm, Conoderus vespertinus (Coleoptera: Elateridae) [Dissertation]; North Carolina State College, Raleigh, NC, USA, 1961.

257. Turnipseed, S.G. and R.L. Rabb: Some Factors Influencing Oviposition by the Tobacco Wireworm, Conoderus vespertinus (Coleoptera: Elateridae); Ann. Entomol. Soc. Am. 56 (1963) 751-755. DOI: $10.1093 /$ aesa/56.6.751

258. Edwards, E.E. and J.R. Evans: Observations on the Biology of Corymbites cupreus F. (Coleoptera, Elateridae); Ann. Appl. Biol. 37 (1950) 249-259. DOI: $10.1111 / \mathrm{j} .1744-7348.1950 . t b 01043 . \mathrm{x}$
259. Kuhar, T.P., and J. Speese, III: Scouting for Wireworms Before Planting Vegetables; Virginia Vegetable, Small Fruit and Specialty Crops 1 (2002) 1-2.

260. Cuthbert Jr, F.P., W.J. Reid Jr, and A. Day: The Southern Potato Wireworm; How to Control it on Irish Potatoes; Farmers' Bulletin, No. 534, United States Department of Agriculture, Washington, DC, USA, 1965.

261. Ward, R.H. and A.J. Keaster: Wireworm Baiting: Use of Solar Energy to Enhance Early Detection of Melanotus depressus, M. verberans, and Aeolus mellillus in Midwest Cornfields; J. Econ. Entomol. 70 (1977) 403-406. DOI: 10.1093/jee/70.4.403

262. Bynum, J.E.D. and T.L. Archer: Wireworm (Coleoptera: Elateridae) Sampling for Semiarid Cropping Systems; J. Econ. Entomol. 80 (1987) 164-168. DOI: $10.1093 /$ jee/80.1.164

263. Tóth, M.: Pheromones and Attractants of Click Beetles: An Overview; J. Pest Sci. 86 (2013) 3-17. DOI: $10.1007 / \mathrm{s} 10340-012-0429-\mathrm{y}$

264. Traugott, M., C.M. Benefer, R.P. Blackshaw, W.G. van Herk, and R.S. Vernon: Biology, Ecology, and Control of Elaterid Beetles in Agricultural Land; Annu. Rev. Entomol. 60 (2015) 313-334. DOI: 10.1146/annurev-ento-010814-021035

265. Garman, H. And H.H. Jewett: The broods of the tobacco worms; Kentucky Agricultural Experiment Station, Research Bulletin Number 225, University of Kentucky, Lexington, KY, USA, 1920.

266. Tuttle, D.M.: Thrips of economic importance in Arizona; Progressive Agriculture in Arizona 18 (1966) 10-11.

Corresponding author:

Peter A. Edde

Altria Client Services LLC

Research Development and Engineering

601 East Jackson Street

Richmond, VA 23219, USA

E-mail:Peter.A.Edde@Altria.com or Peter.Edde@Okstate.Edu 